\title{
Size fractionation, chemotaxonomic groups and bio-optical properties of phytoplankton along a transect from the Mediterranean Sea to the SW Atlantic Ocean
}

\author{
Sdena Nunes ${ }^{1}$, Gonzalo Luís Perez ${ }^{2}$, Mikel Latasa ${ }^{3}$, Marina Zamanillo ${ }^{1}$, Maximino Delgado ${ }^{1}$, \\ Eva Ortega-Retuerta ${ }^{1,4}$, Celia Marrasé ${ }^{1}$, Rafel Simó ${ }^{1}$, Marta Estrada ${ }^{1}$ \\ ${ }^{1}$ Biologia Marina i Oceanografia, Institut de Ciències del Mar, Consejo Superior de Investigaciones Científicas, Barcelona, \\ Catalonia, Spain. \\ (SN) (Corresponding author) E-mail: sdena@icm.csic.es. ORCID iD: https://orcid.org/0000-0002-8272-4883 \\ (MZ) E-mail: zamanillo@icm.csic.es. ORCID iD: https://orcid.org/0000-0002-0753-4748 \\ (MD) E-mail: mdelgadom9@ hotmail.com. ORCID iD: https://orcid.org/0000-0001-8389-0472 \\ (CM) E-mail: celia@icm.csic.es. ORCID iD: https://orcid.org/0000-0002-5097-4829 \\ (RS) E-mail: rsimo@icm.csic.es. ORCID iD: https://orcid.org/0000-0003-3276-7663 \\ (ME) E-mail: marta@icm.csic.es. ORCID iD: https://orcid.org/0000-0001-5769-9498 \\ ${ }^{2}$ INIBIOMA, CONICET-UNComahue, San Carlos de Bariloche, Argentina. \\ (GLP) E-mail: perezgonzaloluis@ gmail.com. ORCID iD: https://orcid.org/0000-0001-8325-7677 \\ ${ }^{3}$ Instituto Español de Oceanografía (IEO), Spain. \\ (ML) E-mail: mikel.latasa@ieo.es. ORCID iD: https://orcid.org/0000-0002-8202-0923 \\ ${ }^{4}$ CNRS, Sorbonne Université, UMR 7621, Laboratoire d'Océanographie Microbienne, Banyuls-sur-Mer, France. \\ (EO-R) E-mail: ortegaretuerta@ obs-banyuls.fr. ORCID iD: https://orcid.org/0000-0003-0780-8347
}

\begin{abstract}
Summary: The relationships between the structure of the phytoplankton community and the bio-optical properties of surface waters were studied during the TransPEGASO cruise along a transect across the Atlantic Ocean that covered seven biogeographical provinces, from the Alborán Sea (SW Mediterranean) to the Patagonian Shelf. We characterized the composition of the phytoplankton community by means of high-performance liquid chromatography and CHEMTAX pigment analyses applied to whole water and two filtration size classes $(<3$ and $\geq 3 \mu \mathrm{m})$, flow cytometric determinations and microscopic observations. Additionally, the study was complemented by measurements of the absorption of particulate matter and coloured dissolved organic matter (CDOM). The size class distribution of the chlorophyll $a(\mathrm{Chl} a)$ obtained from the size-fractionated filtration (SFF) was compared with that resulting from the diagnostic pigment algorithms (VU) developed by Vidussi et al. (2001) and Uitz et al. (2006), and the total Chl $a$-based expressions (HI) of Hirata et al. (2011). The seven provinces crossed by the transect could be divided into an oligotrophic group with Chl $a<0.25 \mathrm{mg} \mathrm{m}^{-3}$ comprising the tropical and subtropical Atlantic (including the Canary Current Coastal Province), and a eutrophic group $\left(\right.$ Chl $a>0.5 \mathrm{mg} \mathrm{m}^{-3}$ ) with a single Mediterranean (MEDI) sample and those from the southwestern Atlantic Shelf (SWAS). According to CHEMTAX, the most important taxa in the tropical and subtropical Atlantic were Prochlorococcus, haptophytes and Synechoccoccus, while the MEDI and SWAS were dominated by diatoms and haptophytes. Both the VU and $\mathrm{HI}$ algorithms, which are based on pigment composition or Chl $a$ concentration, predicted for SWAS a high proportion of nano- and microphytoplankton, while the SFF indicated dominance of the $<3 \mu \mathrm{m}$ size class. In addition, the CHEMTAX results indicated a high average diatom contribution in this province. However, at several SWAS stations with relatively high values of diatom Chl $a$ estimated by CHEMTAX, the microscopic observations found only small concentrations of nano- or microplankton-sized cells. This discrepancy appeared to be due to the presence, confirmed by scanning electron microscopy, of picoplankton-sized cells of the diatom Minidiscus sp. and of Parmales (a group sharing the pigment composition with the diatoms). These findings caution against a routine assignment of diatom pigments to the microplankton size class. The total non-water absorption in the water column was dominated by CDOM. The average contribution of phytoplankton absorption for the different provinces ranged from $19.3 \%$ in the MEDI to $45.7 \%$ in the SWAS and $47 \%$ in the western tropical Atlantic (WTRA). The Chl $a$-specific phytoplankton absorption $\left[\mathrm{a}_{\mathrm{ph}} *(443), \mathrm{m}^{2} \mathrm{mg}^{-1}\right]$ was lower in the MEDI and SWAS than in the oligotrophic provinces. $\mathrm{a}_{\mathrm{ph}} *(443)$ was negatively correlated with the first principal component derived from a principal component analysis based on the concentration of the main pigments and was not correlated with indicators of phytoplankton community size structure such as the proportion of Chl $a$ in the $<3$ um class or a size index derived from the VU size class distribution. These findings indicate that the variability observed in $\mathrm{a}_{\mathrm{ph}} *(443)$ was mainly related to differences in pigment composition and possibly to photoacclimation processes, and that any package effects due to cell size were probably masked by other factors, an outcome that may be related to the relatively small influence of size within the narrow range of Chl $a$ concentrations (all $\leq 2.4 \mathrm{mg} \mathrm{m}^{-3}$ ) considered in our study.
\end{abstract}

Keywords: chemotaxonomy; CHEMTAX; size fractionation; bio-optics; Atlantic Ocean; CDOM. 
Clases de tamaño, grupos quimiotaxonómicos y propiedades bio-ópticas del fitoplancton a lo largo de un transecto desde el mar Mediterráneo al SO del océano Atlántico

Resumen: Durante la campaña TransPEGASO, realizada a lo largo de un transecto a través del Océano Atlántico que cubrió siete provincias biogeográficas, desde el mar de Alborán (Mediterráneo SO) hasta la Plataforma Patagónica, se estudiaron las relaciones entre la estructura de la comunidad fitoplanctónica y las propiedades bio-ópticas del agua. La composición del fitoplancton en muestras de agua entera y de dos fracciones de tamaño $(<3$ y $\geq 3 \mu \mathrm{m})$ obtenidas por filtración se caracterizó por medio de análisis de pigmentos por HPLC (de high-performance liquid chromatographyy), seguido de la aplicación del algoritmo CHEMTAX. Además, se llevaron a cabo determinaciones de citometría de flujo y observaciones microscópicas, y el estudio se complementó con mediciones de absorción de material particulado y materia orgánica disuelta coloreada (CDOM, de coloured dissolved organic matter). La distribución de la clorofila $a(\mathrm{Chl} a)$ entre las diversas clases de tamaño obtenidas mediante filtración fraccionada (SFF, de size-fractionated filtration) se comparó con las distribuciones derivadas de los algoritmos desarrollados por Vidussi et al. (2001) y Uitz et al. (2006) (VU), y por Hirata et al. (2011) (HI). Las siete provincias atravesadas por el transecto podían clasificarse en un grupo oligotrófico, con Chl $a<0.25 \mathrm{mg} \mathrm{m}^{-3}$, que comprende el Atlántico tropical y subtropical (incluida la provincia costera de Canarias) y un grupo eutrófico (Chl a $>0.5 \mathrm{mg} \mathrm{m}^{-3}$ ) con una sola muestra mediterránea (MEDI) y las de la plataforma patagónica, en el sudoeste del Atlántico (SWAS). Según CHEMTAX, los taxones más importantes en el Atlántico tropical y subtropical fueron Prochlorococcus, haptofitos y Synechoccoccus, mientras que las provincias MEDI y SWAS estuvieron dominadas por diatomeas y haptofitos. Tanto los algoritmos VU como los HI, que se basan en la composición de pigmentos o en la concentración de $\mathrm{Chl} a$, predijeron para SWAS una alta proporción de nano y microfitoplancton, mientras que la SFF indicó un dominio de la clase de tamaño $<3 \mu \mathrm{m}$. Por otra parte, los resultados de CHEMTAX indicaron que, en promedio, la contribución de las diatomeas era importante en esta provincia. Sin embargo, en varias estaciones de SWAS para las que CHEMTAX estimaba una elevada contribución de diatomeas, las observaciones microscópicas encontraron solamente escasas concentraciones de células de diatomeas de tamaño nano- o microplanctónico. Esta discrepancia parece deberse a la presencia, confirmada por microscopía electrónica de barrido, de pequeñas células $(<3 \mu \mathrm{m})$ de la diatomea Minidiscus sp. y de Parmales (un grupo que comparte la composición pigmentaria con las diatomeas). Estos hallazgos advierten contra una asignación rutinaria de los pigmentos de las diatomeas a la clase de tamaño de microplancton. La absorción total (sin contar la propia del agua) en la columna de agua estuvo dominada por CDOM. En promedio, la contribución de la absorción de fitoplancton para las diferentes provincias osciló de $19.3 \%$ en MEDI a $45.7 \%$ en SWAS y $47 \%$ en la provincia del Atlántico Tropical Occidental (WTRA). La absorción del fitoplancton por unidad de Chl $a$ [aph*(443), $\mathrm{m}^{2} \mathrm{mg}^{-1}$ ] fue menor en MEDI y SWAS que en las provincias oligotróficas. aph*(443) se correlacionó negativamente con el primer componente derivado de un análisis de los componentes principales basado en la concentración de los pigmentos más importantes y no se correlacionó con indicadores de la estructura de tamaños de la comunidad fitoplanctónica tales como la proporción de Chl $a$ en la clase $<3 \mu \mathrm{m}$ o un índice de tamaño (SI) derivado de la distribución de clases de tamaño obtenida mediante el algoritmo VU. Estas observaciones indican que la variabilidad observada en aph*(443) se relacionaba principalmente con diferencias en la composición pigmentaria y posiblemente también con procesos de fotoaclimatación del fitoplancton, y que cualquier efecto de empaquetamiento debido al tamaño de las células quedaba probablemente enmascarado por otros factores. Este último resultado puede estar relacionado con una influencia relativamente pequeña del tamaño dentro del estrecho rango de concentraciones de Chl $a$ considerado en nuestro estudio (todas eran $\leq 2.4 \mathrm{mg} \mathrm{m}^{-3}$ ).

Palabras clave: quimiotaxonomía; CHEMTAX; fraccionamiento por tamaños; bio-óptica; océano Atlántico; materia orgánica disuelta coloreada.

Citation/Como citar este artículo: Nunes S., Perez G.L., Latasa M., Zamanillo M., Delgado M., Ortega-Retuerta E., Marrasé C., Simó R., Estrada M. 2019. Size fractionation, chemotaxonomic groups and bio-optical properties of phytoplankton along a transect from the Mediterranean Sea to the Atlantic Ocean. Sci. Mar. 83(2): 87-109. https://doi.org/10.3989/ scimar.04866.10A

Editor: D. Vaqué.

Received: July 25, 2018. Accepted: September 25, 2018. Published: May 27, 2019.

Copyright: (c) 2019 CSIC. This is an open-access article distributed under the terms of the Creative Commons Attribution 4.0 International (CC BY 4.0) License.

\section{INTRODUCTION}

The microscopic photosynthetic protists and cyanobacteria of the phytoplankton, which inhabit the illuminated layers of water bodies, represent the main primary producers in the marine ecosystem, are a crucial agent in biogeochemical cycles and influence processes linking the atmosphere and the ocean. They are the main protagonists of the biological uptake of atmospheric $\mathrm{CO}_{2}$ in the ocean and play an important role in aerosol generation through the production of dimethyl-sulfoproprionate (DMSP), a precursor of dimethyl sulfide (DMS), and other volatile compounds (Simó 2001).

Phytoplankton comprise an enormous variety of taxa. By the end of the 1980s, descriptions based on morphology included around 4000 species (reviewed by Sournia et al. 1991), but current molecular techniques are uncovering a large amount of novel genetic diversity (de Vargas et al. 2015, Farrant et al. 2016). A way to manage this diversity, in particular regarding the biogeochemi- cal and trophic flow roles played by different groups, has been the recognition of life-forms or phytoplankton functional types, which consist of groupings of organisms based on some common traits of interest (Margalef 1978, Litchman and Klausmeier 2008). Phytoplankton functional types may be defined by properties such as the possession of flagella and the ability to migrate in the water column (as in the dinoflagellates), by their size, which is itself an important trait influencing other phytoplankton properties (Kiørboe 1993), or by the roles they play in biogeochemical cycles, such as silicification (diatoms), calcification (such as coccolithophores) and nitrogen fixation (certain cyanobacteria) (Le Queré et al. 2005, Zeng et al. 2018). Sometimes, the delimitation of functional types is based on the assumption that genetic relationships among taxa are associated with similar ecophysiological characteristics. Microscopic observations are a useful tool for classifying phytoplankton, but they are time-consuming and require a high level of expertise. High-performance liquid chromatography 
(HPLC) of phytoplankton pigments and the application of algorithms such as CHEMTAX (Mackey et al. 1996), based on diagnostic pigment markers, provide a reliable and efficient way to identify major chemotaxonomic phytoplankton groups.

Phytoplankton are traditionally divided into three size categories: micro- $(20-200 \mu \mathrm{m})$, nano- $(2-20 \mu \mathrm{m})$ and picophytoplankton $(0.2-2 \mu \mathrm{m})$. Phytoplankton size, in combination with other traits such as the presence of mineral walls, determines sinking rates and is a key factor influencing energy transfer through the food web and the potential export of carbon to the sediment (Kiørboe 1993, Klaas and Archer 2002). Thus, knowing the particle size distribution in a community is crucial for estimating vertical carbon fluxes and thereafter the efficiency of the biological carbon pump (Falkowski et al. 2003). In addition, as the particulate absorption and optical properties of a water body are strongly associated with the pigment composition and the size structure of the phytoplankton assemblages, the study of these community traits has relevant applications in the development of algorithms for the detection of chlorophyll, the modelling of primary production and the identification of phytoplankton functional types by remote sensing (Nair et al. 2008). This kind of information, which is fundamental for understanding the significance of phytoplankton community structure in global ocean biogeochemistry, requires in situ observations across large spatial scales covering regions with diverse characteristics (Gibb et al. 2000).

The TransPEGASO cruise, carried out during the southern spring of 2014, covered several biogeochemical provinces (Longhurst 2007) across the Atlantic Ocean and provided an opportunity to study environmental parameters, optical properties and phytoplankton community structure in the surface waters. Previous surveys across the Atlantic Ocean have provided information on some of the relevant variables; for example, size-fractionated chlorophyll $a(\mathrm{Chl} a)$ concentration (Marañón et al. 2001); phytoplankton pigment composition (Gibb et al. 2000, Aiken et al. 2009), pigment and absorption characteristics (Bouman et al. 2000, Barlow et al. 2002) and coloured dissolved organic matter (CDOM) (Kitidis et al. 2006). In this work, we strived to integrate environmental and biological measurements by means of a suite of complementary techniques, including size-fractionated filtration (SFF), microscopic and flow cytometric observations, and HPLC determination of chemotaxonomic pigment signatures, with two main objectives: 1) to obtain a robust characterization of the size and taxonomic structure of the phytoplankton communities; and 2) to ascertain the relationships between optical properties of the water (CDOM and particulate matter absorption) and the phytoplankton community structure.

\section{MATERIALS AND METHODS}

\section{The TransPEGASO cruise: sampling and physical measurements}

The TransPEGASO cruise was carried out on board the R/V Hespérides between 21 October and 21 No-

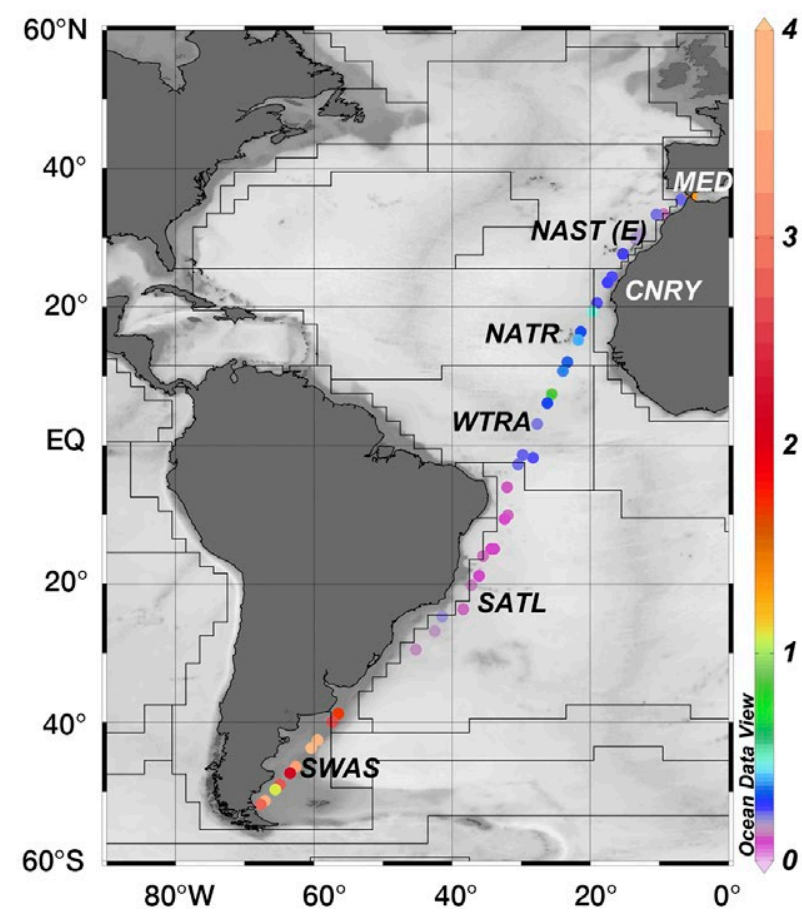

Fig. 1. - Position and biogeochemical provinces (Longhurst, 2007) of the sampling stations of the TransPEGASO cruise (21/10/201421/11/2014). The province names and abbreviations are: Mediterranean (MEDI), Atlantic Subtropical Gyre East (NAST- E), Canary Current Coastal (CNRY), North Atlantic Tropical Gyre (NATR), western tropical Atlantic (WTRA), South Atlantic Tropical Gyre (SATL) and Southwest Atlantic Continental Shelf (SWAS). The color scale indicates Fl_Chl $a$ in $\mathrm{mg} \mathrm{m}^{-3}$.

vember 2014. We sampled 42 oceanographic stations along a transect (Fig. 1) from the westernmost Mediterranean (Cartagena, Spain) and across the Atlantic Ocean to Punta Arenas (Chile), with a stopover in Buenos Aires between 8 and 16 November (Supplementary material Table S1). Based on geographic location and Chl $a$ concentration, we assigned the stations to seven biogeographical provinces (Longhurst 2007): Mediterranean (MEDI), North Atlantic Subtropical Gyre East (NAST- E), Canary Current Coastal (CNRY), North Atlantic Tropical Gyre (NATR), Western Tropical Atlantic (WTRA), South Atlantic Tropical Gyre (SATL) and Southwest Atlantic Continental Shelf (SWAS) (Table S1).

Water samples were obtained twice a day, at 9 a.m. and 4 p.m. local time (Table S1), through an underway flow-through system that collected water from 4 $m$ depth. The water was screened in situ (except for nutrients) through a $150-\mu \mathrm{m}$ nylon mesh to remove the larger particles, and the total sampling time did not exceed 90 seconds. Temperature, salinity and conductivity were determined with an online SBE 21 SeaCAT thermosalinograph.

\section{Nutrients, flow cytometry (FC) and fluorometric Chl $a$}

For determination of nitrate, nitrite, silicate and phosphate concentrations, $100 \mathrm{~mL}$ of seawater were introduced in Falcon vials that were kept frozen $\left(-20^{\circ} \mathrm{C}\right)$ until analysis in the home laboratory. The nutrient 
concentrations were measured colorimetrically with an Alliance Evolution II autoanalyser, following the procedures described in Hansen and Koroleff (1999).

Samples for flow cytometric analysis consisted of $4.5 \mathrm{~mL}$ of water that were preserved with $1 \%$ paraformaldehyde plus $0.05 \%$ glutaraldehyde (final concentrations), left to fix for 15 minutes, deep frozen in liquid nitrogen and stored at $-80^{\circ} \mathrm{C}$ until analysis (Zamanillo et al. 2019). The samples were analysed six months after the cruise, in the home laboratory, with a Becton Dickinson FACScalibur flow cytometer provided with a laser emitting at $488 \mathrm{~nm}$ (Gasol and Del Giorgio 2000). Before analysis, the samples were thawed and $10 \mu \mathrm{L}$ of a $10^{5} \mathrm{~mL}^{-1}$ solution of yellow-green $0.92 \mu \mathrm{m}$ Polysciences latex beads were added per $600 \mu \mathrm{L}$ sample as an internal standard. Synechococcus, Prochlorococcus, picoeukaryotes and flow cytometric nanoeukaryotes (hereafter FC-nanoeukaryotes) were identified on the basis of their autofluorescence and scattering properties.

For fluorometric Chl $a$ (Chl $\left.a \_F l\right)$ determinations, $250 \mathrm{~mL}$ of seawater were filtered through $25 \mathrm{~mm}$ Whatman GF/F glass fibre filters (nominal pore size $0.7 \mu \mathrm{m}$ ) using a $<200 \mathrm{~mm} \mathrm{Hg}$ vacuum. The filters were subsequently frozen at $-20^{\circ} \mathrm{C}$ and, after 24 hours, introduced into $90 \%$ acetone and kept in the dark at $4^{\circ} \mathrm{C}$ for another day. The $\mathrm{Chl} a \_\mathrm{Fl}$ concentrations were determined fluorometrically (Yentsch and Menzel 1963) using a calibrated Turner Designs fluorometer. No phaeopigment correction was carried out.

\section{Phytoplankton identification}

Approximately $250 \mathrm{~mL}$ of seawater sample was placed in glass bottles, preserved with formaldehyde solution (4\%) and stored in the dark until analysis on land. Phytoplankton examination was carried out by means of the inverted microscope method (Utermöhl 1958); $100 \mathrm{~mL}$ of water was introduced in composite chambers and left to settle for $48 \mathrm{~h}$. Subsequently, the entire base of the chambers was scanned at $125 \times$ to quantify the larger, less abundant organisms of the microphytoplankton $(>20 \mu \mathrm{m})$, and at least two transects were examined at $312 x$ to enumerate the smaller and more frequent nanophytoplankton forms $(<20 \mu \mathrm{m})$. When possible, phytoplankton was identified to the species level, but many organisms could not be adequately classified and were pooled in categories such as "Nanoflagellates 3-20 $\mu \mathrm{m}$ ", "Small dinoflagellates $(<20 \mu \mathrm{m})$ " or "Unidentified small coccolithophores $(<10 \mu \mathrm{m})$ ". Organisms in the picoplankton size range cannot be adequately quantified with this method.

\section{SFF and HPLC pigment determinations}

Pigment analysis by HPLC, following the method of Latasa (2014), was carried out for three phytoplankton size classes obtained on board by SFF (Herbland et al. 1985): total phytoplankton, nano- plus microphytoplankton, and picophytoplankton. For total phytoplankton (Chl $a$ _tot), we filtered the 0.35 - to 2-L water samples onto $25 \mathrm{~mm}$ Whatman GF/F glass fibre filters. For nano- plus microphytoplankton $\geq 3 \mu \mathrm{m}\left(\mathrm{Chl} a \_\mathrm{n}+\mathrm{m} \geq 3\right)$, we filtered 0.2 to $1.8 \mathrm{~L}$ of seawater at the SWAS province stations and $2.5 \mathrm{~L}$ in the other ones onto $25 \mathrm{~mm}$ Nuclepore polycarbonate filters ( $3 \mu \mathrm{m}$ pore size). The resulting filtrate was filtered again through $25 \mathrm{~mm}$ Whatman GF/F filters to collect the picophytoplakton $\left(\mathrm{Chl} a \_\right.$pico $\left.<3\right)$ class. Immediately after filtration, the filters were introduced into cryovials and stored frozen at $-80^{\circ} \mathrm{C}$ until analysis in the Xixón/Gijón laboratory of the Instituto Español de Oceanografía. The procedure for pigment extraction began by wetting the filters with $2.5 \mathrm{~mL}$ acetone $90 \%$ that contained an internal standard of trans- $\beta$-apo- 8 '-carotenal (Sigma), followed by sonication (30 seconds, $8 \times 10$ cycle and 40 intensity). After keeping the filters in acetone at $-20^{\circ} \mathrm{C}$ for $24 \mathrm{~h}$, the samples were vortexed, filtered again through Whatman $\mathrm{GF} / \mathrm{F}$ glass fibre filters to remove debris, and placed in amber cryovials. The extracts were analysed by HPLC using an Agilent series (Waldbronn, Germany) 1200 chromatographic system with a G1311A quaternary pump, a G1367C autosampler with a $100-\mu \mathrm{L}$ capillary loop, a G1316B column thermostat and a G1315C diode array detector. The sample volume injected was 1200 $\mu \mathrm{L}$ and the sequence of sample withdrawal and injection was $30 \mu \mathrm{L}$ sample-20 $\mu \mathrm{L}$ water-30 $\mu \mathrm{L}$ sample-20 $\mu \mathrm{L}$ water and ejection into seat, repeated 12 times; the composition of the eluents is detailed in Latasa (2014). A total of 36 pigments (Tables 1 and S2) were detected at 474 and $664 \mathrm{~nm}$ and identified by retention time with an online diode array detector. The peak area of the pigments was calculated with the Agilent ChemStation software. The Chl $a$ concentration in total (Chl $a$ _tot) and size-fractionated samples (Chl $a \_n+m \geq 3$ for the $\geq 3$ $\mu \mathrm{m}$ and $\mathrm{Chl} a \_$pico $<3$ for the $<3 \mu \mathrm{m}$ classes) was estimated as the sum of monovinyl chlorophyll $a$ (MV-Chl $a$ ), divinyl chlorophyll $a$ (DV-Chl $a$ ), chlorophyllide $a$ and chlorophyll $a$ allomers and epimers. DV-Chl $a$ did not reach detection level in the SWAS region. To facilitate comparison with other works, the relationship between Chl $a$ _tot and Chl $a \_$Fl is shown in Figure S1.

\section{Pigment-based estimation of phytoplankton size classes and physiological state}

An estimate of the size structure of the phytoplankton assemblages was obtained from pigment concentrations quantified by HPLC, by means of the diagnostic pigment algorithms (Table 2) of Vidussi et al. (2001), later refined by Uitz et al. (2006). In this approach, diatoms and dinoflagellates are considered as microphytoplankton, cryptophytes and flagellates containing 19'-Butanoyloxyfucoxanthin (19'But) and 19'-hexanoyloxyfucoxanthin (19'Hex) as nanophytoplankton, and cyanobacteria and "green flagellates" as picoplankton. An estimate of the total $\mathrm{Chl} a$ concentration can be obtained as a weighted sum of the seven diagnostic pigments considered (SDP, see Table 2). An additional evaluation of the three phytoplankton size fractions was obtained using the Chl $a$-based approach (Table 2) of Hirata et al. (2008, 2011).

A size index (SI) based on an expression derived by Bricaud et al. (2004) was used to synthesize the size structure of each algal assemblage: 
Size fractions and chemotaxonomic groups of phytoplankton across the Atlantic Ocean • 91

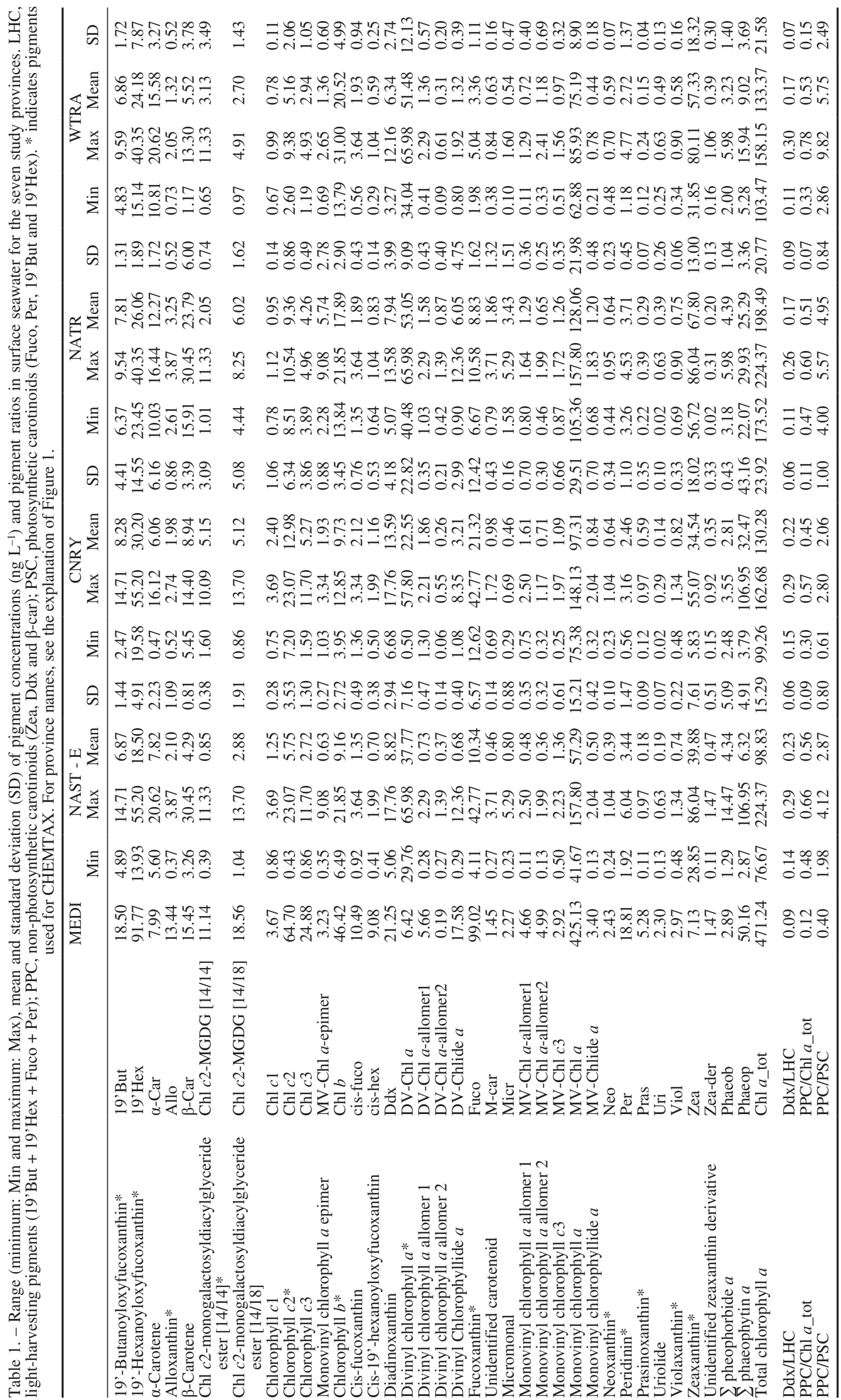

SCI. MAR. 83(2), June 2019, 87-109. ISSN-L 0214-8358 https://doi.org/10.3989/scimar.04866.10A 
Table 2. - Expressions for the estimation of the proportion of phytoplankton in the microplanktonic, nanoplanktonic and picoplanktonic size classes (f micro, f nano and f pico, respectively), based on diagnostic pigments [Vidussi et al. (2001) and Uitz et al. (2006)], and on the chlorophyll $a$ tot concentration (Hirata et al. 2011). $\Sigma$ DP is the total chlorophyll $a$ concentration recostructed from the concentrations of the considered diagnostic pigments.

\begin{tabular}{llc}
\hline Proportion & Vidussi et al. 2001/Uitz et al. 2006 & Hirata et al. 2011 \\
\hline f_micro & $1.41($ Fuco + Perid $) / \Sigma D P$ & {$[0.9117+\exp (-2.733 \mathrm{x}+0.4003)]^{-1}$} \\
f_nano & $\left(1.2719^{\prime} \mathrm{Hex}+0.3519^{\prime} \mathrm{But}+0.60\right.$ Allo $) / \Sigma \mathrm{DP}$ & $1-\mathrm{f}$ micro-f_pico \\
f_pico & {$\left[1.01 \mathrm{log} 10\left(\mathrm{Chl} a \_\right.\right.$tot $)+0.86$ Zea $/ \mathrm{SDP}$} & $-[0.1529+\exp (1.0306 \mathrm{x}-1.5576)]^{-1}-1.8597 \mathrm{x}+2.9954$ \\
$\Sigma \mathrm{DP}$ & $1.41 \mathrm{Fuco}+1.41 \mathrm{Per}+1.2719^{\prime} \mathrm{Hex}+0.6 \mathrm{Allo}+$ & \\
$\mathrm{x}$ & 0.3519 'But $+1.01 \mathrm{Chl} b+0.86 \mathrm{Zea}$ & \\
\hline
\end{tabular}

$$
\mathrm{SI}=\left(1 * \text { f_pico }+5 * f \_ \text {nano }+50 * \text { f_micro }\right)
$$

where $1 \mu \mathrm{m}, 5 \mu \mathrm{m}$ and $50 \mu \mathrm{m}$ are taken as representative sizes for the picophytoplankton (f_pico), nanophytoplankton (f_nano) and microphytoplankton (f_micro) proportions (expressed as a fraction of 1 ).

To assess the photoacclimation response to irradiance of the phytoplankton groups containing diadinoxanthin (Ddx) as the main light-protecting pigment, which include diatoms, dinoflagellates, haptophytes and pelagophytes, we calculated the ratio Ddx/LHC between the concentration of Ddx and the sum of the concentrations of four major light-harvesting carotenoids (LHC): fucoxanthin (Fuco), 19'But, 19'Hex and peridinin (Per).

\section{CHEMTAX processing}

Based on the main pigment markers, the contribution of different phytoplankton groups to total $\mathrm{Chl} a$ was calculated using version 1.95 of the CHEMTAX chemical taxonomy software (Mackey et al. 1996). Essentially, the CHEMTAX algorithm uses one or several initial matrices of pigment: Chl $a$ ratios for the selected phytoplankton groups to derive the contribution of each pigmentary class to the total $\mathrm{Chl} a$. The samples corresponding to Chl $a_{-}$tot, $\mathrm{Chl}$ $a \_\mathrm{n}+\mathrm{m} \geq 3$ and $\mathrm{Chl} a \_$pico $<3$ were clustered separately according to the contribution of the pigments 19'But, 19'Hex, alloxanthin (Allo), chlorophyll $b$ (Chl $b)$, chlorophyll $c 2$ (Chl $c 2)$, Chl $c 2$-monogalactosyldiacylglyceride ester [14/14] (Chl c2-MGDG [14/14]), divinyl chlorophyll $a$ (DV-Chl $a$, Fuco, neoxanthin (Neo), Per, prasinoxanthin (Pras), violaxanthin (Viol) and zeaxanthin (Zea); DV-Chl $a$ was removed in SWAS because it was below detection level. Each size class data set could be grouped into two clusters, one containing the SWAS samples (cluster 2) and one (cluster 1) containing the remaining ones (Table S2). CHEMTAX was run following the procedures of Latasa (2007) and Latasa et al. (2010). Briefly, we created 29 randomized copies of the initial ratio matrix and ran the program eight successive times. After the eighth run, a single average matrix was made and used again for a final run. Nine pigmentary groups were quantified for the whole and $<3 \mu \mathrm{m}$ size classes in MEDI, NAST-E, CNRY, NATR, WTRA and SATL provinces: chlorophytes, cryptophytes, diatoms, dinoflagellates, haptophytes, prasinophytes, pelagophytes, Prochlorococcus and Synechococcus. The same groups were considered for SWAS, except
Prochlorococcus, which was not found there. Both Prochlorococcus and Synechococcus were excluded from the calculations for the $\geq 3 \mu \mathrm{m}$ class.

\section{Optical measurements}

Water samples of 37 stations were collected and filtered through pre-combusted $\left(450^{\circ} \mathrm{C}, 4 \mathrm{~h}\right) 47-\mathrm{mm}$ Whatman GF/F glass fibre filters using an acid-cleaned all-glass filtration system and under positive pressure with low $\mathrm{N}_{2}$ flow. Immediately after filtration, CDOM absorbance was measured in the spectral range between 240 and $750 \mathrm{~nm}$ at 1-nm intervals in a Lambda 800 (Perkin-Elmer) dual-beam spectrophotometer equipped with a $10-\mathrm{cm}$ quartz cell, with pre-filtered $(0.2 \mu \mathrm{m})$ Milli-Q water used as a reference blank. The CDOM absorption coefficients at 254, 325 and $443 \mathrm{~nm}$ were calculated as follows:

$$
\mathrm{a}_{\mathrm{CDOM}}(\lambda)=2.303 * \mathrm{a}_{\text {filtrate }}(\lambda) / \mathrm{l}
$$

where $a_{\text {filtrate }}(\lambda)$ is the absorbance of the filtrate, $t$ is the path length (in $\mathrm{m}$ ) and 2.303 converts between $\log 10$ and natural $\log$.

Temperature and salinity effects were corrected by subtracting a null point (mean value between 700 to $750 \mathrm{~nm}$ ) from the entire scan (Mitchell et al. 2000). The wavelengths chosen for the study were $443 \mathrm{~nm}$ because of its use in remote sensing, and 325 and $254 \mathrm{~nm}$ because of their applicability to estimating dissolved organic carbon (DOC) concentrations (Weishaar et al. 2003, Baker and Spencer 2004).

For onboard determination of total particulate matter absorption coefficients [ $\mathrm{a}_{\mathrm{p}}(\lambda)$, with $\mathrm{m}^{-1}$ as units], seawater samples of 0.85 to $2 \mathrm{~L}$ were filtered through 25-mm-diameter GF/F filters. Immediately after filtration, absorbance was measured from 300 to $750 \mathrm{~nm}$ at $1-n m$ intervals in a Lambda 800 (Perkin-Elmer) dual beam spectrophotometer. Absorbance was checked to remain lower than 0.4 (Cleveland and Weidemann 1993). The $a_{p}(\lambda)$ were determined by the quantitative filter technique using the simple transmittance method of Mitchell et al. (2000). The blank scans obtained from filters wetted with filtered $(0.2 \mu \mathrm{m})$ seawater were subtracted. Absorption coefficients of non-algal particles $\left[\mathrm{a}_{\text {nap }}(\lambda)\right]$ (i.e. non-chlorophyllous, unpigmented particles) were determined using the methanol extraction method of Kishino et al. (1985). Absorption coefficients of $a_{p}(\lambda)$ (first measurement) and $a_{\text {nap }}(\lambda)$ (measurement after methanol extraction) were estimated according to the equation 


$$
\mathrm{a}_{\mathrm{p},} \mathrm{a}_{\text {nap }}(\lambda)=2.303 * \mathrm{a}_{\mathrm{filter}}(\lambda) * \mathrm{~S} / \mathrm{V} \beta(\lambda)
$$

where $a_{\text {filter }}(\lambda)$ is the measured absorbance with the quantitative filter technique, $S$ is the clearance area of the filter, $\mathrm{V}$ is the volume of filtered water, and $\beta(\lambda)$ is the amplification factor vector (Mitchell and Kiefer 1988). The $\beta(\lambda)$ factor was calculated following Bricaud and Stramski (1990) with the equation

$$
\beta(\lambda)=1.63 * \mathrm{a}_{\text {filter }}(\lambda)^{-0.22}
$$

In order to correct for residual offsets in the sample filter relative to the reference and for scattering artefacts due to particle loading (Mitchell et al. 2000), the optical density of all spectra was corrected by subtracting the readings at $750 \mathrm{~nm}$, a wavelength where absorbance by particles was assumed to be negligible.

Phytoplankton absorption coefficients $\left[\mathrm{a}_{\mathrm{ph}}(\lambda)\right]$ were obtained by subtracting $\mathrm{a}_{\text {nap }}(\lambda)$ from $\mathrm{a}_{\mathrm{p}}(\lambda)$. The Chl $a-$ specific phytoplankton absorption coefficient $\left[\mathrm{a}_{\mathrm{ph}} *(\lambda)\right]$ was estimated as $\mathrm{a}_{\mathrm{ph}}(\lambda) / \mathrm{Chl} a$ _tot. Finally, total absorption coefficients $\left[a_{t}(\lambda)\right.$ ] were calculated based on the equation

$$
\mathrm{a}_{\mathrm{t}}(\lambda)=\mathrm{a}_{\mathrm{CDOM}}(\lambda)+\mathrm{a}_{\mathrm{p}}(\lambda)+\mathrm{a}_{\mathrm{w}}(\lambda)
$$

where $a_{w}(\lambda)$, the absorption coefficient of pure water, was taken from Pope and Fry (1997) and from Morel et al. (2007) for the UV-blue range.

In general, $\mathrm{a}_{\mathrm{ph}} *(\lambda)$ depends not only on the pigmentary composition of the cells, but also on the so-called package effect, which consists of a reduction in the absorption of pigmented particles relative to the absorption of the pigments in solution. The package effect is stronger when either cell size or intracellular pigment concentration increase, and can be estimated by means of the package index $\mathrm{Qa}^{*}(443)$. This index can be calculated as the ratio of the phytoplankton absorption $\mathrm{a}_{\mathrm{ph}}(\lambda)$ and the absorption of pigments in solution $\mathrm{a}_{\text {sol }}(\lambda)$, following the approach of Bricaud et al. (2004), based on the weight-specific absorption coefficients proposed by Goericke and Repeta (1993) and the work by Bidigare et al. (1990):

$$
\begin{gathered}
\mathrm{a}_{\mathrm{pig}}(\lambda)=\mathrm{S} C_{\mathrm{i}} \mathrm{a}^{*}{ }_{\text {sol, } \mathrm{i}}(\lambda) \\
\mathrm{a}_{\mathrm{sol}}(\lambda)=\mathrm{a}_{\mathrm{pig}}(\lambda)+\mathrm{a}_{\text {miss }}(\lambda)
\end{gathered}
$$

where $\mathrm{a}_{\text {pig }}(\lambda)$ is the sum of pigment-specific absorption coefficient of the $i$-th pigment $\left[\mathrm{a}^{*}\right.$ sol, $\left.\mathrm{i}(\lambda)\right]$ multiplied by their concentrations $\left(C_{\mathrm{i}}, \mathrm{mg} \mathrm{m}^{-3}\right)$ in the medium, The $a_{\text {miss }}(\lambda)$ expression is a so-called "missing term" that depends on total $\mathrm{Chl} a$ (Chl $a$ _tot) concentration $\left[\mathrm{a}_{\text {miss }}(\lambda)=0.0525^{*} \mathrm{Chl} a\right.$ tot $^{\wedge} 0.85$; Bricaud et al. 2004]. The $\mathrm{Qa}^{*}(\lambda)$ index can increase from 0 (maximum package effect) to 1 (no package effect).

In order to assess the effect of accessory pigment composition on phytoplankton absorption properties, we grouped the carotenoids into two categories: nonphotosynthetic carotenoids (PPC), including Zea, Ddx and $\beta$-carotene, and photosynthetic carotenoids (PSC), comprising Fuco, Per, 19'But and 19'Hex (Bricaud et al. 2004).

\section{Statistical analyses}

The Chl a concentrations derived from the Uitz et al. (2006) and Hirata et al. (2011) estimates (hereafter referred to as $\mathrm{VU}$ and $\mathrm{HI}$, respectively) for the different size categories were compared with the SFF results using the standardized major axis (sma) regression method (Falster et al. 2006), which is appropriate (Warton et al. 2006) for testing whether the slope fits a specific value ( 1 in this case).

In order to summarize the pigment composition of the samples, a principal component analysis (PCA) was performed on the correlation matrix among the concentrations of the 11 most abundant pigments plus the biomarkers Allo, Neo, Per, Pras and Viol (Légendre and Légendre 1998). The concentration data $\left(x_{\mathrm{i}}\right)$ were transformed according to the expression $y_{\mathrm{i}}=\log \left(x_{\mathrm{i}}+\right.$ 0.1 ), where 0.1 is the minimum non-zero concentration measured in the data set.

\section{RESULTS}

\section{Oceanographic characterization of the transect}

The TransPEGASO transect crossed seven biogeochemical provinces between MEDI and SWAS (Fig. 1), encountering a wide range of hydrographical properties (Fig. 2, Table 3). Temperature (Fig. 2A) was about $21^{\circ} \mathrm{C}$ in MEDI, increased to mean values (Table 3 ) of $28.7^{\circ} \mathrm{C}$ and $28.2^{\circ} \mathrm{C}$ in NATR and WTRA, respectively, and decreased to $8-14^{\circ} \mathrm{C}$ in SWAS. Salinity (Fig. 2A, Table 3) ranged from 34.8 to 36.8 between MEDI and CNRY, showed a minimum of 34.8 in WTRA, increased again in SATL (36.3-37.4) and decreased to 32.6-33.6 in SWAS.

Nitrate, nitrite, and phosphate concentrations (Fig. 2B, C, Table 3) were generally low from MEDI to NATL and relatively high in SWAS, where the mean concentrations of these nutrients were respectively 4.08 $\mu \mathrm{M}, 0.13 \mu \mathrm{M}$ and $0.57 \mu \mathrm{M}$. Silicate (Fig. 2C) concentration was low $(0.2-1.42 \mu \mathrm{M})$ and very variable across the whole transect. The $\mathrm{N}: \mathrm{P}$ ratio [(nitrate+nitrite)/ phosphate] was always lower than the Redfield value of 16 (Table 3 ).

\section{Chl $a$ and HPLC pigments}

Hereafter, unless otherwise stated, for simplicity Chl $a$ concentrations will refer to the HPLC determinations. Chl $a_{-}$tot and the sum of the HPLC-measured Chl $a \_$pico $<3$ and $\mathrm{Chl} a \_\mathrm{n}+\mathrm{m} \geq 3$ classes $\left(\mathrm{Chl} a \_\mathrm{pico}+\mathrm{n}+\mathrm{m}\right)$ were correlated (Fig. S1B) (Chl $a \_$pico $+\mathrm{n}+\mathrm{m}=0.85+$ Chl $a$ _tot $+0.005 ; \mathrm{n}=41, \mathrm{r}^{2}=0.95, \mathrm{p}<0.0001$; one outlier was excluded) but the slope was $<1$ (the $95 \%$ confidence limits were 0.79-0.92).

The highest Chl a_tot concentrations (Fig. 2D, Table 1) were recorded in the shelf waters of SWAS $\left(\right.$ mean $\left.\pm S D, 1.40 \pm 0.54 \mathrm{mg} \mathrm{m}^{-3}\right)$, followed by those of MEDI ( $0.47 \mathrm{mg} \mathrm{m}^{-3} \mathrm{Chl} a \_$tot $)$. In the remaining regions, average $\mathrm{Chl} a$ _tot ranged from $0.06 \pm 0.02 \mathrm{mg}$ $\mathrm{m}^{-3}$ (SATL) to $0.20 \pm 0.02 \mathrm{mg} \mathrm{m}^{-3}$ (NATR). The Chl $a \_$pico $<3$ and $\mathrm{Chl} a \_\mathrm{n}+\mathrm{m} \geq 3$ classes followed a similar 

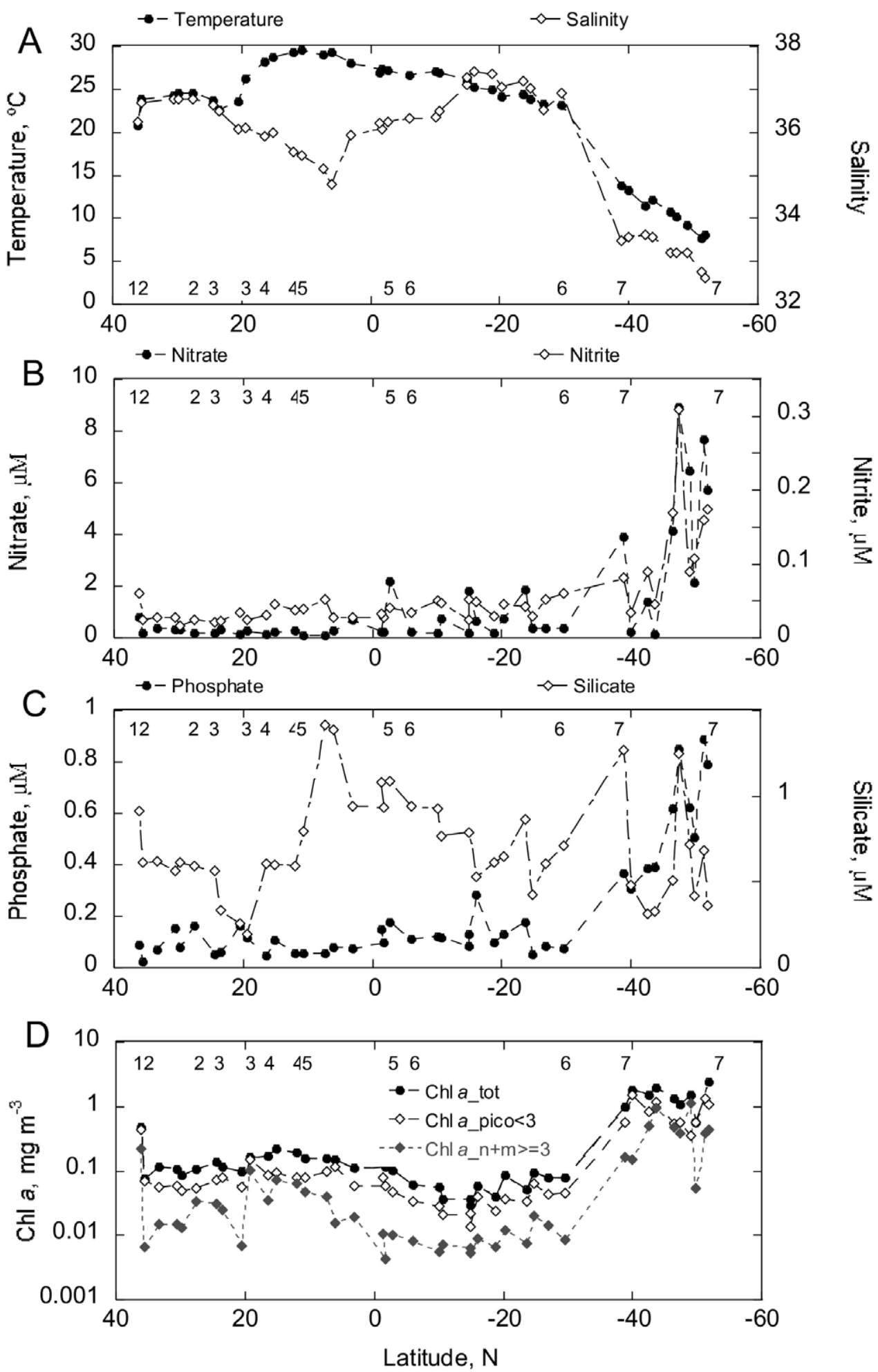

Fig. 2. - Variations of temperature $\left({ }^{\circ} \mathrm{C}\right)$ and salinity $(\mathrm{A})$, nitrate $(\mu \mathrm{M})$ and nitrite $(\mu \mathrm{M})(\mathrm{B})$, phosphate $(\mu \mathrm{M})$ and silicate $(\mu \mathrm{M})(\mathrm{C})$ and $\mathrm{Chl} a(\mathrm{mg}$ $\mathrm{m}^{-3}$ ) for the total community (Chl $a$ tot) and for the $<3 \mu(\mathrm{Chl} a$ pico $<3)$ and $\geq 3 \mu \mathrm{m}(\mathrm{Chl} a$ n+m $\geq 3)$ size classes (D), in the TransPEGASO transect. The numbers above the top or bottom axes indicate the provinces: 1, MEDI; 2, NAST-E; 3, CNRY; 4, NATR; 5, WTRA; 6, SATL; 7, SWAS.

pattern (Fig. 2D), with the highest values in SWAS and MEDI. No significant correlations were obtained when the proportion of $\mathrm{Chl} a$ in the picoplankton size fraction (f_pico<3) was compared with Chl $a$ _tot (Fig. $\mathrm{S} 1 \mathrm{C}$ ). The differences among average $\mathrm{f} \_$pico $<3$ (Fig.
3A) for the different provinces were not significant (Kruskal-Wallis test).

The main phytoplankton pigments determined by HPLC in each province (and the name abbreviations used hereafter) are presented in Table 1 for whole 
Table 3. - Range (minimum: Min and maximum: Max), mean and standard deviation (SD) of temperature (1 C), salinity, ratio between the sum of nitrite + nitrate and phosphate $(\mathrm{P} / \mathrm{N})$ and major nutrients (nitrate, nitrite, silicate and phosphate, $\mu \mathrm{M})$ for the seven study provinces. For province names, see the explanation in Figure 1.

\begin{tabular}{|c|c|c|c|c|c|c|c|c|c|c|c|c|c|}
\hline \multirow{2}{*}{ Variables } & \multirow{2}{*}{ MEDI } & \multicolumn{4}{|c|}{ NAST - E } & \multicolumn{4}{|c|}{ CNRY } & \multicolumn{4}{|c|}{ NATR } \\
\hline & & Min & Max & Mean & SD & Min & Max & Mean & SD & Min & Max & Mean & SD \\
\hline Temperature, $\left[{ }^{\circ} \mathrm{C}\right]$ & 20.75 & 23.83 & 24.62 & 24.31 & 0.35 & 22.63 & 26.21 & 24.05 & 1.53 & 28.13 & 29.59 & 28.72 & 0.57 \\
\hline Salinity & 36.25 & 36.70 & 36.77 & 36.75 & 0.04 & 36.07 & 36.65 & 36.33 & 0.29 & 35.56 & 35.99 & 35.82 & 0.24 \\
\hline $\mathrm{N} / \mathrm{P}$ & 9.5 & 1.23 & 9.09 & 4.56 & 3.11 & 1.00 & 6.07 & 3.56 & 2.23 & 2.62 & 5.65 & 3.90 & 1.57 \\
\hline Nitrate, $\mu \mathrm{M}$ & 0.78 & 0.18 & 0.40 & 0.28 & 0.10 & 0.13 & 0.35 & 0.24 & 0.09 & 0.14 & 0.27 & 0.22 & 0.07 \\
\hline Nitrite, $\mu \mathrm{M}$ & 0.06 & 0.02 & 0.05 & 0.02 & 0.01 & 0.02 & 0.04 & 0.03 & 0.01 & 0.03 & 0.05 & 0.04 & 0.01 \\
\hline Silicate, $\mu \mathrm{M}$ & 0.92 & 0.57 & 1.42 & 0.60 & 0.02 & 0.20 & 0.57 & 0.34 & 0.16 & 0.59 & 1.42 & 0.60 & 0.01 \\
\hline \multirow[t]{3}{*}{ Phosphate, $\mu \mathrm{M}$} & 0.09 & 0.02 & 0.16 & 0.10 & 0.06 & 0.05 & 0.16 & 0.10 & 0.05 & 0.05 & 0.11 & 0.07 & 0.03 \\
\hline & & \multicolumn{4}{|c|}{ WTRA } & \multicolumn{4}{|c|}{ SATL } & \multicolumn{4}{|c|}{ SWAS } \\
\hline & & Min & $\operatorname{Max}$ & Mean & SD & Min & $\operatorname{Max}$ & Mean & $\mathrm{SD}$ & Min & $\operatorname{Max}$ & Mean & SD \\
\hline Temperature, $\left[{ }^{\circ} \mathrm{C}\right]$ & & 26.89 & 29.59 & 28.20 & 1.12 & 23.21 & 27.08 & 25.16 & 1.38 & 7.63 & 13.88 & 10.74 & 2.18 \\
\hline Salinity & & 34.80 & 36.23 & 35.70 & 0.56 & 36.32 & 37.41 & 36.92 & 0.40 & 32.62 & 33.62 & 33.25 & 0.36 \\
\hline $\mathrm{N} / \mathrm{P}$ & & 1.86 & 12.56 & 5.07 & 4.22 & 1.89 & 14.50 & 5.81 & 3.91 & 0.53 & 10.87 & 6.53 & 3.92 \\
\hline Nitrate, $\mu \mathrm{M}$ & & 0.09 & 2.18 & 0.55 & 0.75 & 0.18 & 1.89 & 0.65 & 0.60 & 0.16 & 8.92 & 4.08 & 3.08 \\
\hline Nitrite, $\mu \mathrm{M}$ & & 0.03 & 0.05 & 0.04 & 0.01 & 0.03 & 0.06 & 0.04 & 0.01 & 0.04 & 0.31 & 0.13 & 0.08 \\
\hline Silicate, $\mu \mathrm{M}$ & & 0.79 & 1.42 & 1.09 & 0.23 & 0.43 & 0.94 & 0.72 & 0.16 & 0.32 & 1.27 & 0.63 & 0.36 \\
\hline Phosphate, $\mu \mathrm{M}$ & & 0.05 & 0.18 & 0.10 & 0.05 & 0.05 & 0.29 & 0.12 & 0.06 & 0.31 & 0.89 & 0.57 & 0.21 \\
\hline
\end{tabular}
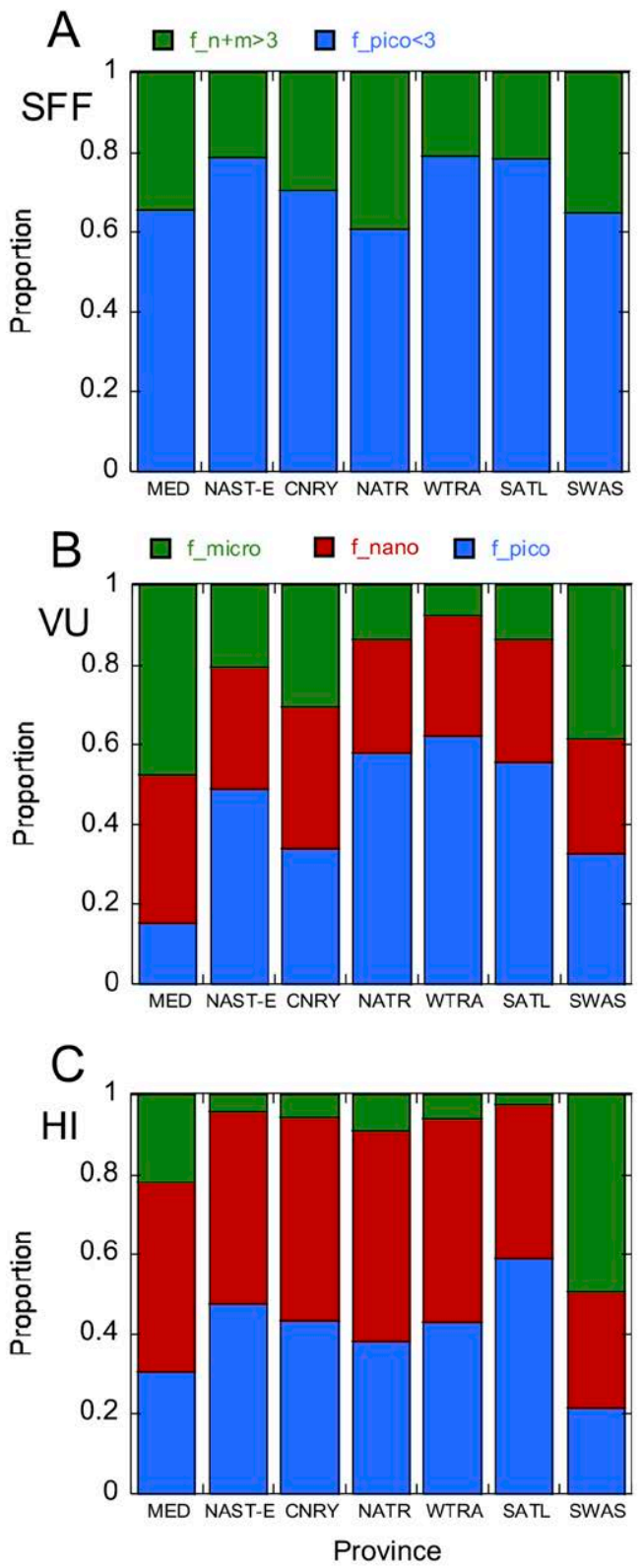

water and in Suplementary material Tables S3 and S4 for the Chl $a \_n+m \geq 3$ and $C h l a \_$pico $<3$ classes, respectively. Aside from MV-Chl $a$, the most important pigments present in the whole community (Fig. S2, Table 1) were Chl $b$, Fuco and 19'Hex in SWAS, and Fuco, 19'Hex and Chl $c 2$ in MEDI. CNRY was characterized by the dominance of Zea, Phaeop, 19'Hex and DV-Chl $a$ and the most important pigments in the other provinces were Zea, DV-Chl $a$ and 19'Hex. The most abundant pigments (excluding MV-Chl $a$ ) in Chl $a_{-} \mathrm{n}+\mathrm{m} \geq 3$ included Fuco (dominant in MEDI and SWAS), Phaeop and 19'Hex (Fig. S2, Table S3). In Chl $a \_$pico<3 (Fig. S2, Table S4), Zea and DV-Chl $a$ (in varying order of abundance) were the most important pigments (apart from MV-Chl $a$ ) in NAST-E, NATR, WTRA and SATL, followed by 19'Hex; Zea and Phaeop dominated in CNRY, Chl $b$ and 19'Hex in MEDI, and Fuco, 19' Hex and Chl $b$ in SWAS.

The PCA returned two principal components with $>1$ eigenvalues, which together explained $85.5 \%$ of the total variance of the 16 pigment descriptors (Table 4). The first principal component (PC1) had correlations exceeding 0.82 with all pigments except Zea and DVChl $a$, which were negatively correlated with it (Table 4). The second principal component (PC2) showed a strong positive correlation with Zea (0.96) and correlation coefficients $<0.3$ with all the other pigments (Table 4). The scores of PC1 (Fig. S1D) expressed the contrast between the high $\mathrm{Chl} a$ provinces (MEDI and SWAS) on the positive side and the other provinces in the negative one. PC2 appeared to be mainly related to the variability of Zea in the SWAS province, although

Fig. 3. - Size distribution of Chl $a$ determined by different approaches: A, proportion of nano+microphytoplankton ( $\mathrm{f} n+\mathrm{m} \geq 3$ ) and picophytoplankton (f_pico $<3$ ) derived from fractionated filtration; B, proportion of microphytoplankton (f_micro), nanophytoplankton (f_nano) and picophytoplankton (f_pico) estimated by the Vidussi et al. (2001)- Uitz et al. (2006) algorithm (VU); and $\mathrm{C}$ as in B, but estimated by the Hirata et al. (2011) algorithm (HI). The colour codes have been adjusted to facilitate comparison with Figure 7 (greenish for picoplankton, reddish for nanoplankton and bluish for microplankton). 
Table 4. - Correlation coefficients (loadings), ordered by magnitude, of the two first principal components on the 16 pigment descriptors.

\begin{tabular}{lcll}
\hline PC1 loadings & \multicolumn{3}{c}{ PC2 loadings } \\
\hline DV-Chl $a$ & -0.91 & Chl $c$ 2-MGDG [14/14] & -0.26 \\
Zea & -0.14 & Phaeop & -0.07 \\
Per & 0.82 & Fuco & -0.06 \\
Chl $c$ 2-MGDG [14/14] & 0.82 & Chl $c 2$ & -0.06 \\
Viol & 0.86 & $19^{\prime} H e x$ & -0.01 \\
Phaeop & 0.89 & Pras & -0.01 \\
19'Hex & 0.89 & Chl $c 3$ & 0.00 \\
Allo & 0.90 & Allo & 0.02 \\
Chl $b$ & 0.91 & Per & 0.05 \\
19'But & 0.91 & Ddx & 0.05 \\
Chl $c 2$ & 0.95 & 19'But & 0.10 \\
Fuco & 0.95 & Viol & 0.13 \\
Neox & 0.96 & Neox & 0.15 \\
Ddx & 0.97 & DV-Chl $a$ & 0.16 \\
Chl $c 3$ & 0.97 & Chl $b$ & 0.25 \\
Pras & 0.98 & Zea & 0.96 \\
\hline
\end{tabular}

it also singled out a CNRY sample with relatively low Zea concentration (Fig. S1D).

The ratio Ddx/LHC ranged from a low value of 0.09 in MEDI to a peak of 0.40 in SWAS and showed fluctuations that appeared to be linked to the morning-afternoon alternation of the sampling times (Fig. 4A); there was a weak but significant correlation $\left(n=40, r^{2}=0.14, p<0.05\right.$; Fig. S3A) between solar radiation and the $\mathrm{Ddx} / \mathrm{LHC}$ ratio. Both the $\mathrm{PPC} /$ Chl $a$ _tot (data not shown) and the PPC/PSC (Fig. 4B) pigment ratio peaked in the tropical and subtropical Atlantic and showed their lowest values in MEDI and SWAS.

\section{Phytoplankton composition}

All CHEMTAX groups except Synechococcus and Prochlorococcus showed generally low abundances in the tropical and subtropical Atlantic, and peaked in SWAS and to a smaller extent in MEDI (Figs 5-7, Table 5). Prochlorococcus showed maximum concentrations in WTRA and did not occur in SWAS (Fig. 5A), and Synechococcus peaked in NATR around $15.1^{\circ} \mathrm{N}$, and at several SWAS stations (Fig. 5B). Haptophytes represented a substantial part of the phytoplankton community in all provinces and diatoms and prasinophytes were important in MEDI and SWAS (Fig. 7A). Superimposed on these general patterns, there was noticeable heterogeneity within stations of the same province, in particular in SWAS, which showed a haptophyte Chl $a$ maximum at station $34\left(39.56^{\circ} \mathrm{S}\right)$ (Fig. 6D) and a diatom peak evidenced by both cell counts and $\mathrm{Chl} a$ concentrations at station $36\left(-43.43^{\circ} \mathrm{S}\right)$ (Fig. 6B).

In the $n+m \geq 3$ size class (Fig. $7 B$ ), the most important CHEMTAX groups were diatoms and haptophytes in MEDI, NAST-E, CNRY, NATR and SWAS; haptophytes, chlorophytes and dinoflagellates in WTRA; and haptophytes, dinoflagellates and prasinophytes in SATL. The pico $<3$ class (Fig. 7C) was dominated by prokaryotes in NAST-E, NATR, WTRA and SATL but also showed a high contribution of diatoms in CNRY, of diatoms and prasinophyes in MEDI and SWAS, and of haptophytes in all provinces.

There were significant correlations between the CHEMTAX-derived contribution to Chl $a$ _tot and
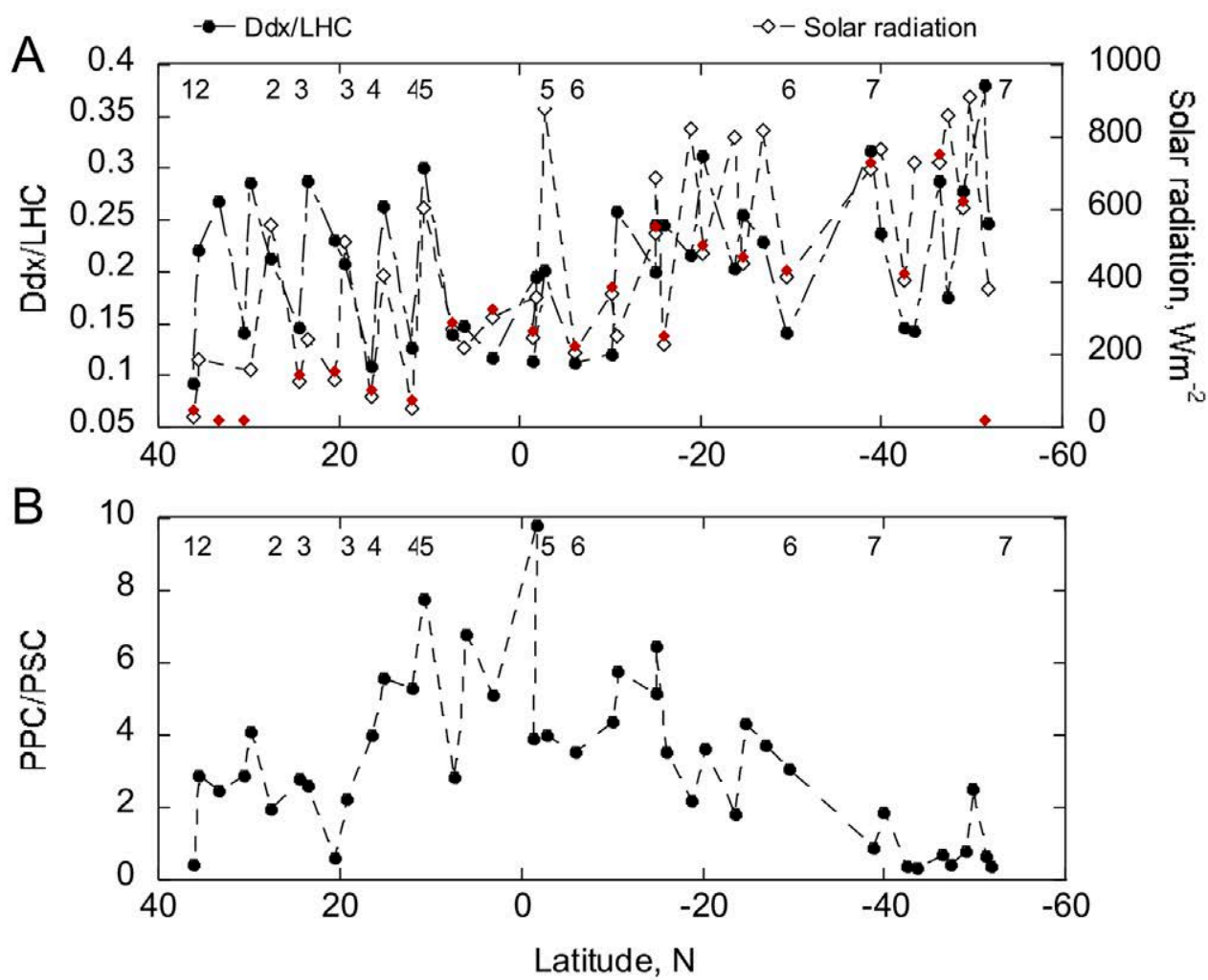

Fig. 4. - Latitudinal variation along the TransPEGASO transect of Ddx/LHC and solar radiation (W $\mathrm{m}^{-2}$ ) (A), and PPC/PSC (B). The red diamonds in A designate the morning stations and the numbers above the top or bottom axes indicate the provinces: 1, MEDI; 2, NAST-E; 3, CNRY; 4, NATR; 5, WTRA; 6, SATL; 7, SWAS. 


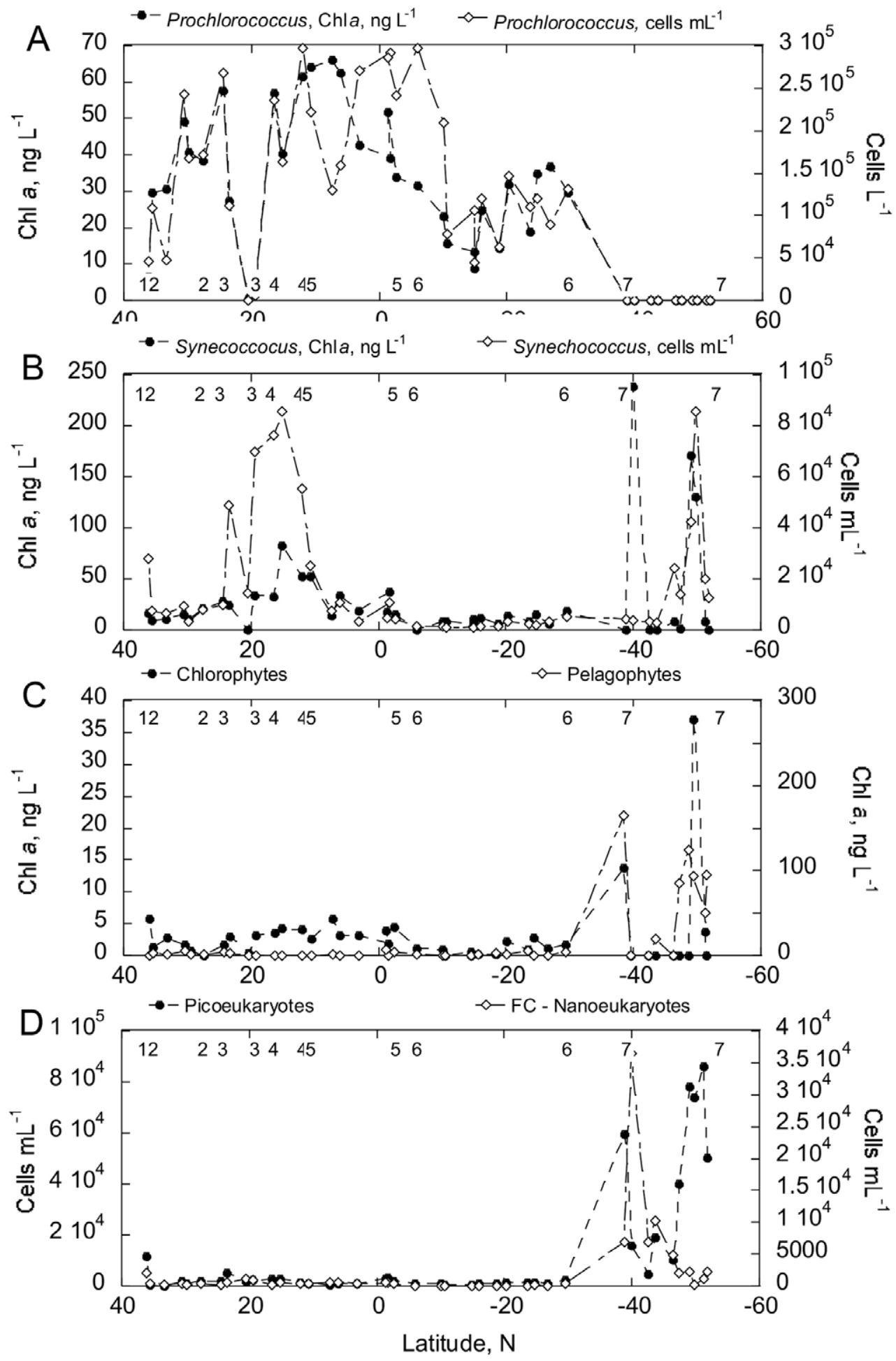

Fig. 5. - Latitudinal variation of CHEMTAX-derived $\mathrm{Chl} a\left(\mathrm{ng} \mathrm{L}^{-1}\right)$ and cell counts (cells $\mathrm{L}^{-1}$ ) for Prochlorococcus (A) and Synechococcus (B); C, latitudinal variation of CHEMTAX-derived Chl $a\left(\mathrm{ng} \mathrm{L}^{-1}\right)$ for chlorophytes (left ordinate scale) and pelagophytes (right ordinate scale); and flow cytometric counts (cells ml-1) of autotrophic picoeukaryotes (left ordinate scale) and nanoeukaryotes (right ordinate scale)

cell counts (microscopy for eukaryotes and flow cytometry for the prokaryotes and FC-nanoeukaryotes) of cryptophytes $\left(n=37, r^{2}=0.20, p<0.01\right)$, dinoflagellates $\left(\mathrm{n}=29, \mathrm{r}^{2}=0.24, \mathrm{p}<0.01\right)$, Prochlorococcus $(\mathrm{n}=31$, $\left.\mathrm{r}^{2}=0.70, \mathrm{p}<0.0001\right)$ and Synechococcus $\left(\mathrm{n}=41, \mathrm{r}^{2}=0.44\right.$, $\mathrm{p}<0.0001$, one outlier excluded). FC-nanoeukaryotes were also correlated with haptophyte Chl $a \quad(n=39$, $\left.\mathrm{r}^{2}=0.90, \mathrm{p}<0.0001\right)$. The global correlation was also significant for diatoms $\left(n=29, r^{2}=0.15, p<0.05\right)$, but there were marked discrepancies between the $\mathrm{Chl} a$ contribution and the cell counts for this group at some stations of CNRY and SWAS (Fig. 6B). 

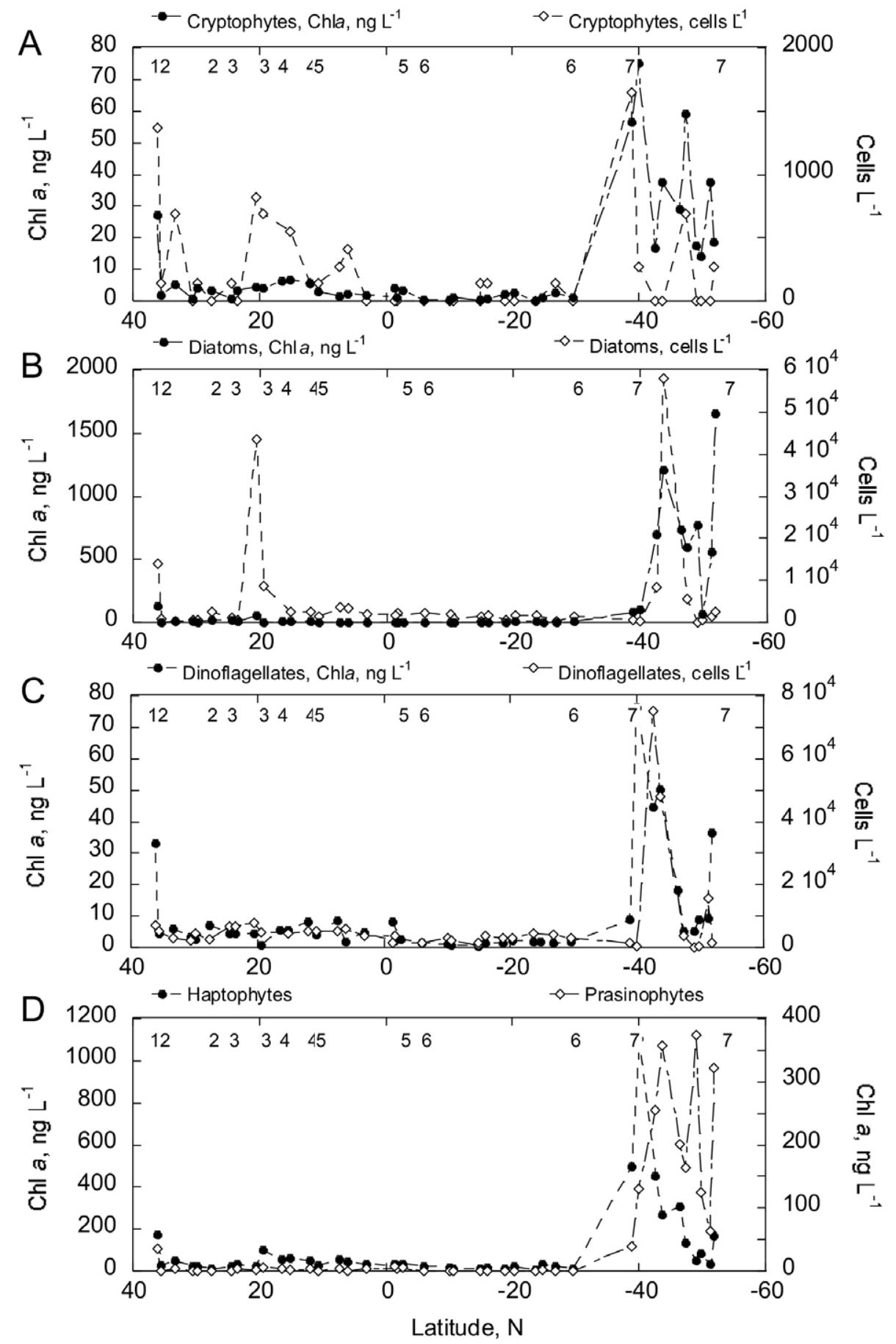

Fig. 6. - Latitudinal variation of CHEMTAX-derived Chl $a\left(n g \mathrm{~L}^{-1}\right)$ and cell counts (cells $\left.\mathrm{L}^{-1}\right)$ for cryptophytes (A), diatoms (B), dinoflagellates (C), and latitudinal variation of CHEMTAX-derived Chl $a\left(\mathrm{ng} \mathrm{L}^{-1}\right)$ for haptophytes (left ordinate scale) and prasinophytes (right ordinate scale) (D).

According to microscopy (Table S5), the most abundant diatom taxon in MEDI was Guinardia striata. The diatom peaks of stations 9 and $10\left(19^{\circ} 02^{\prime} \mathrm{W}\right.$, $20^{\circ} 33^{\prime} 02^{\prime \prime} \mathrm{N}$ and $19^{\circ} 39^{\prime} 26^{\prime \prime} \mathrm{W}, 19^{\circ} 19^{\prime} 54^{\prime \prime} \mathrm{N}$; respectively) of CNRY were mainly contributed by Chaetoceros spp. $<20 \mu \mathrm{m}$ and Pseudo-nitzschia spp. (thin). In the other provinces of the Subtropical and Tropical Atlantic, diatoms were represented by low densities of Cylindrotheca closterium, Hemiaulus hauckii, Thalas-
siosira/Porosira spp. $>20 \mu \mathrm{m}$, Proboscia alata and Pseudosolenia calcaravis. The most abundant diatom taxa in SWAS were Chaetoceros criophilus, C. lorenzianus, Chaetoceros $<20 \mu \mathrm{m}$, Thalassiosira $<20$ $\mu \mathrm{m}$ and Eucampia spp. The CHEMTAX algorithm indicated that, on average, diatoms were dominant in SWAS (Fig. 7), but for same stations of this zone (Fig. 6B) this abundance was not associated with high cell counts. Flow cytometric measurements revealed a 

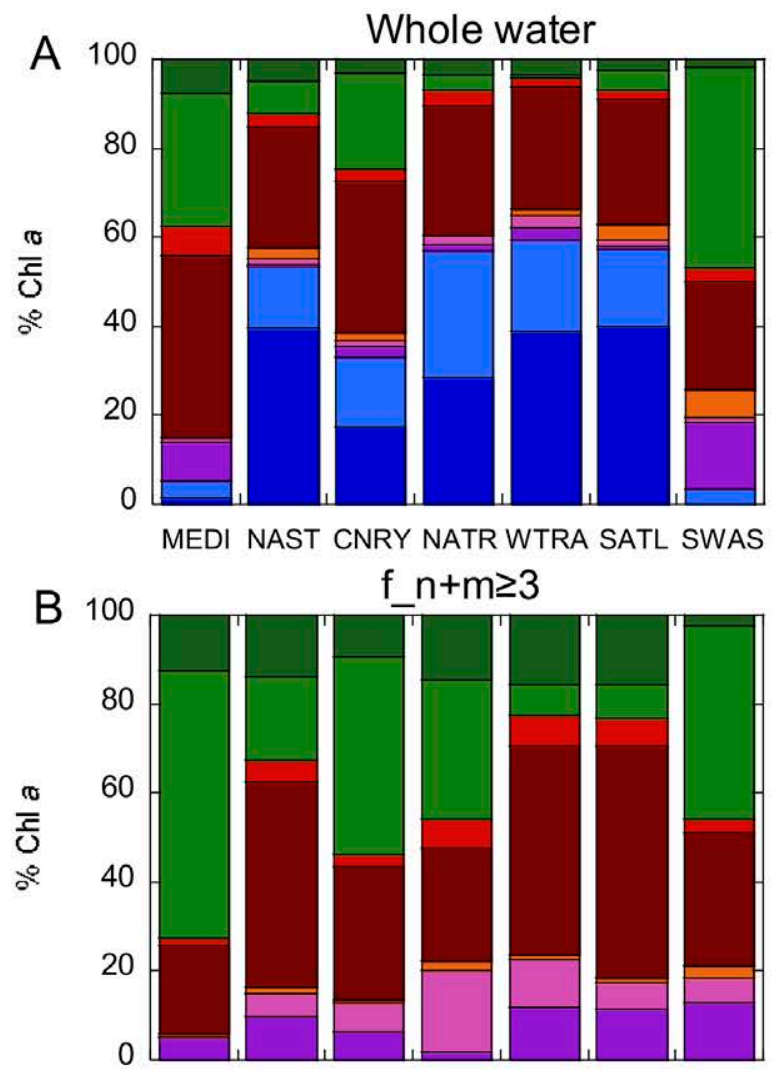

MEDI NAST CNRY NATR WTRA SATL SWAS

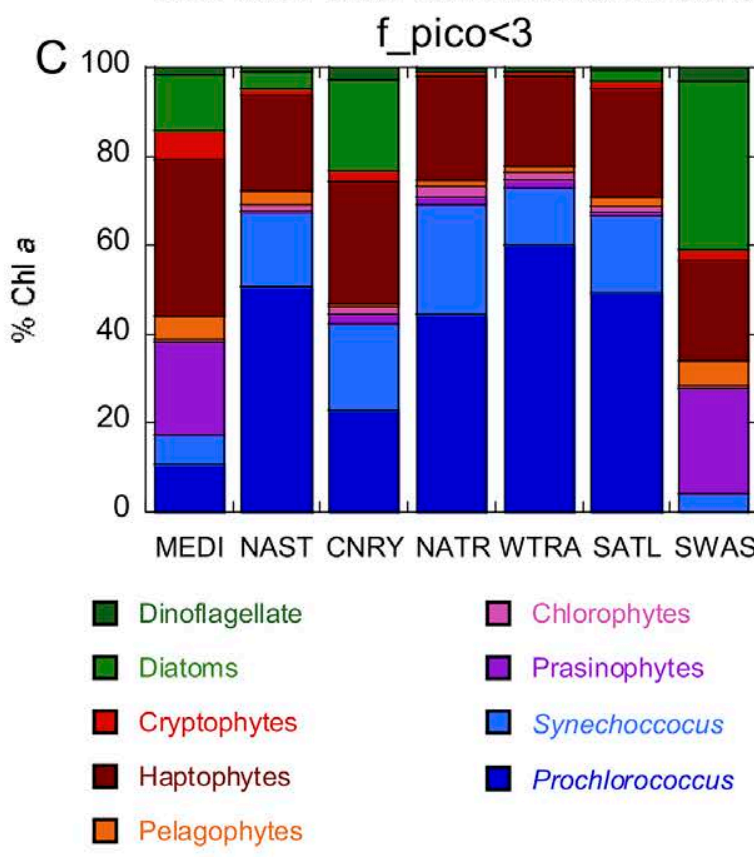

Fig. 7. - Percentage contribution of the chemotaxonomic phytoplankton groups to Chl $a$ _tot for the whole community (A), the nano+microphytoplankton (f_n+m $\geq 3$ ) size class $(B)$, and the picophytoplankton (f_pico<3) size class $(\mathrm{C})$.

substantial increase in pico- and FC-nanoeukaryotes at several stations of SWAS (Fig. 5D); a high presence of cells in the picoplankton size range could also be seen by optical microscopy in some SWAS samples (data not shown), but their concentration could not be properly quantified. SEM examination of water from these samples revealed the presence of the diatom Minidiscus sp. and of Triparma laevis, a member of the Parmales (Fig. S4), a phytoplankton group genetically very close to the diatoms, with which it shares a similar pigmentary suite (Ichinomiya et al. 2010). The Parmales have small cells with siliceous plates and are ubiquitous in marine waters (Ichinomiya and Kuwata 2015, Ichinomiya et al. 2016). Both Minidiscus and the Parmales (Kaczmarska et al. 2009, Jewson et al. 2016) have sizes of 2-3 $\mu \mathrm{m}$.

Most haptophytes large enough to be counted by microscopy were likely to be pooled into the "Nanoflagellates 3-20 $\mu \mathrm{m}$ " category (which comprised the majority of "Other" in Table S5), but part of them were identified as Phaeocystis colonies or coccolithophores. Colonial Phaeocystis occurred at stations 33, 35 and 36 , in the northern part of SWAS, at concentrations ranging from $510^{6}$ to $8910^{6}$ in terms of individual cells $\mathrm{L}^{-1}$ (data not shown). Coccolithophore concentrations ranged between 70 and 30000 cells $\mathrm{L}^{-1}$ throughout most of transect (Table S5), but reached a peak of $0.610^{6}$ cells $\mathrm{L}^{-1}$ at station 36 (SWAS). A total of 18 coccolithophore taxa were recorded; the dominant group were the "Unidentified small coccolithophores $(<10 \mu \mathrm{m})$ " (mostly Emiliania huxleyi and probably Gephyrocapsa spp.), but Calcidiscus leptoporus, Discophera tubifera, Syracosphaera pulcha and Umbellosphaera irregularis could be relatively abundant, in particular in the tropical Atlantic Ocean,.

The CHEMTAX dinoflagellate group (Fig. 7) was present in all the provinces but contributed less than $16 \%$ of the total Chl $a$ in the three size classes. Apart from the ubiquitous "Unidentified small dinoflagellates $(<20 \mu \mathrm{m})$ " and "Unidentified large dinoflagellates", a high diversity of dinoflagellate taxa (89 in total) was identified by microscopy in the tropical and subtropical Atlantic provinces, including Karlodinium spp. and several species of Ceratium, Dynophysis, Gonyaulax, Oxytoxum and Protoperidinium (Table S5). In contrast, only Dinophysis acuminata, Karlodinium spp., Prorocentrum balticum and Protoperidinium pacificum were present in SWAS, but at relatively high abundances. As mentioned for haptophytes, other CHEMTAX groups comprising cells of generally small size such as chlorophytes, pelagophytes and prasinophytes are likely to have been included in pooled microscopy categories such as the "Nanoflagellates 3-20 $\mu \mathrm{m}$ ".

\section{Size structure estimation of the phytoplankton community based on SFF and diagnostic pigment approaches}

The proportion of $\mathrm{Chl} a_{-}$pico $<3$ and $\mathrm{Chl} a_{-}$ $n+m \geq 3$ derived from the SFF (Fig. 3A) and the size distribution for each province resulting from the application of the VU and HI procedures can be seen in Figures $3 \mathrm{~B}$ and $\mathrm{C}$. The relationships between the proportion of Chl $a$ in the various size classes, as determined by SFF and the VU and HI methods (data not shown), were only significant (Table 6) between the nano+microphytoplankton from Hirata (f_n+m- 
$100 \cdot S$. Nunes et al.

Table 5. - Average $( \pm \mathrm{SD})$ values of the Chl $a$ contribution of the chemotaxonomic phytoplankton groups considered in this study for the various provinces. For province names, see the explanation in Figure 1.

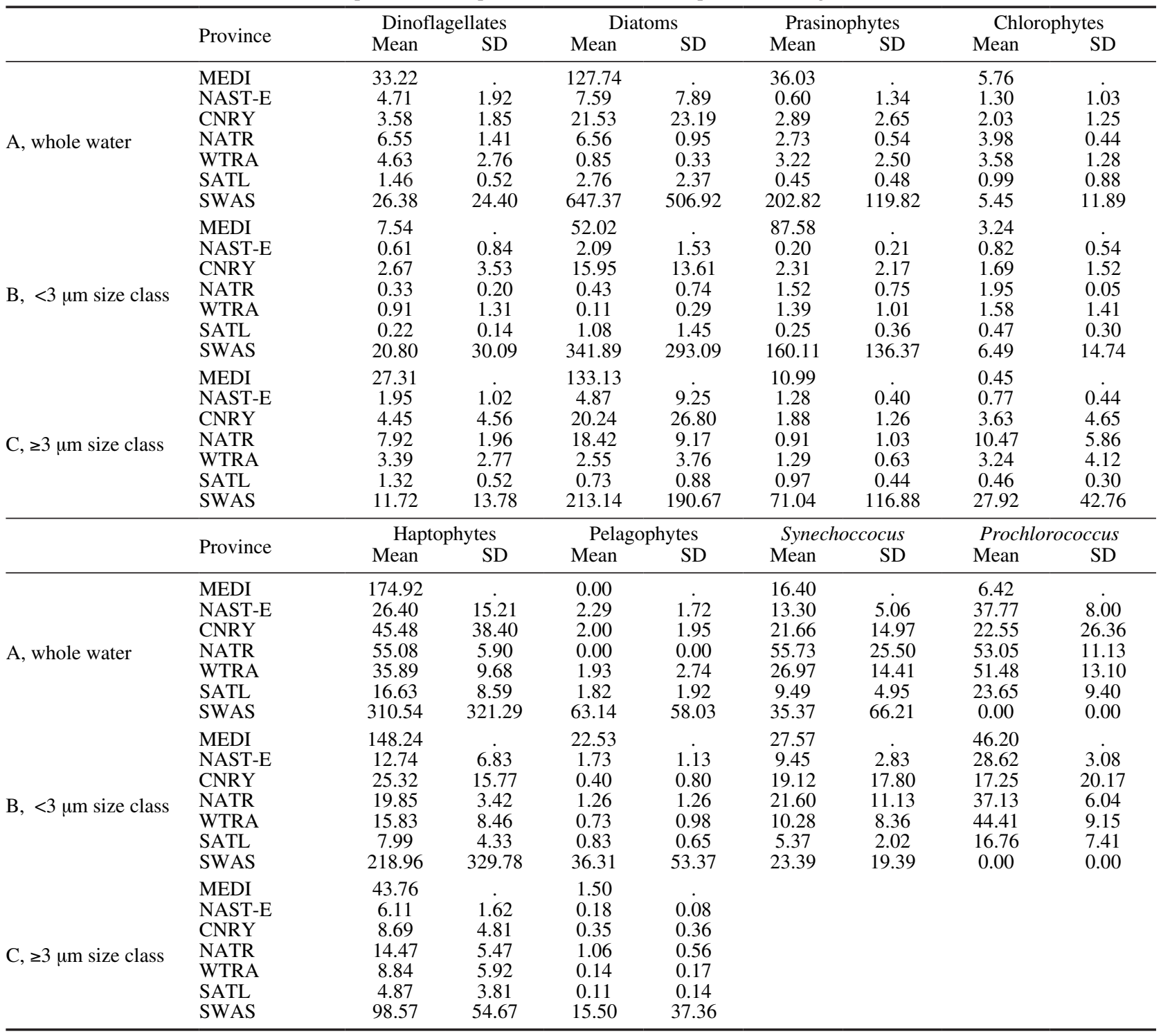

Table 6. - Parameters of the standard major axis regression lines (A) between the proportions of picophytoplankton and nano + microphytoplankton estimated by size-fractionated filtration (f pico $<3$ and $f \mathrm{n}+\mathrm{m} \geq 3$, respectively), and the corresponding estimates using the Vidussi et al. (2001) - Uitz et al. (2006) diagnostic pigment method (f_picoVU and f_n+mVU, respectively) and the Hirata et al. (2011) total Chl $a$-based method (f_picoHI and $\mathrm{f} \_n+m H I$, respectively); and $\mathrm{B}$, between the proportions of picophytoplankton and microphytoplankton estimated by the VU and HI methods (f picoVU vs. $f$ picoHI and f microVU vs. f microHI). "Low CI" and "High CI" are the 95\% confidence limits. Probability values of the test for slope $=1$ are based on the F-statistic. ns: non-significant, $* \mathrm{p}<0.005, * * \mathrm{p}<0.001, * * * \mathrm{p}<0.001$.

\begin{tabular}{|c|c|c|c|c|c|c|c|}
\hline Dependent variable & Independent variable & $\mathrm{r}^{2}$ & Slope & Low CI & High CI & Intercept & $\mathrm{p}$ for slope $=1$ \\
\hline \multicolumn{8}{|l|}{$\mathrm{A}$} \\
\hline f_picoVU & f_pico $<3$ & ns & & & & & \\
\hline f_picoHI & f_pico $<3$ & ns & & & & & \\
\hline f_n+mVU & f_n $+m \geq 3$ & ns & & & & & \\
\hline $\mathrm{f}_{\mathrm{B}} \mathrm{n}+\mathrm{mHI}$ & f_n $+m \geq 3$ & $0.17 *$ & 1.10 & 0.82 & 1.47 & 0.28 & $>0.99$ \\
\hline f_picoVU & f_picoHI & $0.25 * *$ & 1.11 & 0.84 & 1.46 & 0.01 & 0.45 \\
\hline f_microVU & f_microHI & $0.32 * * *$ & 0.82 & 0.63 & 1.06 & 0.09 & 0.13 \\
\hline
\end{tabular}

HI) and from the SFF (f_n+m $\geq 3$ ). However, there were significant linear relationships among the various estimates of the $\mathrm{Chl} a$ content in each size class with respect to total Chl $a$ (Fig. S5). The correlations between the VU and HI picophytoplankton (f_pico) and microphytoplankton (f_micro) proportions were significant, and the corresponding $95 \%$ confidence limits for the slope straddled unity (Table 6). The SI index (log-transformed) was weakly correlated with Chl $a$ _tot and with f_pico<3 (Fig. S6A, B). 


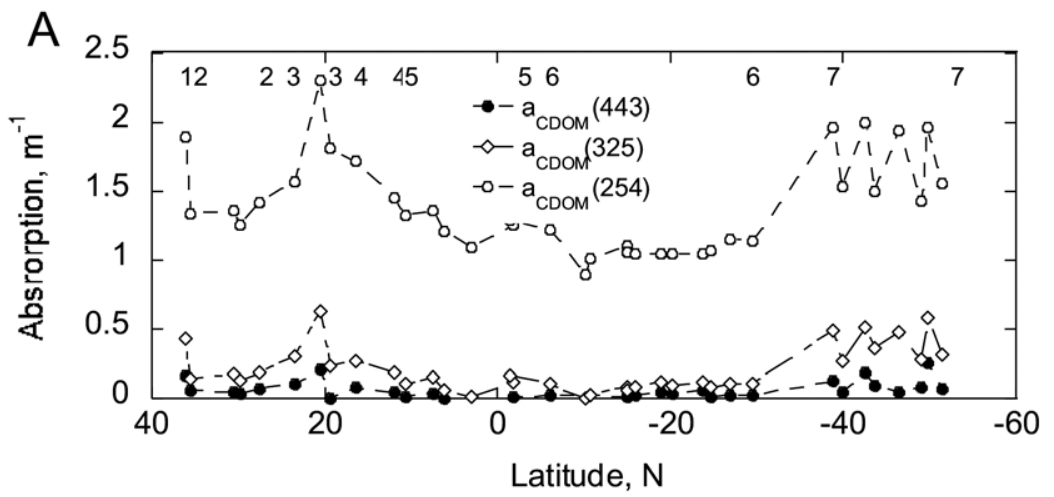

B

$$
\begin{aligned}
& ---\log \left[a_{\operatorname{CDOM}}(443)\right] \\
& -0-\log \left[a_{\operatorname{CDOM}}(325)\right]
\end{aligned} \longrightarrow \log \left[a_{\operatorname{CDOM}}(254)\right]
$$

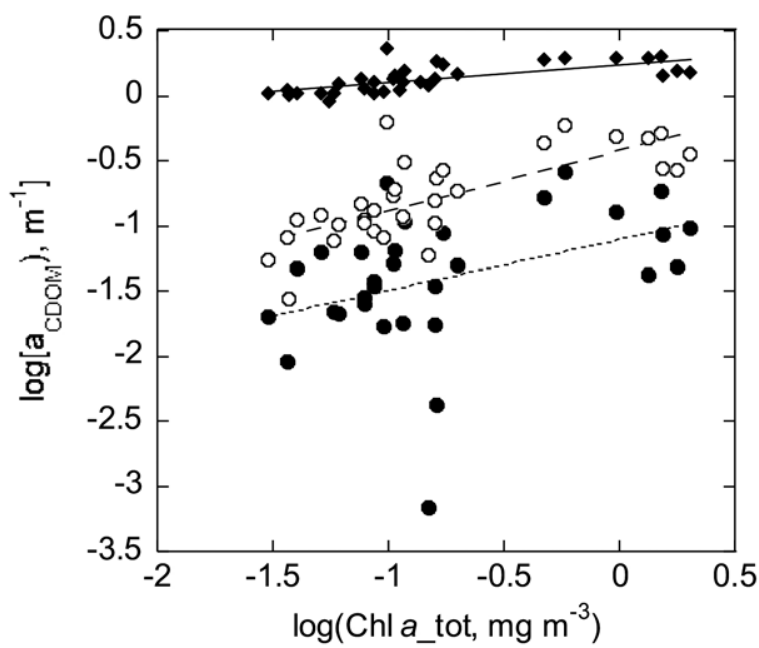

Fig. 8. - A, latitudinal variation of $\mathrm{a}_{\mathrm{CDOM}}(443), \mathrm{a}_{\mathrm{CDOM}}(325)$ and $\mathrm{a}_{\mathrm{CDOM}}(254)\left(\mathrm{m}^{-1}\right)$ along the TransPEGASO transect; $\mathrm{B}$, relationships of $\mathrm{a}_{\mathrm{CDOM}}(443), \mathrm{a}_{\text {CDOM }}(325)$ and $\mathrm{a}_{\text {CDOM }}(254)$ with Chl $a_{-}$tot $\left(\mathrm{mg} \mathrm{m}^{-3}\right)$. The equations of the lines are $\log \left[\mathrm{a}_{\mathrm{CDOM}}(443)\right]=0.39 * \log \left(\mathrm{Chl} a \_\right.$tot $)-1.11$, $\mathrm{n}=31, \mathrm{r}^{2}=0.16, \mathrm{p}<0.05 ; \log \left[\mathrm{a}_{\mathrm{CDOM}}(325)\right]=0.46 * \log \left(\mathrm{Chl} a_{-}\right.$tot $)-0.42, \mathrm{n}=31, \mathrm{r}^{2}=0.55, \mathrm{p}<0.0001$ and $\log \left[\mathrm{a}_{\mathrm{CDOM}}(254)\right]=0.14 * \log \left(\mathrm{Chl} a_{-}\right.$tot $)-0.24$, $\mathrm{n}=35, \mathrm{r}^{2}=0.47, \mathrm{p}<0.0001$.

\section{Variation of CDOM and light absorption properties}

Average CDOM across the transect ranged from $0.02 \mathrm{~m}^{-1}$ (WTRA) to $0.16 \mathrm{~m}^{-1}$ (MEDI) at $443 \mathrm{~nm}\left[\mathrm{a}_{\mathrm{C}}\right.$ DOM(443)], from $0.09 \mathrm{~m}^{-1}$ (SATL) to $0.43 \mathrm{~m}^{-1}$ (MEDI) at $325 \mathrm{~nm}\left[\mathrm{a}_{\mathrm{CDOM}}(325)\right]$ and from $1.07 \mathrm{~m}^{-1}$ (SATL) to $1.90 \mathrm{~m}^{-1}$ (MEDI and CNRY) at $254 \mathrm{~nm}$ [a $\left.\mathrm{a}_{\mathrm{CDOM}}(254)\right]$ (Fig. 8A, Table 7). There was a significant correlation between CDOM absorption and Chl $a_{-}$tot (Fig. 8B) $\left[\mathrm{n}=31, \mathrm{r}^{2}=0.16, \mathrm{p}<0.05\right.$ for $\mathrm{a}_{\mathrm{CDOM}}(443) ; \mathrm{n}=31, \mathrm{r}^{2}=0.55$, $\mathrm{p}<0.0001$ for $\mathrm{a}_{\mathrm{CDOM}}(325) ; \mathrm{n}=35, \mathrm{r}^{2}=0.47, \mathrm{p}<0.0001$ for $\left.\mathrm{a}_{\mathrm{CDOM}}(254)\right]$. The ratio between $\mathrm{a}_{\mathrm{CDOM}}$ and Chl a_tot showed the lowest values in MEDI and SWAS, as shown in Figure $\mathrm{S} 8$ for $\mathrm{a}_{\mathrm{CDOM}}(254)$.

At $443 \mathrm{~nm}, \mathrm{CDOM}$ was in general the largest component of total non-water light absorption, in particular at the MEDI station and in some of the low Chl $a$ provinces (Fig. 9). The average CDOM contribution ranged from $74 \%$ in MEDI and $69 \%$ in NATR to $34 \%$ in WTRA, while phytoplankton absorption accounted for $47 \%$ of the total in WTRA and SWAS and for $18 \%$ to $24 \%$ in the other provinces (Fig. 9, Table 7).

When the whole data set was considered, phytoplankton absorption at $443 \mathrm{~nm}\left[\mathrm{a}_{\mathrm{ph}}(443)\right]$ showed a significant power relationship with $\mathrm{Chl} a$ _tot [Fig. $10 \mathrm{~A} ; \mathrm{a}_{\mathrm{ph}}(443)=0.098+\mathrm{Chl} a \_$tot $^{\wedge} 0.88, \mathrm{n}=37 ; \mathrm{r}^{2}=0.93$, $\mathrm{p}<0.0001]$. The Chl $a$-specific absorption by phytoplankton $\left[\mathrm{a}_{\mathrm{ph}} *(443)\right]$ appeared to decrease with increasing $\mathrm{Chl}$ a_tot (Fig. 10B, Table 7) and increased with increasing package index Qa*(443) (Fig. 10C). However, these relationships are difficult to evaluate statistically due to shared measurements in the dependent and independent variables (Dunlap et al. 1997). On the other hand, Qa*(443) was not correlated with Chl $a \_$tot (data not shown).

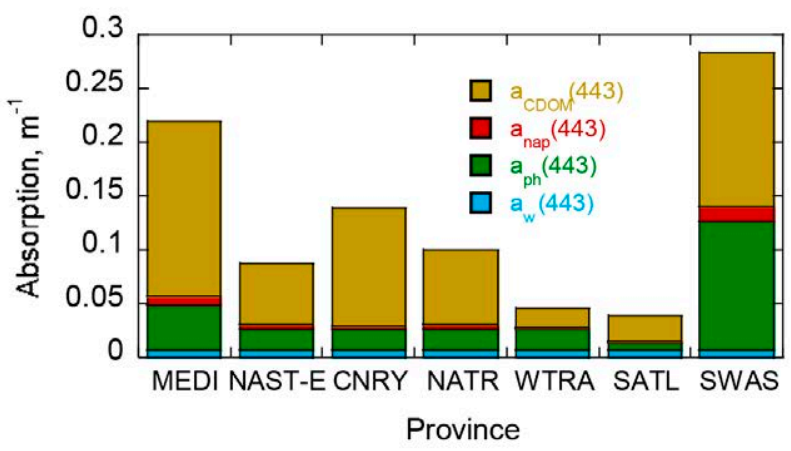

Fig. 9. - Average contribution to total light absorption $\left(\mathrm{m}^{-1}\right)$ at 443 nm of CDOM [a $\left.\operatorname{aDOM}_{\mathrm{CDO}}(443)\right]$, non-phytoplankton particles [a $\left.\mathrm{a}_{\text {nap }}(443)\right]$, phytoplankton $\left[\mathrm{a}_{\mathrm{ph}}(443)\right]$ and water $\left(\mathrm{a}_{\mathrm{w}}\right)$ for the different provinces. 

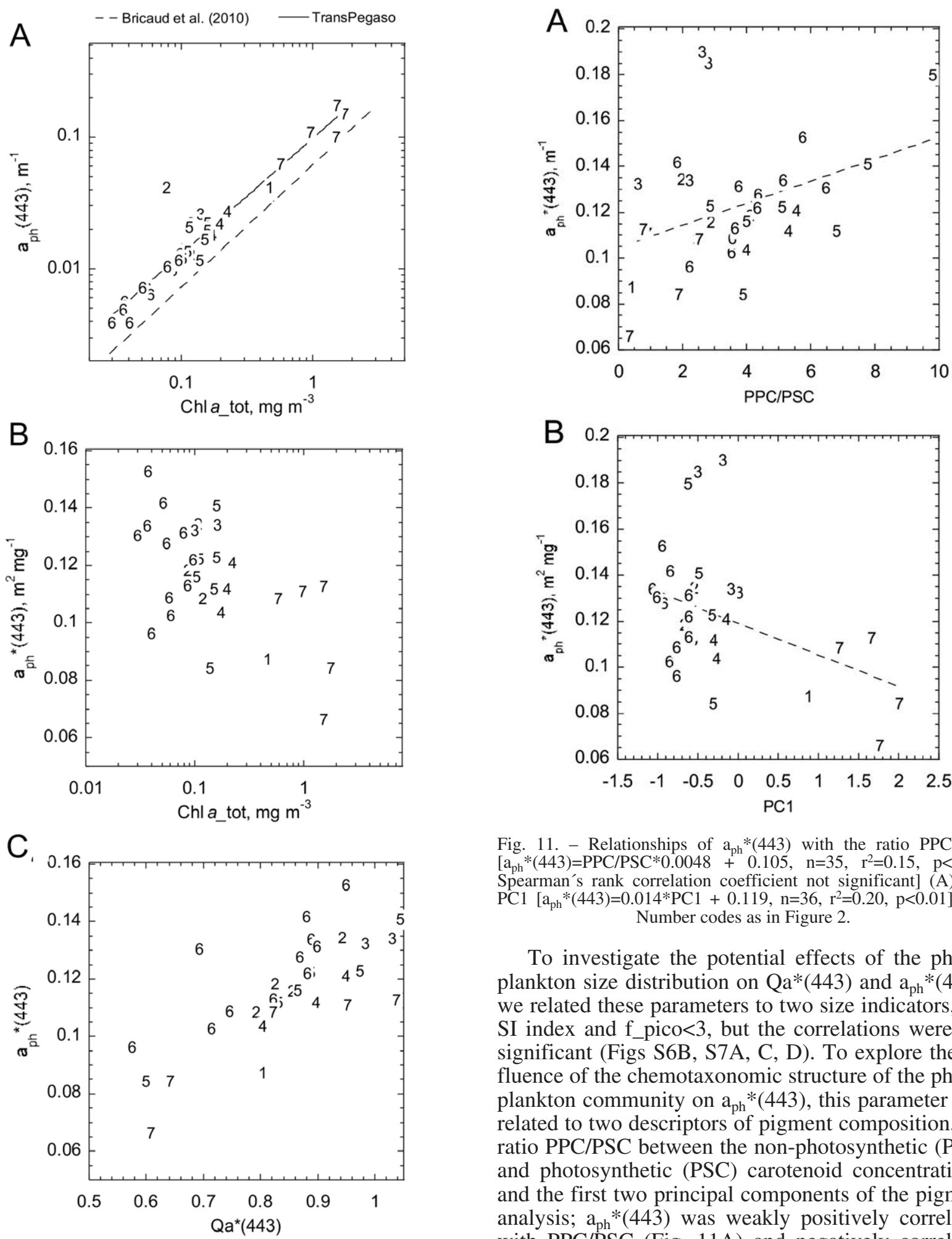

Fig. 10. - Relationship of parameters of phytoplankton absorption with $\mathrm{Chl} a$ _tot and the package index [Qa*(443)]. The units of the variables are $\mathrm{mg} \mathrm{m}^{-3}$ for Chl $a_{-}$tot, $\mathrm{m}^{-1}$ for $\mathrm{a}_{\mathrm{ph}}(443)$ and $\mathrm{a}_{\mathrm{pig}}(443)$, and $\mathrm{m}^{2} \mathrm{mg}^{-1}$ for $\mathrm{a}_{\mathrm{ph}} *(443)$. The numbers within the graph indicate the provinces (see the explanation of Figure 1 for abbreviations): 1, MEDI; 2, NAST-E; 3, CNRY; 4, NATR; 5, WTRA; 6, SATL; 7. SWAS. A, power regression of $\mathrm{a}_{\mathrm{ph}}(443)$ on Chl $a$ tot; the equations for TransPEGASO are $\mathrm{a}_{\mathrm{ph}}(443)=0.098^{*} \mathrm{Chl} \quad a_{-}$tot $^{\wedge} 0.88$, $\mathrm{r}^{2}=0.93$, and those for Bricaud et al. $(2010)$ are $\mathrm{a}_{\mathrm{ph}}(440)=0.0617 * \mathrm{Chl}$ $a$ tot $^{\wedge} 0: 93$. B, relationship between $\mathrm{a}_{\mathrm{ah}} *(443)$ and Chl $a$ tot. C, relationship between $\mathrm{a}_{\mathrm{ph}} *(443)$ and $\mathrm{Qa} *(443)$. Number codes as in Figure 2.

Fig. 11. - Relationships of $\mathrm{a}_{\mathrm{ph}} *(443)$ with the ratio PPC/PSC $\left[\mathrm{a}_{\mathrm{ph}} *(443)=\right.$ PPC/PSC $* 0.0048+0.105, \quad \mathrm{n}=35, \quad \mathrm{r}^{2}=0.15, \quad \mathrm{p}<0.05$; Spearman's rank correlation coefficient not significant] (A) and PC1 $\left[\mathrm{a}_{\mathrm{ph}} *(443)=0.014 * \mathrm{PC} 1+0.119, \mathrm{n}=36, \mathrm{r}^{2}=0.20, \mathrm{p}<0.01\right]$ (B). Number codes as in Figure 2.

To investigate the potential effects of the phytoplankton size distribution on $\mathrm{Qa} *(443)$ and $\mathrm{a}_{\mathrm{ph}} *(443)$, we related these parameters to two size indicators, the SI index and f_pico $<3$, but the correlations were not significant (Figs S6B, S7A, C, D). To explore the influence of the chemotaxonomic structure of the phytoplankton community on $\mathrm{a}_{\mathrm{ph}} *(443)$, this parameter was related to two descriptors of pigment composition, the ratio PPC/PSC between the non-photosynthetic (PPC) and photosynthetic (PSC) carotenoid concentrations, and the first two principal components of the pigment analysis; $a_{\mathrm{ph}} *(443)$ was weakly positively correlated with PPC/PSC (Fig. 11A) and negatively correlated with PC1 (Fig. 11B; $\mathrm{r}_{\mathrm{s}}{ }^{2}=0.13, \mathrm{p}<0.05$ ); the relationship with PC2 (data not shown) was not significant.

\section{DISCUSSION}

\section{Oceanographic characteristics of surface waters}

Based on the observed Chl a concentrations, the oceanographic provinces encountered during 
Table 7. - Average ( \pm SD) values of the CDOM absorption at $443 \mathrm{~nm}\left[\mathrm{a}_{\mathrm{CDOM}}(443)\right], 325 \mathrm{~nm}\left[\mathrm{a}_{\mathrm{CDOM}}(325)\right]$ and $254 \mathrm{~nm}\left[\mathrm{a}_{\mathrm{CDOM}}(254)\right]$ and of the percentage contribution to total non-water absorption at $443 \mathrm{~nm}$ by CDOM [a $\left.\mathrm{a}_{\mathrm{CDOM}}(443)\right]$, non-phytoplankton particles [a $\left.\mathrm{a}_{\text {nap }}(443)\right]$ and phytoplankton $\left[\mathrm{a}_{\mathrm{ph}}(443)\right]$ for the different provinces. $\mathrm{a}_{\mathrm{pig}}(443)$ is the absorption of pigments in solution at $443 \mathrm{~nm}$; $\mathrm{a}_{\mathrm{ph}} *(443)$ and $\mathrm{a}_{\text {pig }} *(443)$ are the Chl $a$ _tot-specific values corresponding respectively to $\mathrm{a}_{\mathrm{ph}}(443)$ and $\mathrm{a}_{\mathrm{pig}}(443)$. Qa* (443) is the package index.

\begin{tabular}{|c|c|c|c|c|c|c|c|c|c|c|c|c|}
\hline \multirow[b]{2}{*}{ Province } & \multicolumn{2}{|c|}{$\mathrm{a}_{\mathrm{CDOM}}(443)$} & \multicolumn{2}{|c|}{$\mathrm{a}_{\mathrm{CDOM}}(325)$} & \multicolumn{2}{|c|}{$\mathrm{a}_{\mathrm{CDOM}}(254)$} & \multicolumn{2}{|c|}{$a_{p h}(443)$} & \multicolumn{2}{|c|}{$\mathrm{a}_{\mathrm{ph}} *(443)$} & \multicolumn{2}{|c|}{$a_{p i g}(443)$} \\
\hline & Mean & SD & Mean & SD & Mean & SD & Mean & SD & Mean & SD & Mean & SD \\
\hline MEDI & 0.163 & & 0.431 & & 1.901 & & 0.041 & & 0.088 & & 0.025 & \\
\hline NAST-E & 0.054 & 0.013 & 0.159 & 0.026 & 1.343 & 0.066 & 0.020 & 0.015 & 0.119 & 0.011 & 0.007 & 0.001 \\
\hline CNRY & 0.109 & 0.106 & 0.388 & 0.208 & 1.897 & 0.368 & 0.019 & 0.005 & 0.160 & 0.031 & 0.008 & 0.002 \\
\hline NATR & 0.068 & 0.026 & 0.226 & 0.059 & 1.589 & 0.189 & 0.020 & 0.003 & 0.112 & 0.009 & 0.012 & 0.002 \\
\hline WTRA & 0.018 & 0.014 & 0.103 & 0.056 & 1.258 & 0.094 & 0.020 & 0.002 & 0.125 & 0.029 & 0.009 & 0.002 \\
\hline SATL & 0.029 & 0.016 & 0.087 & 0.027 & 1.07 & 0.081 & 0.007 & 0.003 & 0.124 & 0.017 & 0.004 & 0.001 \\
\hline \multirow[t]{3}{*}{ SWAS } & 0.114 & 0.075 & 0.410 & 0.121 & 1.739 & 0.249 & 0.119 & 0.044 & 0.097 & 0.021 & 0.084 & 0.035 \\
\hline & \multicolumn{2}{|c|}{$\mathrm{a}_{\mathrm{pig}} *(443)$} & \multicolumn{2}{|c|}{$\mathrm{Qa} *(443)$} & \multicolumn{2}{|c|}{$\% \mathrm{a}_{\mathrm{CDOM}}(443)$} & \multicolumn{2}{|c|}{$\% \mathrm{a}_{\text {nap }}(443)$} & \multicolumn{2}{|c|}{$\% \mathrm{a}_{\mathrm{ph}}(443)$} & & \\
\hline & Mean & SD & Mean & SD & Mean & SD & Mean & SD & Mean & SD & & \\
\hline MEDI & 0.052 & & 0.804 & & 76.3 & & 4.4 & & 19.3 & & & \\
\hline NAST-E & 0.067 & 0.002 & 0.854 & 0.065 & 72.6 & 11.6 & 3.9 & 3.0 & 23.5 & 8.8 & & \\
\hline CNRY & 0.065 & 0.003 & 1.006 & 0.033 & 63.0 & 42.3 & 4.4 & 5.0 & 32.6 & 37.3 & & \\
\hline NATR & 0.060 & 0.002 & 0.884 & 0.073 & 73.8 & 9.9 & 2.9 & 0.7 & 23.3 & 9.2 & & \\
\hline WTRA & 0.065 & 0.006 & 0.867 & 0.152 & 50.1 & 11.0 & 2.9 & 1.3 & 47.0 & 10.3 & & \\
\hline SATL & 0.072 & 0.010 & 0.811 & 0.114 & 74.7 & 11.3 & 3.4 & 1.6 & 21.9 & 10.1 & & \\
\hline SWAS & 0.061 & 0.012 & 0.813 & 0.188 & 48.6 & 22.7 & 5.7 & 2.5 & 45.7 & 21.2 & & \\
\hline
\end{tabular}

TransPEGASO were operationally classified into a low Chl $a\left(<0.5 \mathrm{mg} \mathrm{m}^{-3}\right)$ and a high Chl $a\left(\geq 0.5 \mathrm{mg} \mathrm{m}^{-3}\right)$ category. The first or "oligotrophic" group includes waters of CNRY and of the Tropical and Subtropical Atlantic gyres (NAST-E, NATR, WTRA and SATL), and the second or "eutrophic" one includes SWAS and the single MEDI station. Nutrient concentrations supported this categorization. Average nitrate (Table 3) approached or exceeded $1 \mu \mathrm{M}$ only in MEDI $(0.8 \mu \mathrm{M})$ and SWAS $(4.1 \mu \mathrm{M})$, average silicate ranged between 0.3 and $0.7 \mu \mathrm{M}$ except in WTRA $(1.1 \mu \mathrm{M})$, and average phosphate was lower than $0.12 \mu \mathrm{M}$ in all provinces except SWAS.

During our survey, the CNRY stations could be considered as oligotrophic, although the province may be affected by sporadic offshore filaments of nutrient-rich waters originating in the seasonal NW African coastal upwelling (Longhurst, 2007, Menna et al. 2016). The MEDI sample was taken in the Alborán Sea, a zone of strong mesoscale variability, in which the influence of the Atlantic jet coming through the Strait of Gibraltar and wind forcing cause coastal upwelling and other hydrographical structures associated with nutrient fertilization and relatively high Chl $a$ concentrations (Tintoré et al. 1991, Macías et al. 2007). The eutrophic condition of SWAS, already described in previous studies (Gibb et al. 2000, Vega-Moreno et al. 2012), reflects the strong hydrodynamism of this region, subjected to tidal mixing and the interactions of the Brazil and Malvinas Currents with the waters over the continental shelf. During our study, the influence of the Sub-Antarctic Surface Waters associated with the Malvinas Current were reflected in the temperature and salinity minima (Fig. 2A) and the high concentrations of nutrients (Fig. 2B, C) found in the southern part of the transect.

As discussed below, the differences in composition and size structure of the phytoplankton community were mainly linked to changes in Chl $a$ _tot concentration. However, a substantial part of the pigment variability encountered during the cruise was associ- ated with photoacclimation responses. The morningafternoon changes of Ddx/LHC (Fig. 4A) and the positive correlation of this ratio with solar radiation (Fig. S2A) may reflect the photoprotective role of Ddx, as timescales for pigment synthesis are of minutes to hours for photoprotective carotenoids (PPCs) and of hours to days for light-harvesting pigments (Ferris and Christian 1991, Bidigare et al. 2014). Both high light and low nutrient conditions (Eisner et al. 2003) were likely to be responsible for the relative increases in the proportion of PPC/PSC (and PPC/Chl $a_{-}$tot, data not shown) found in the oligotrophic provinces of our transect (Fig. 4B).

Comparable results concerning pigment and phytoplankton distributions have been reported in other studies. Gibb et al. (2000) sampled the Atlantic Ocean between $50^{\circ} \mathrm{N}$ and $50^{\circ} \mathrm{S}$ and, based on HPLC analyses, recorded a dominance of PSCs to PPCs from $50-30^{\circ} \mathrm{N}$, to the north of the start of our survey, to $35-45^{\circ} \mathrm{S}$. Acevedo-Trejos et al. (2018) used in situ data and traitbased modelling to find an increase of average phytoplankton size and other parameters when moving from low to high latitudes.

\section{Size-fractionated Chl $\boldsymbol{a}$ and comparison between phytoplankton size structure estimates}

The VU and HI algorithms (Table 2) have been widely used to infer the size structure of phytoplankton communities (Taylor et al. 2011, Zeng et al. 2018); however, verification has been limited (see Brewin et al. 2014). In our data set, there was no correlation between the proportion of picophytoplankton estimated by VU or HI, and that obtained by SFF (Table 6). It must be noted, however, that in spite of the lack of relationship of the Chl $a$ proportions, there was a significant correlation between the Chl $a$ concentrations allocated to each size class by the different methods (Fig. S5); this arises (Goodwin and Leech 2006) because, other things being comparable, the value of the correlation increases with 
increasing variability among the observations, and Chl_ $a$ concentrations are more variable than proportions (coefficients of variation ranged from $18 \%$ to $132 \%$ for proportions, and from $301 \%$ to $710 \%$ for Chl $a$ concentrations). Both the VU and HI approaches predicted a lower proportion of small cells than that found in the filtration results (Fig. 3A), as found by Brewin et al. (2014). Apart from possible methodological issues (see below), this discrepancy may have arisen because our SFF used a limit of 3 $\mu \mathrm{m}$ between the small and large categories instead of the $2 \mu \mathrm{m}$ threshold of the VU and HI approximations, so the f_pico $<3$ fraction of Figure $3 \mathrm{~A}$ includes part of the nanophytoplankton size class of the other methods. This difference is not trivial, as suggested by the extensive list of phytoplankton taxa with sizes ranging from $<2 \mu \mathrm{m}$ to $3 \mu \mathrm{m}$ (Vaulot et al. 2008). Indeed, some groups generally considered as nanoplankton, such as haptophytes and pelagophytes, may have most of their cells in the 2 to $3 \mu \mathrm{m}$ category (Cabello et al 2016, Fig. S3) or, as found for the haptophytes in some samples, may even include forms $<2 \mu \mathrm{m}$. In our work, for example, the proportion of haptophytes in Chl $a \_$pico $<3$ was quite high in all the provinces, and pelagophytes and prasinophytes in this size class were also well represented in MEDI and SWAS (Fig. 7). These findings agree with those of other studies indicating the relevance of organisms of these groups in the $<3 \mu \mathrm{m}$ size range (Massana 2011) and highlight the need to reach a wide operational agreement concerning thresholds for the smallest phytoplankton size class, which we suggest could be made for a larger size limit, perhaps $5 \mu \mathrm{m}$, as adopted by Mousseau et al. (2001), based on the obervation that this is the size of the smallest particles that mesozooplankton can efficiently graze (Fortier et al. 1994). In addition, a larger size limit would contribute to minimize experimental artefacts (e.g. due to clogging of filters).

All size distributions (Fig. 3) showed a greater proportion of nano- and microphytoplankton cells in MEDI and SWAS (together with NATR for the SFF data) than in the other provinces. For SWAS, however, there was a clear discrepancy between size classes estimated by SFF and by pigment algorithms. The small contribution of nano- + microphytoplankton determined by size fractionation (Fig. 3a) contrasted with the higher proportions derived from the VU and HI models (Fig. 3B, C), and with the high contribution of diatom Chl $a$ in all the size classes (Fig. 7). The total Chl $a$ (SDP) estimated by the VU algorithm was in good agreement with Chl $a$ _tot from HPLC (SD$\mathrm{P}=0.96 *$ Chl a_tot $-0.01, \mathrm{n}=4 \overline{1}, \mathrm{r}^{2}=0.88, \mathrm{p}<0.0001$, Fig. S3B), indicating that the discrepancy stemmed from a misallocation of part of the Chl_a pool between the different size classes. Optical microscopy observations showed relatively low concentrations of nano- and micro-sized diatoms in several SWAS stations, in which the diatom contribution to Chl $a$ _tot was high according to CHEMTAX (Tables 5 and $\bar{S} 5$ ). This discrepancy is very probably due to the presence of Parmales and of picoplankton-sized diatoms such as Minidiscus, which could have been part of the high picophytoplankton densities found in SWAS. As the VU approach to estimating taxonomic composition through diagnostic pigments is based on the premise that organisms with diatom-type pigments belong to the microplankton size class, picophytoplankton forms with this pigment signature will be incorrectly classified as microphytoplankton.

Estimation of phytoplankton size based on pigment composition is challenging because many pigments are shared by small and large phytoplankton forms (Roy et al. 2011). In this context, application of CHEMTAX to HPLC-determined pigment concentrations allows for a finer classification of phytoplankton chemotaxonomic groups than approaches based on simpler algorithms. Methods such as that of Hirata et al. (2011) based on the relationship of the proportion of functional groups or size classes with total Chl $a$ are influenced by the phytoplankton composition in the data sets used to derive the model parameters. On the other hand, filtration procedures have their own problems (e.g. due to cell breakage), especially when $\mathrm{Chl} a$ concentrations are low (Brewin et al. 2014). It has also been noted that the size fractionation technique tends to overestimate the smaller fractions because of the defective retention of larger cells with non-spherical shapes (Murphy and Haugen 1985).

\section{The phytoplankton community in the oligotrophic Atlantic Ocean}

The dominance of Zea and DV-Chl $a$ in the oligotrophic provinces agrees with the prominent contribution of Synechoccus and Prochlorococcus to Chl $a \_$tot and with abundance and biomass estimates derived from flow cytometric counts (Fig. 5B; see also Zamanillo et al. 2019). However, our SFF results indicate that pore sizes of 2 or $3 \mu \mathrm{m}$ may retain a part of the Synechococcus population, suggesting the need for caution when interpreting fractionation data. Due to their small size, both Prochlorococcus and Synechococcus have relatively high surface-to-volume ratios and can thrive in nutrient-poor situations, although Prochlorococcus seems to be associated with more oligotrophic conditions than Synechococcus spp (Latasa et al. 2010). This observation could explain the higher relative importance of Synechococcus in CNRY, which may be affected by occasional upwelling filaments (Menna et al. 2016). The most abundant eukaryotic pigments corresponded in general to the haptophytes, which include both nano- and picoplankton forms (Vaulot et al. 2008). However, diatoms were important in all the size classes of CNRY, although high cell counts at some stations were not reflected into comparatively high Chl $a$ concentrations, an observation that could be due, at least in part, to the small cell size of the dominant taxa (Chaetoceros spp. and thin Pseudo-nitzschia spp.). Due to their elongated shape, the thin Pseudo-nitzschia spp. would likely pass through $3-\mu \mathrm{m}$ pore filters, helping to explain the high contribution of diatom pigments in the f_pico $<3$ fraction. 


\section{The phytoplankton community in the high $\mathrm{Chl} a$ regions}

CHEMTAX results for MEDI and SWAS indicated that the main contributors to all the size classes were diatoms, haptophytes and prasinophytes (Fig. 7). Prokaryotic phytoplankton, probably outcompeted by other groups (Partensky et al. 1999), accounted for only a small proportion of Chl $a_{-}$tot in both provinces. The absence of Prochlorococcus in SWAS agrees with a lower temperature limit of $15^{\circ} \mathrm{C}$ for this genus (Johnson et al. 2006). As mentioned above, the strikingly high proportion of diatom $\mathrm{Chl} a$ in the pico<3 class and the discrepancy between the microplankton contribution determined by size fractionation and estimated by the VU and HI models in SWAS could be explained by the presence of Parmales and picoplankton-sized diatoms such as Minidiscus, which appear to be more common than previously considered (Leblanc et al. 2018). These findings support the observations of Ferreira et al. (2013), who noted that the size of phytoplankton cells in Patagonian waters tended to be smaller than that found in other areas with a similar Chl $a$ concentration.

Our microscopic observations revealed that the most abundant diatom taxa were several Chaetoceros species, small Thalassiosira $(<20 \mu \mathrm{m})$ and Eucampia spp., whereas haptophytes were partially represented by Phaeocystis colonies and coccolithophores. García et al. (2008), in their study of a spring cruise in the Patagonian Shelf, noted the occurrence of large diatom and dinoflagellate blooms, accompanied by nanoflagellates including Phaeocystis cf. antarctica. Similarly, Ferreira et al. (2013) mentioned the dominance of nanoplankton-sized Thalassiosira spp. in the same area in spring, while Souza et al. (2012) studied a summer bloom dominated by the coccolithophore Emiliania huxleyi, the haptophyte Phaeocystis antarctica and other microalgal taxa.

\section{Variability of CDOM and phytoplankton absorption}

Except in SWAS, $\mathrm{a}_{\mathrm{CDOM}}(443)$ accounted for more than $50 \%$ of total non-water absorption (Table 7), in agreement with previous studies (Nelson et al. 1998, Gonçalves-Araujo et al. 2018); the relatively high $\mathrm{a}_{\mathrm{C}}$ DOM(443) contribution in the MEDI sample coincides with the findings of Pérez et al. (2016). The relatively high values of the ratio $\mathrm{a}_{\mathrm{CDOM}}(254) / \mathrm{Chl} a$ _tot in the oligotrophic provinces (Fig. S8) may be due, at least in part, to a reduction of the microbial processing of DOC caused by nutrient limitation (Thingstad et al. 1997, Romera-Castillo et al. 2013). The positive relationship between $\mathrm{a}_{\mathrm{CDOM}}$ and $\mathrm{Chl} a$ _tot, as other authors have noted (Nelson et al. 1998, Xing et al 2014), suggests CDOM production by phytoplankton, which are the ultimate source of dissolved organic matter in the open sea. Likewise, the low $\mathrm{a}_{\mathrm{CDOM}}$ values at WTRA stations, the most distant from the continents, could be indicative of a terrestrial contribution to the $\mathrm{a}_{\mathrm{CDOM}}$ signal of regions closer to land.
Similarly to Bricaud et al. (2004) and others, we found that $\mathrm{a}_{\mathrm{ph}}(443)$ could be expressed as a power function of Chl $a\left(\mathrm{a}_{\mathrm{ph}}(443)=0.098^{*} \mathrm{Chl} a\right.$ tot $^{\wedge} 0.88$, $\mathrm{n}=37 ; \mathrm{r}^{2}=0.93, \mathrm{p}<0.0001$; Fig. 10A); the presence of outliers could be due to natural variations or to analytical artefacts. The exponent of the relationship was similar to that determined by Bricaud et al (2010) for southern Pacific waters $\left[\mathrm{a}_{\mathrm{ph}}(440)=0.0617 * \mathrm{Chl}\right.$ $a$ _tot $\left.{ }^{\wedge} 0: 93\right]$. The decrease in the Chl $a$ specific absorption coefficient, $\mathrm{a}_{\mathrm{ph}}{ }^{*}(443)$ with increasing Chl $a$ and the positive relationship between $\mathrm{a}_{\mathrm{ph}} *(443)$ and Qa*(443), as seen in Figure 10B and C, are a common finding in absorption studies because, apart from potential statistical artefacts due to common variables in the calculation of ratios (Dunlap et al. 1997), high Chl $a$ values tend to be associated with a lower contribution of accessory pigments and with larger cells (and therefore a higher package effect due to size) (Bricaud et al. 1995). We found (Fig. 10C) a positive relationship between $\operatorname{aph}^{*}(443)$ and the package effect index Qa*(443), suggesting the occurrence of package effects.

The lack of correlation of both Qa*(443) and $\mathrm{a}_{\mathrm{ph}}{ }^{*}$ (443) with SI and with f_pico<3 (Fig. S7), and the relationships of $\mathrm{a}_{\mathrm{ph}}(443)$, negative with PC1 (Fig. 11A) and positive with PPC/PSC (Fig. 11B), suggest that the variation of $\mathrm{Qa}^{*}(443)$ and $\mathrm{a}_{\mathrm{ph}} *(443)$ in our data set was mainly related to the chemotaxonomic structure (pigment composition) and photoacclimation processes (changes in the intracellular pigment concentration) of the different phytoplankton communities and that any potential effects of cell size were ultimately masked. This contrasts with findings of other works that showed that the size structure of the phytoplankton algal population was a major factor explaining variability of $\mathrm{a}_{\mathrm{ph}} *(443)$ in surface ocean waters (e.g. Ciotti et al. 2002, Bricaud et al. 2004, Ferreira et al. 2013, Wang et al. 2014). One of the reasons for the discrepancy may be simply that the range of total $\mathrm{Chl} a$ concentrations considered in these studies is much wider and includes many measurements with higher Chl $a$ concentrations (e.g. exceeding $5-10 \mathrm{mg} \mathrm{m}^{-3}$ ) than those in our data set (our maximum Chl $a$ _tot was $2.4 \mathrm{mg} \mathrm{m}^{-3}$ ); as discussed above, for a given amount of scatter of the dependent variable, the value of the correlation increases with increasing variability among the observations of the independent variable (Goodwin and Leech 2006). On the other hand, our outcomes are in line with those of other studies where, in addition to the major contribution of size structure, either changes in intracellular pigment concentration or variations in pigment composition were also found to be important factors shaping $\mathrm{a}_{\mathrm{ph}}$ *(443) (Brunelle et al. 2012, Ferreira et al. 2017, Kheireddine et al. 2018); it can be noted also that these works used a $\mathrm{Chl} a$ concentration range rarely exceeding $5 \mathrm{mg} \mathrm{m}^{-3}$.

\section{CONCLUSIONS}

Our findings highlight the taxonomic differences, in terms of both species and pigment composition, 
between phytoplankton communities of subtropicaltropical and temperate waters. While haptophytes were abundant everywhere, Prochlorococcus and Synecoccoccus dominated in the tropical and subtropical Atlantic, and diatoms were important in MEDI and SWAS.

Concerning phytoplankton size distributions, our results agree with those of Brewin et al. (2014) and others, and emphasize the need to combine different methods, including HPLC analyses associated with chemotaxonomic algorithms, SFF and flow cytometric and microscopic observations, to reach a suitable characterization of the size structure of phytoplankton communities.

In SWAS, both the VU and HI algorithms showed a high proportion of nano- and microphytoplankton, in contrast with the results of the SFF, which indicated dominance of the $<3 \mu \mathrm{m}$ class; in addition, CHEMTAX detected a high presence of diatoms in the Chl $a \_$pico $<3$ class of this province. The scanning electron confirmed the presence of picoplanktonic-sized cells of the diatom Minidiscus sp. and of Parmales (a group sharing the pigment composition with the diatoms), cautioning against the routine assignation of diatom-type pigments to microphytoplankton.

Absorption by CDOM was the dominant component of total non-water absorption in the water column; $\mathrm{a}_{\mathrm{CDOM}}(443), \mathrm{a}_{\mathrm{CDOM}}(325)$ and $\mathrm{a}_{\mathrm{CDOM}}(254)$ were significantly correlated with $\mathrm{Chl} a$ _tot, suggesting that CDOM was mainly produced by phytoplankton, but the relative importance of $\mathrm{a}_{\mathrm{CDOM}}$ varied in the different provinces, probably in relation to factors such as the proximity to the coast. The variation in aph*(443) was associated with the chemotaxonomic structure (pigment composition) and photoacclimation processes (changes in the intracellular pigment concentration) in the different phytoplankton communities. Cell size effects could not be appreciated, a finding which can be partly related to the narrow range of Chl $a$ values (lower than $2.4 \mathrm{mg} \mathrm{m}^{-3}$ ) in our data set.

Altogether, although generalizations may be operationally useful, our results indicate that attention to the details of the variability within taxonomic, size or other phytoplankton categorizations is needed in order to improve our understanding of the links between structure and function in the pelagic ecosystem.

\section{ACKNOWLEDGEMENTS}

The cruise TransPEGASO was funded by the Spanish Ministry of Economía and Competitividad through project PEGASO (CTM2012-37615). S.N. was supported with a doctoral fellowship from the National Council of Technological and Scientific Development $(\mathrm{CNPq})$ of Brazil. We are grateful to Manuel Dall'Osto (Chief Scientist), the captain and crew of the BIO Hespérides, the technicians of the Unidad de Tecnología Marina (UTM, CSIC) and the researchers who participated in the cruise for their valuable help. The authors thank Mara Abad for nutrient analyses and Carmen Cabeza for her collaboration with HPLC sample processing.

\section{REFERENCES}

Acevedo-Trejos E., Marañón E., Merico A. 2018. Phytoplankton size diversity and ecosystem function relationships across oceanic regions. Proc. R. Soc. B 285: 20180621

https://doi.org/10.1098/rspb.2018.0621

Aiken J., Pradhan Y., Barlow R., et al. 2009. Phytoplankton pigments and functional types in the Atlantic Ocean: A decadal assessment, 1995-2005. Deep-Sea Res. II 56: 899-917. https://doi.org/10.1016/j.dsr2.2008.09.017

Baker A., Spencer R.G.M. 2004. Characterization of dissolved organic matter from source to sea using fluorescence and absorbance spectroscopy. Sci. Total Environ. 333: 217-232. https://doi.org/10.1016/j.scitotenv.2004.04.013

Barlow R.G., Aiken J., Holligan P.M., et al. 2002. Phytoplankton pigment and absorption characteristics along meridional transects in the Atlantic Ocean. Deep-Sea Res. I 49: 637-660. https://doi.org/10.1016/S0967-0637(01)00081-4

Bidigare R., Ondrusek M., Morrow J.H., et al. 1990. In-vivo absorption properties of algal pigments. Proc. SPIE 1302, Ocean Optics X. https://doi.org/10.1117/12.21451

Bidigare R.R., Buttler F.R., Christensen S.J., et al. 2014. Evaluation of the utility of xanthophyll cycle pigment dynamics for assessing upper ocean mixing processes at Station ALOHA. J. Plankton Res. 36: 1423-1433. https://doi.org/10.1093/plankt/fbu069

Bouman H.A., Platt T., Kraay G.W., et al. 2000. Bio-optical properties of the subtropical North Atlantic. I. Vertical variability. Mar. Ecol. Prog. Ser. 200: 3-18. https://doi.org/10.3354/meps200003

Brewin R.J.W., Sathyendranath S., Lange P.K., et al. 2014. Comparison of two methods to derive the size-structure of natural populations of phytoplankton. Deep-Sea Res. I 85: 72-79. https://doi.org/10.1016/j.dsr.2013.11.007

Bricaud A., Stramski D. 1990. Spectral absorption coefficients of living phytoplankton and nonalgal biogenous matter: A comparison between the Peru upwelling area and the Sargasso Sea. Limnol. Oceanogr. 35: 562-582. https://doi.org/10.4319/1o.1990.35.3.0562

Bricaud A., Babin M., Morel A., et al. 1995. Variability in the chlorophyll-specific absorption coefficients of natural phytoplankton: Analysis and parameterization. J. Geophys. Res. Oceans 100: 13321-13332. https://doi.org/10.1029/95JC00463

Bricaud A., Claustre H., Ras J., et al. 2004. Natural variability of phytoplankton absorption in oceanic waters: influence of the size structure of algal populations. J. Geophys. Res. Oceans 109: C11010. https://doi.org/10.1029/2004JC002419

Bricaud A., Babin M., Claustre H., et al. 2010. Light absorption properties and absorption budget of Southeast Pacific waters. J. Geophys. Res. Oceans 115: C08009. https://doi.org/10.1029/2009JC005517

Brunelle C.B., Larouche P., Gosselin M. 2012. Variability of phytoplankton light absorption in Canadian Arctic seas. J. Geophys. Res. Oceans 117: C00G17. https://doi.org/10.1029/2011JC007345

Cabello A.M., Latasa M., Forn I., et al. 2016. Vertical distribution of major photosynthetic picoeukaryotic groups in stratified marine waters. Environ. Microbiol. 18: 1578-1590. https://doi.org/10.1111/1462-2920.13285

Ciotti A., Lewis M.R., Cullen J.J. 2002. Assessment of the relationships between dominant cell size in natural phytoplankton communities and the spectral shape of the absorption coefficient. Limnol. Oceanogr. 47: 404-417. https://doi.org/10.4319/1o.2002.47.2.0404

Cleveland J.S., Weidemann A.D. 1993. Quantifying absorption by aquatic particles: A multiple scattering correction for glass-fiber filters. Limnol. Oceanogr. 38: 1321-1327. https://doi.org/10.4319/1o.1993.38.6.1321

de Vargas C., Audic S., Henry N., et al. 2015. Eukaryotic plankton diversity in the sunlit ocean. Science 348. 1261605. https://doi.org/10.1126/science.1261605

Dunlap W.P., Dietz J., Cortina J.M. 1997. The Spurious Correlation of Ratios That Have Common Variables: A Monte Carlo Examination of Pearson's Formula. J. Gen. Psychol. 124: 182-193. https://doi.org/10.1080/00221309709595516

Eisner L.B, Twardowski M.S., Cowles T.J., et al. 2003. Resolving phytoplankton photoprotective: photosynthetic carotenoid 
ratios on fine scales using in situ spectral absorption measurements. Limnol. Oceanogr. 48: 632-646. https://doi.org/10.4319/1o.2003.48.2.0632

Falkowski P.G., Laws E.A., Barber R.T., et al. 2003. Phytoplankton and their role in primary, new and export production. In: Fasham M.J.R. (ed.) Ocean Biogeochemistry, Global Change. Global Change-The IGBP Series, Springer, Berlin, Heidelberg, pp. 99-119. https://doi.org/10.1007/978-3-642-55844-3 5

Falster D.S., Warton D.I., Wright I.J. 2006. User's guide to SMATR: Standardised major axis tests and routines, ver 2.0. http://bio.mq.edu.au/research/groups/comparative/SMATR/ SMATR_users_guide.pd

Farrant G.K., Doré H., Cornejo-Castillo F.M, et al. 2016. Delineating ecologically significant taxonomic units from global patterns of marine picocyanobacteria. P. Natl. Acad. Sci. USA 113: E3365-E3374. https://doi.org/10.1073/pnas.1524865113

Ferreira A., Stramski D., Garcia C.A.E., et al. 2013. Variability in light absorption and scattering of phytoplankton in Patagonian waters: Role of community size structure and pigment composition. J. Geophys. Res. Oceans 118: 1-17. https://doi.org/10.1002/jgrc.20082

Ferreira A., Ciotti A.M., Mendes C.R.B., et al. 2017. Phytoplankton light absorption and the package effect in relation to photosynthetic and photoprotective pigments in the northern tip of Antarctic Peninsula. J. Geophys. Res. Oceans 122: 7344-7363. https://doi.org/10.1002/2017JC012964

Ferris J.M., Christian R. 1991. Aquatic primary production in relation to microalgal responses to changing light: a review. Aquat. Sci. 53: $187-217$ https://doi.org/10.1007/BF00877059

Fortier L., Le Fèvre J., Legendre L. 1994. Export of biogenic carbon to fish and to the deep ocean: the role of large planktonic microphages. J. Plankton Res. 16: 809-839. https://doi.org/10.1093/plankt/16.7.809

García V.M.T., García C.A.E., Mata M.M., et al. 2008. Environmental factors controlling the phytoplankton blooms at the $\mathrm{Pa}$ tagonia shelf-break in spring. Deep-Sea Res. I 55: 1150-1166. https://doi.org/10.1016/j.dsr.2008.04.011

Gasol J.M., Giorgio P.A. 2000. Using flow cytometry for counting natural planktonic bacteria and understanding the structure of planktonic bacterial communities. Sci. Mar. 64: 197-224. https://doi.org/10.3989/scimar.2000.64n2197

Gibb S.W., Barlow R.G., Cummings D.G., et al. 2000. Surface phytoplankton pigment distributions in the Atlantic Ocean: an assessment of basin scale variability between $50^{\circ} \mathrm{N}$ and $50^{\circ} \mathrm{S}$. Prog. Oceanogr. 45: 339-368 https://doi.org/10.1016/S0079-6611(00)00007-0

Goodwin L.D., Leech N.L. 2006. Understanding Correlation: Factors That Affect the Size of r. J. Exp. Educ. 74: 249-266. https://doi.org/10.3200/JEXE.74.3.249-266

Goericke R.E., Repeta D.J. 1993. Chlorophylls $a$ and $b$ and divinyl chlorophylls $a$ and $b$ in the open subtropical North Atlantic Ocean. Mar. Ecol. Prog. Ser. 101: 307-313. https://doi.org/10.3354/meps101307

Gonçalves-Araujo R., Rabe B., Peeken I., et al. 2018. High colored dissolved organic matter (CDOM) absorption in surface waters of the central-eastern Arctic Ocean: Implications for biogeochemistry and ocean color algorithm. PLoS ONE 13: 0190838. https://doi.org/10.1371/journal.pone.0190838

Hansen H.P., Koroleff F. 1999. Determination of nutrients. In: Grasshoff K., Kremling K., Ehrhardt M. (eds), Methods of seawater analysis. Whiley-VCH, Weinheim, pp. 159-228. https://doi.org/10.1002/9783527613984.ch10

Herbland A., Le Bouteiller A., Raimbault P. 1985. Size structure of phytoplankton biomass in the equatorial Atlantic Ocean. DeepSea Res. 32: 819-836 https://doi.org/10.1016/0198-0149(85)90118-9

Hirata T., Aiken J., Hardman-Mountford N., et al. 2008. An absorption model to determine phytoplankton size classes from satellite ocean colour. Remote Sens. Environ. 112: 3153-3159. https://doi.org/10.1016/j.rse.2008.03.011

Hirata T., Hardman-Mountford N.J., Brewin R.J.W., et al. 2011. Synoptic relationships between surface chlorophyll $a$ and diagnostic pigments specific to phytoplankton functional types. Biogeosciences 8: 311-327. https://doi.org/10.5194/bg-8-311-2011

Ichinomiya M, Kuwata A. 2015. Seasonal variation in abundance and species composition of the Parmales community in the
Oyashio region, western North Pacific. Aquat. Microb. Ecol. 75: 207-223

https://doi.org/10.3354/ame01756

Ichinomiya M., Yoshikawa S., Kamiya M., et al. 2010. Isolation and characterization of Parmales Heterokonta/Heterokontophyta/ Stramenopiles) from the Oyashio region, western north Pacific. J. Phycol. 47: 144-151. https://doi.org/10.1111/j.1529-8817.2010.00926.x

Ichinomiya M., Santo A.L., Gourvil P., et al. 2016. Diversity and oceanic distribution of the Parmales (Bolidophyceae), a picoplanktonic group closely related to diatoms. ISME J. 10: 2419-2434.

https://doi.org/10.1038/ismej.2016.38

Jewson D., Kuwata A., Cros L., et al. 2016. Morphological adaptations to small size in the marine diatom Minidiscus comicus. Sci. Mar. 80S1: 89-96. https://doi.org/10.3989/scimar.04331.06C

Johnson Z.I., Zinser E.R., Coe A., et al. 2006. Niche partitioning among Prochlorococcus ecotypes along ocean-scale environmental gradients. Science 311: 1737-1740. https://doi.org/10.1126/science.1118052

Kaczmarska I, Lovejoy C., Potvin M., et al. 2009. Morphological and molecular characteristics of selected species of Minidiscus (Bacillariophyta, Thalassiosiraceae), Eur. J. Phycol. 44: 461-475. https://doi.org/10.1080/09670260902855873

Kheireddine M., Ouhssain M., Organelli E., et al. 2018. Light absorption by suspended particles in the Red Sea: Effect of phytoplankton community size structure and pigment composition. J. Geophys. Res. Oceans 123: 902-921. https://doi.org/10.1002/2017JC013279

Kiørboe T. 1993. Turbulence, phytoplankton cell size, and the structure of pelagic food webs. Adv. Mar. Biol. 29: 1-72. https://doi.org/10.1016/S0065-2881(08)60129-7

Kishino M., Takahashi M., Okami N., et al. 1985. Estimation of the spectral absorption coefficients of phytoplankton in the sea. Bull. Mar. Sci. 37: 634-642.

Kitidis V., Stubbins A., Günther U., et al. 2006. Variability of chromophoric organic matter in surface waters of the Atlantic Ocean. Deep-Sea Res. II 53. 1666-1684. https://doi.org/10.1016/j.dsr2.2006.05.009

Klaas C., Archer D.E. 2002. Association of sinking organic matter with various types of mineral ballast in the deep sea: Implications for the rain ratio. Global Biogeochem. Cycles 16: 1116. https://doi.org/10.1029/2001GB001765

Latasa M. 2007 Improving estimations of phytoplankton class abundances using CHEMTAX. Mar. Ecol. Prog. Ser. 329: 13-21. https://doi.org/10.3354/meps329013

Latasa M. 2014. A simple method to increase sensitivity for RPHPLC phytoplankton pigment analysis. Limnol. Oceanogr. Methods 12: 45-63. https://doi.org/10.4319/lom.2014.12.46

Latasa M., Scharek R. Vidal M. et al. 2010. Preferences of phytoplankton groups for waters of different trophic status in the northwestern Mediterranean Sea. Mar. Ecol. Prog. Ser. 407: 27-42. https://doi.org/10.3354/meps08559

Le Queré C., Harrison S.P., Prentice I.C., et al. 2005. Ecosystem dynamics based on plankton functional types for global ocean biogeochemistry models. Glob. Change Biol. 11: 2016-2040. https://doi.org/10.1111/j.1365-2486.2005.1004.x

Leblanc K., Quéguiner B., Diaz F., et al. 2018. Nanoplanktonic diatoms are globally overlooked but play a role in spring blooms and carbon export. Nat. Commun. 9: 953. https://doi.org/10.1038/s41467-018-03376-9

Légendre P., Légendre L. 1998. Numerical ecology. Elsevier Science BV. Amsterdam, 853 pp.

Litchman E., Klausmeier C.A. 2008. Trait-Based Community Ecology of phytoplankton. Annu. Rev. Ecol. Evol. Syst. 39: 615-639. https://doi.org/10.1146/annurev ecolsys.39.110707.173549

Longhurst A.R. 2007. Ecological geography of the sea. Academic Press, Burlington, MA. 542 pp. https://doi.org/10.1016/B978-012455521-1/50002-4

Macías D., Martin A.P., García Lafuente J., et al. 2007. Mixing and biogeochemical effects induced by tides at on the AtlanticMediterranean flow in the Strait of Gibraltar. Prog. Oceanogr. 74: 252-272.

https://doi.org/10.1016/j.pocean.2007.04.006

Mackey M.D., Higgins H.W., Wright S.W. 1996. CHEMTAX - a program for estimating class abundances from chemical mark- 
ers: application to HPLC measurements of phytoplankton. Mar. Ecol. Prog. Ser. 144: 265-283.

https://doi.org/10.3354/meps 144265

Marañón E, Holligan P, Barciela R, et al. 2001. Patterns of phytoplankton size structure and productivity in contrasting openocean environments. Mar. Ecol. Prog. Ser. 216: 43-56. https://doi.org/10.3354/meps216043

Margalef R. 1978. Life-forms of phytoplankton as survival alternatives in an unstable environment. Oceanol. Acta 1: 493-509.

Massana R. 2011. Eukaryotic picoplankton in surface oceans. Annu. Rev. Microbiol. 65: 91-110. https://doi.org/10.1146/annurev-micro-090110-102903

Menna M., Faye S., Poulain P-M., et al. 2016. Upwelling features off the coast of north-western Africa in 2009-2013. Bol. Geofis. Teor. Appl. 57: 71-86.

Mitchell G., Kiefer D.A. 1988. Chlorophyll $a$ specific absorption and fluorescence excitation spectra for light- limited phytoplankton. Deep-Sea Res. 35: 639-663. https://doi.org/10.1016/0198-0149(88)90024-6

Mitchell G., Carder K., Cleveland J., et al. 2000. Determination of spectral absorption coefficients of particles, dissolved material and phytoplankton for discrete water samples. In: Fargion G.S. Mueller J.L. (eds), Ocean Optics Protocols for Satellite Ocean Colour Sensor Validation, Revision 2. NASA Tech. Memo. 209966, NASA Goddard Space Flight Center. Greenbelt. Maryland. pp. 125-153.

Morel A., Gentili B., Claustre H., et al. 2007. Optical properties of the "clearest" natural waters. Limnol. Oceanogr. 52: 217-229. https://doi.org/10.4319/1o.2007.52.1.0217

Mousseau L., Klein B., Legendre L., et al. 2001. Assessing the trophic pathways that dominate planktonic food webs: an approach based on simple ecological ratios. J. Plankton Res. 23: 765-777. https://doi.org/10.1093/plankt/23.8.765

Murphy L.S., Haugen E.M. 1985. The distribution and abundance of phototrophic ultraplankton in the North Atlantic. Limnol. Oceanogr. 30: 47-58. https://doi.org/10.4319/1o.1985.30.1.0047

Nair A., Sathyendranath S., Platt T., et al. 2008. Remote sensing of phytoplankton functional types. Remote Sens. Environ. 112: 3366-3375. https://doi.org/10.1016/j.rse.2008.01.021

Nelson N.B., Siegel D.A., Michaels A.F. 1998. Seasonal dynamics of colored dissolved material in the Sargasso Sea. Deep-Sea Res. I 45: 931-957. https://doi.org/10.1016/S0967-0637(97)00106-4

Partensky F. Hess W.R., Vaulot D. 1999. Prochlorococcus, a marine photosynthetic prokaryote of global significance. Microbiol. Mol. Biol. Rev. 63: 106-127.

Pérez G.L., Galí M., Royer S-J., et al. 2016. Bio-optical characterization of offshore NW Mediterranean waters: CDOM contribution to the absorption budget and diffuse attenuation of downwelling irradiance. Deep-Sea Res. I 114: 111-127. https://doi.org/10.1016/j.dsr.2016.05.011

Pope R.M., Fry E.S. 1997. Absorption spectrum $(380-700 \mathrm{~nm})$ of pure water. II. Integrating cavity measurements. Appl. Opt. 36 8710-8723 https://doi.org/10.1364/AO.36.008710

Romera-Castillo C., Alvarez-Salgado X.A., Galí M., et al. 2013. Combined effect of light exposure and microbial activity on distinct dissolved organic matter pools. A seasonal field study in an oligotrophic coastal system (Blanes Bay, NW Mediterranean). Mar. Chem. 148: 44-51. https://doi.org/10.1016/j.marchem.2012.10.004

Roy S., Llewellyn C.A., Egeland E.S., et al. 2011. Phytoplankton pigments: characterization, chemotaxonomy, and applications in oceanography. Cambridge University, Cambridge, UK. 845 pp.

Simó R. 2001. Production of atmospheric sulfur by oceanic plankton: Biogeochemical, ecological and evolutionary links. Trends Ecol. Evol. 16: 287-294. https://doi.org/10.1016/S0169-5347(01)02152-8

Sournia A., Chrétiennot-Dinet M.J., Ricard M. 1991. Marine phytoplankton: how many species in the world ocean? J. Plankton Res. 13: 1093-1099. https://doi.org/10.1093/plankt/13.5.1093

Souza M.S., Mendes C.R.B, García V.M.T., et al. 2012. Phytoplankton community during a coccolithophorid bloom in the Patagonian Shelf: microscopic and high-performance liquid chromatography pigment analyses. J. Mar. Biol. Ass. UK 92: $13-27$

https://doi.org/10.1017/S0025315411000439
Taylor B.B., Torrecila E., Bernhardt A., et al. 2011. Bio-optical provinces in the eastern Atlantic Ocean and their biogeographical relevance. Biogeosciences 8: 3609-3629. https://doi.org/10.5194/bg-8-3609-2011

Thingstad T.F., Hagström A., Rassoulzadegan F. 1997. Accumulation of degradable DOC in surface waters: Is it caused by a malfunctioning microbial loop? Limnol. Oceanogr. 42: 398-404. https://doi.org/10.4319/1o.1997.42.2.0398

Tintoré J., Gomis D., Alonso S., et al. 1991. Mesoscale dynamics and vertical motion in the Alboran Sea. J. Phys. Oceanogr. 21: 811-823.

https://doi.org/10.1175/1520-0485(1991)021<0811:MDAVMI $>2.0 . \mathrm{CO} ; 2$

Uitz J., Claustre H., Morel A., et al. 2006. Vertical distribution of phytoplankton communities in Open Ocean: An assessment based on surface chlorophyll. J. Geophys. Res. Oceans 111: $1-23$. https://doi.org/10.1029/2005JC003207

Utermöhl H. 1958. Zur Vervollkommung der quantitativen Phytoplankton-Methodik. Mitt. Internat. Verein. Theor. Angew. Limnol. 9: 1-38. https://doi.org/10.1080/05384680.1958.11904091

Vaulot D., Eikrem W., Viprey M., et al. 2008. The diversity of small eukaryotic phytoplankton $(\leq 3 \mu \mathrm{m})$ in marine ecosystems. FEMS Microbiol. Rev. 32: 795-820. https://doi.org/10.1111/j.1574-6976.2008.00121.x

Vega-Moreno D., Marrero J.P, Morales J., et al. 2012. Phytoplankton functional community structure in Argentinian continental shelf determined by HPLC pigment signatures. Estuar. Coast. Shelf Sci. 100: 72-81. https://doi.org/10.1016/j.ecss.2012.01.007

Vidussi F., Claustre H., Manca B.B., et al. 2001. Phytoplankton pigment distribution in relation to upper thermocline circulation in the eastern Mediterranean Sea during winter. J. Geophys. Res. Oceans 106: 19939-19956. https://doi.org/10.1029/1999JC000308

Wang S.Q., Ishizaka J., Yamaguchi H., et al. 2014. Influence of the Changjiang River on the light absorption properties of phytoplankton from the East ChinaSea. Biogeosciences 11: 1759-1773. https://doi.org/10.5194/bg-11-1759-2014

Warton D.I., Wright I.J., Falster D.S., et al. 2006. Bivariate linefitting methods for allometry. Biol. Rev. 81: 259-291. https://doi.org/10.1017/S1464793106007007

Weishaar J.L., Aiken G.R., Bergamaschi B.A., et al. 2003. Evaluation of specific ultraviolet absorbance as an indicator of the chemical composition and reactivity of dissolved organic carbon. Environ. Sci. Technol. 37: 4702-4708. https://doi.org/10.1021/es030360x

Xing X., Claustre H., Wang H., et al. 2014. Seasonal dynamics in colored dissolved organic matter in the Mediterranean Sea: patterns and drivers. Deep-Sea Res. I 83:93-101. https://doi.org/10.1016/j.dsr.2013.09.008

Yentsch C., Menzel D.W. 1963. A method for the determination of phytoplankton chlorophyll and phaeophytin by fluorescence. Deep-Sea Res. 10: 221-231. https://doi.org/10.1016/0011-7471(63)90358-9

Zamanillo M., Ortega-Retuerta E., Nunes S., et al. 2019. Main drivers of transparent exopolymer particle distribution across the surface Atlantic Ocean. Biogeosciences 16: 733-749. https://doi.org/10.5194/bg-16-733-2019

Zeng C., Rosengarda S.Z., Burta W., et al. 2018. Optically-derived estimates of phytoplankton size class and taxonomic group biomass in the Eastern Subarctic Pacific Ocean. Deep-Sea Res. I 136: $107-118$. https://doi.org/10.1016/j.dsr.2018.04.001

\section{SUPPLEMENTARY MATERIAL}

The following supplementary material is available through the online version of this article and at the following link:

http://scimar.icm.csic.es/scimar/supplm/sm04866esm.pdf

Table S1. - Province allocation, position and sampling date and time of the TransPEGASO stations.

Table S2. - Pigment ratios used for the runs of the different CHEMTAX clusters (cluster 1 includes MEFI and SWAS; cluster 2, the other provinces). The numbers indicate the amount of pigment per unit of Chl $a$. See Table 1 for pigment name abbreviations.

Table S3. - Range (minimum: Min and maximum: Max), mean and 
standard deviation (SD) of pigment concentrations $\left(\mathrm{ng} \mathrm{L}^{-1}\right)$ and pigment ratios in the $\geq 3 \mu \mathrm{M}$ size fraction of surface seawater for the seven study provinces. LHC, light-harvesting pigments (19'But + 19'Hex + Fuco + Per). For province names, see the explanation in Figure 1.

Table S4. - Range (minimum: Min and maximum: Max), mean and standard deviation (SD) of pigment concentrations $\left(\mathrm{ng} \mathrm{L}^{-1}\right)$ and pigment ratios in the $<3 \mu \mathrm{M}$ size fraction of surface seawater for the seven study provinces. LHC, light-harvesting pigments $\left(19^{\prime}\right.$ But $+19^{\prime} \mathrm{Hex}+$ Fuco + Per). For province names, see the explanation of Figure 1

Table S5 - Abundance, in cells $\mathrm{L}^{-1}$ of selected frequent phytoplankton taxa (the 10 most frequent in the case of dinoflagellates, diatoms and coccolithophores) and total values for major groups.

Fig. S1. - A, relationships between regression of $\mathrm{Chl} a \mathrm{Fl}$ and Chl $a$ tot $),$ Chl $a \_\mathrm{Fl}=1.76 * \mathrm{Chl} a$ tot $+0.17, \mathrm{n}=41, \overline{\mathrm{r}}^{2}=0.96$, $\mathrm{p}<0.0001$ (one Chl $a_{\text {_t tot }}$ outlier for station 41 was excluded); $B$, between the sum of the $<3$ (f_pico $<3$ ) and the $\geq 3$ (f_n+m 1 ) Chl $a$ filtration fractions (Chl $a$ pico $<3+\mathrm{n}+\mathrm{m} \geq 3$ ) and $\mathrm{Chl} a$ tot, Chl a_pico $<3+\mathrm{n}+\mathrm{m} \geq 3=0.85+\mathrm{Chl} a_{-}$tot $+0.005 ; \mathrm{n}=41$, $\mathrm{r}^{2}=0.95, \mathrm{p}<0.0001$; the same outlier was also excluded); $\mathrm{C}$, between f pico $<3$ and $\log (\mathrm{Chl} a$ tot); D, between PC2 and PC1. The numbers within the graph indicate the provinces (see the explanation of Table S1 for abbreviations). 1, MEDI; 2, NASTE; 3, CNRY; 4, NATR; 5, WTRA; 6, SATL; 7, SWAS.

Fig. S2. - Average HPLC-determined concentration of the 11 globally most abundant pigments plus the biomarkers alloxanthin, neoxanthin, peridinin, prasinoxanthin and violaxanthin in the seven provinces for whole water (A), the $\mathrm{f} n+\mathrm{n} \geq 3$ fraction (B) and the $\mathrm{f} \_$pico $<3$ fraction $(\mathrm{C})$. Province name abbreviations as in Table $\mathrm{S} 1$. Pigment abbreviations as in Table 1 .

Fig. S3. - A, relationship between Ddx/LSC and solar radiation, $y$ $=9.72 \mathrm{e}-5 * x+0.162, \mathrm{n}=40, \mathrm{r}^{2}=0.14, \mathrm{p}<0.05 ; \mathrm{B}$, between SDP and Chl $a$ _tot, SDP $=0.96 * \mathrm{Chl} a \_$tot $-0.01, \mathrm{n}=41, \mathrm{r}^{2}=0.88$, $\mathrm{p}<0.0001$.
Fig. S4. - Scanning electron micrographs of Triparma laevis (Parmales) (A, B) and Minidiscus sp. (Bacillariophyceae) (C, D).

Fig. S5. - A to D, log-log standard major axis regressions of the picoplankton and nano+microphytoplankton contributions to total Chl $a$ (in $\mathrm{mg} \mathrm{m}^{-3}$ ) estimated by the methods of Vidussi et al. (2001)-Uitz et al. (2006) (Chl $a \_p i c o V U$ and $\mathrm{Chl} a \_n+m V U$, respectively) and Hirata et al. (2011) (Chl $a_{-}$picoHI and $\mathrm{Chl} a_{-}$ $\mathrm{n}+\mathrm{mHI}$, respectively), with the $\mathrm{Chl} a \_$pico $<\overline{3}$ and $\mathrm{Chl} a \mathrm{n}+\mathrm{m} \geq \overline{3}$ derived from the filtrations. The equations are (A) $\log (\mathrm{Chl}$ a_picoVU $)=0.90 * \log ($ Chl a_pico $<3)-0.22, \mathrm{n}=41, \mathrm{r}^{2}=0.69$, $\mathrm{p}<0.0001 ; \mathrm{B}, \log \left(\mathrm{Chl} a \_\right.$picoHI $)=0.67 * \log \left(\mathrm{Chl} a \_\right.$pico $\left.<3\right)$ $-0.49, \mathrm{n}=41, \mathrm{r}^{2}=0.95, \mathrm{p}<0.0001 ; \mathrm{C}, \log (\mathrm{Chl} a \mathrm{n}+\mathrm{mVU})=$ $0.89 * \log \left(\mathrm{Chl} a \_\mathrm{n}+\mathrm{m} \geq 3\right)+0.27, \mathrm{n}=41, \mathrm{r}^{2}=0.86, \mathrm{p}<0.0001 ; \mathrm{D}$, $\log \left(\mathrm{Chl} a \_\mathrm{n}+\mathrm{mHI}\right)=0.94 * \log \left(\mathrm{Chl} a \_\mathrm{n}+\mathrm{m} \geq 3\right)+0.40, \mathrm{n}=41$, $\mathrm{r}^{2}=0.86, \mathrm{p}<0.0001$. In $\mathrm{A}, \mathrm{C}$ and $\mathrm{D}$ the slopes were not statistically different from 1

Fig. S6. - A, regression of the logarithm of the size index (SI) on $\log (\mathrm{Chl} a$ tot $)[\log (\mathrm{Si})=0.28 * \log (\mathrm{Chl} a$ tot $)+1.24, \mathrm{n}=41$, $\left.\mathrm{r}^{2}=0.38, \mathrm{p}<0.0001\right]$; and $\mathrm{B}$, of the logarithm of the size index (SI) on $\mathrm{f}$ _pico $<3\left[\log (\mathrm{Si})=-0.65 * \mathrm{f}\right.$ _pico $<3+1.50, \mathrm{n}=41, \mathrm{r}^{2}=0.14$, $\mathrm{p}<0.05]$. The numbers within the graph indicate the provinces (see the explanation of Table S1 for abbreviations). 1, MEDI; 2 , NAST-E; 3, CNRY; 4, NATR; 5, WTRA; 6, SATL; 7, SWAS.

Fig. S7. - A, relationships between $\mathrm{Qa}^{*}(443)$ and $\log (\mathrm{Si}) ; \mathrm{B}$, between $\mathrm{Qa}^{*}(443)$ and the proportion of Chl $a$ in the $<3 \mu \mathrm{m}$ fraction of the filtrations ( $\mathrm{f}$ pico<3); C, between $\mathrm{a}_{\mathrm{p}} *(443)$ and $\log (\mathrm{Si})$; and $\mathrm{D}$, between $\mathrm{a}_{\mathrm{ph}} *(443)$ and $\mathrm{f} \_$pico $<3$. The numbers within the graph indicate the provinces (see the explanation of Table S1 for abbreviations). 1, MEDI; 2, NAST-E; 3, CNRY; 4, NATR; 5, WTRA; 6, SATL; 7, SWAS.

Fig. S8. - Geographic distribution of the ratio $\mathrm{a}_{\mathrm{CDOM}}(254) / \mathrm{Chl} a_{-}$tot (units are $\mathrm{m}^{-1}$ and $\mathrm{mg} \mathrm{m}^{-3}$, respectively). The lines indicate province limits, as in Figure 1. 
Scientia Marina 83(2)

June 2019, S1-S13, Barcelona (Spain)

ISSN-L: 0214-8358

\section{Size fractionation, chemotaxonomic groups and bio-optical properties of phytoplankton along a transect from the Mediterranean Sea to the Atlantic Ocean}

Sdena Nunes, Gonzalo Luís Perez, Mikel Latasa, Marina Zamanillo, Maximino Delgado, Eva Ortega-Retuerta, Celia Marrasé, Rafel Simó, Marta Estrada

Supplementary material 
Table S1. - Province allocation, position and sampling date and time of the TransPEGASO stations.

\begin{tabular}{|c|c|c|c|c|c|c|}
\hline $\begin{array}{l}\text { Biogeographical } \\
\text { provinces }\end{array}$ & Station number & Date & Longitude $\left[{ }^{\circ} \mathrm{W}\right]$ & Latitude $\left[{ }^{\circ} \mathrm{N}\right]$ & Local time & GMT time \\
\hline MEDI & 1 & $10 / 21 / 2014$ & -5.21 & 36.02 & 9:00 AM & 8:00 AM \\
\hline NAST & 2 & $10 / 21 / 2014$ & -6.51 & 35.30 & 4:00 PM & 3:00 PM \\
\hline NAST & 3 & $10 / 22 / 2014$ & -9.23 & 33.23 & 9:00 AM & 8:00 AM \\
\hline NAST & 4 & $10 / 23 / 2014$ & -12.40 & 30.32 & 9:00 AM & 8:00 AM \\
\hline NAST & 5 & $10 / 23 / 2014$ & -13.28 & 29.49 & 4:00 PM & 3:00 PM \\
\hline NAST & 6 & $10 / 24 / 2014$ & -15.17 & 27.38 & 4:00 PM & 4:00 PM \\
\hline CNRY & 7 & $10 / 25 / 2014$ & -16.52 & 24.22 & 9:00 AM & 9:00 AM \\
\hline CNRY & 8 & $10 / 25 / 2014$ & -17.30 & 23.30 & 4:00 PM & 4:00 PM \\
\hline CNRY & 9 & $10 / 26 / 2014$ & -19.02 & 20.33 & 9:00 AM & 8:00 AM \\
\hline CNRY & 10 & $10 / 26 / 2014$ & -19.39 & 19.20 & 4:00 PM & 3:00 PM \\
\hline NATR & 11 & $10 / 27 / 2014$ & -21.23 & 16.23 & 9:00 AM & $8: 00 \mathrm{AM}$ \\
\hline NATR & 12 & $10 / 27 / 2014$ & -21.44 & 15.11 & 4:00 PM & 3:00 PM \\
\hline NATR & 13 & $10 / 28 / 2014$ & -23.18 & 12.01 & 9:00 AM & $8: 00$ AM \\
\hline WTRA & 14 & $10 / 28 / 2014$ & -23.57 & 10.43 & 4:00 PM & 3:00 PM \\
\hline WTRA & 15 & $10 / 29 / 2014$ & -25.34 & 7.24 & 9:00 AM & 8:00 AM \\
\hline WTRA & 16 & $10 / 29 / 2014$ & -26.12 & 6.05 & 4:00 PM & 3:00 PM \\
\hline WTRA & 17 & $10 / 30 / 2014$ & -27.40 & 3.03 & 9:00 AM & 9:00 AM \\
\hline WTRA & 18 & $10 / 30 / 2014$ & -28.16 & -1.48 & 4:00 PM & 4:00 PM \\
\hline WTRA & 19 & $10 / 31 / 2014$ & -29.47 & -1.21 & 9:00 AM & 9:00 AM \\
\hline WTRA & 20 & $10 / 31 / 2014$ & -30.28 & -2.45 & 4:00 PM & 4:00 PM \\
\hline SATL & 21 & $11 / 1 / 14$ & -32.02 & -6.02 & 9:00 AM & 9:00 AM \\
\hline SATL & 22 & $11 / 2 / 14$ & -31.56 & -10.06 & 9:00 AM & 9:00 AM \\
\hline SATL & 23 & $11 / 2 / 14$ & -32.23 & -10.39 & 4:00 PM & 5:00 PM \\
\hline SATL & 24 & $11 / 3 / 14$ & -33.54 & -14.57 & 9:00 AM & $10: 00 \mathrm{AM}$ \\
\hline SATL & 25 & $11 / 3 / 14$ & -34.20 & -14.57 & 4:00 PM & 5:00 PM \\
\hline SATL & 26 & $11 / 4 / 14$ & -35.32 & -15.60 & 9:00 AM & 10:00 AM \\
\hline SATL & 27 & $11 / 4 / 14$ & -36.05 & -18.51 & 4:00 PM & 5:00 PM \\
\hline SATL & 28 & $11 / 5 / 14$ & -37.12 & -20.12 & 9:00 AM & 10:00 AM \\
\hline SATL & 29 & $11 / 5 / 14$ & -38.22 & -23.41 & 4:00 PM & 5:00 PM \\
\hline SATL & 30 & $11 / 6 / 14$ & -41.26 & -24.43 & 9:00 AM & 10:00 AM \\
\hline SATL & 31 & $11 / 6 / 14$ & -42.29 & -26.51 & 4:00 PM & 5:00 PM \\
\hline SATL & 32 & $11 / 7 / 14$ & -45.15 & -29.30 & 9:00 AM & 11:00 AM \\
\hline SWAS & 33 & $11 / 17 / 2014$ & -56.27 & -38.45 & 9:00 AM & 12:00 PM \\
\hline SWAS & 34 & $11 / 17 / 2014$ & -57.19 & -39.56 & 4:00 PM & 7:00 PM \\
\hline SWAS & 35 & $11 / 18 / 2014$ & -59.27 & -42.35 & 9:00 AM & 12:00 PM \\
\hline SWAS & 36 & $11 / 18 / 2014$ & -60.22 & -43.43 & 4:00 PM & 7:00 PM \\
\hline SWAS & 37 & $11 / 19 / 2014$ & -62.36 & -46.26 & 9:00 AM & 12:00 PM \\
\hline SWAS & 38 & $11 / 19 / 2014$ & -63.25 & -47.19 & 4:00 PM & 7:00 PM \\
\hline SWAS & 39 & $11 / 20 / 2014$ & -64.54 & -48.59 & 9:00 AM & 12:00 PM \\
\hline SWAS & 40 & $11 / 20 / 2014$ & -65.33 & -49.42 & 4:00 PM & 7:00 PM \\
\hline SWAS & 41 & $11 / 21 / 2014$ & -67.05 & -51.20 & 8:00 AM & 11:00 AM \\
\hline SWAS & 42 & $11 / 21 / 2014$ & -67.41 & -51.52 & 3:00 PM & 6:00 PM \\
\hline
\end{tabular}


Table S2. - Pigment ratios used for the runs of the different CHEMTAX clusters (cluster 1 includes MEFI and SWAS; cluster 2, the other provinces). The numbers indicate the amount of pigment per unit of Chl $a$. See Table 1 for pigment name abbreviations.

\begin{tabular}{|c|c|c|c|c|c|c|c|c|c|c|c|c|c|}
\hline & Chl $c 2$ & Per & 19’But & Fuco & $\mathrm{Neo}$ & Pras & Viol & $19{ }^{\prime} \mathrm{Hex}$ & Allo & Zea & Chl $b$ & DV-Chl $a$ & $\begin{array}{c}\text { Chl } c 2-\mathrm{MGDG} \\
{[14 / 14]}\end{array}$ \\
\hline \multicolumn{14}{|l|}{$\begin{array}{l}\text { PRASINOPHYTES } \\
\text { pico<3 }\end{array}$} \\
\hline Cluster 1 & - & - & - & - & 0.11 & 0.28 & 0.07 & - & - & 0.13 & 0.74 & - & - \\
\hline Cluster2 & - & - & - & - & 0.07 & 0.20 & 0.10 & - & - & 0.10 & 0.68 & - & - \\
\hline \multicolumn{14}{|l|}{$\mathrm{n}+\mathrm{m}>3$} \\
\hline Cluster 1 & - & - & - & - & 0.13 & 0.21 & 0.08 & - & - & 0.13 & 0.80 & - & - \\
\hline Cluster2 & - & - & - & - & 0.05 & 0.07 & 0.03 & - & - & 0.08 & 0.20 & - & - \\
\hline $\begin{array}{l}\text { Total } \\
\text { Cluster } 1\end{array}$ & - & - & - & - & 0.12 & 0.27 & 0.08 & - & - & 0.13 & 0.69 & - & - \\
\hline & - & - & - & - & 0.08 & 0.19 & 0.07 & - & - & 0.11 & 1.46 & - & - \\
\hline \multicolumn{14}{|l|}{$\begin{array}{l}\text { CHLOROPHYTES } \\
\text { pico<3 }\end{array}$} \\
\hline Cluster 1 & - & - & - & - & 0.24 & 0.00 & 0.07 & - & - & 0.13 & 0.31 & - & - \\
\hline \multirow{2}{*}{\multicolumn{14}{|c|}{$\mathrm{n}+\mathrm{m}>3$}} \\
\hline & & & & & & & & & & & & & \\
\hline Cluster 1 & - & - & - & - & 0.19 & 0.00 & 0.08 & - & - & 0.13 & 0.31 & - & - \\
\hline \multirow{2}{*}{\multicolumn{14}{|c|}{ Total }} \\
\hline & & & & & & & & & & & & & \\
\hline Cluster2 & - & - & - & - & 0.23 & 0.00 & 0.08 & - & - & 0.13 & 0.33 & - & - \\
\hline DINOFLAGELLATES & & & & & & & & & & & & & \\
\hline $\begin{array}{l}\text { pico }<3 \\
\text { Cluster } 1\end{array}$ & 0.13 & 0.61 & - & - & - & & & - & - & - & & & \\
\hline Cluster2 & 0.13 & 0.66 & - & - & - & - & - & - & - & - & - & - & - \\
\hline $\mathrm{n}+\mathrm{m}>3$ & & & & & & & & & & & & & \\
\hline Cluster 1 & 0.12 & 0.63 & - & - & - & - & - & - & - & - & - & - & - \\
\hline Cluster2 & 0.06 & 0.37 & - & - & - & - & - & - & - & - & - & - & - \\
\hline Total & & & & & & & & & & & & & \\
\hline Cluster 1 & 0.13 & 0.67 & - & - & - & - & - & - & - & - & - & - & - \\
\hline Cluster2 & 0.12 & 0.56 & - & - & - & - & - & - & - & - & - & - & - \\
\hline $\begin{array}{l}\text { CRYPTOPHYTES } \\
\text { pico<3 }\end{array}$ & & & & & & & & & & & & & \\
\hline Cluster 1 & 0.18 & - & - & - & - & - & - & - & 0.54 & - & - & - & - \\
\hline Cluster2 & 0.18 & - & - & - & - & - & - & - & 0.56 & - & - & - & - \\
\hline $\mathrm{n}+\mathrm{m}>3$ & & & & & & & & & & & & & \\
\hline Cluster 1 & 0.18 & - & - & - & - & - & - & - & 0.56 & - & - & - & - \\
\hline $\begin{array}{l}\text { Cluster2 } \\
\text { Total }\end{array}$ & 0.09 & - & - & - & - & - & - & - & 0.41 & - & - & - & - \\
\hline $\begin{array}{l}\text { Total } \\
\text { Cluster } 1\end{array}$ & 018 & & & & & & & & & & & & \\
\hline Cluster 1 & 0.18 & - & - & - & - & - & - & - & 0.61 & - & - & - & - \\
\hline $\begin{array}{l}\text { Cluster2 } \\
\text { HAPOPHYTES }\end{array}$ & 0.18 & - & - & - & - & - & - & - & 0.61 & - & - & - & - \\
\hline $\begin{array}{l}\text { HAPTOPHYTES } \\
n+m>3\end{array}$ & & & & & & & & & & & & & \\
\hline Cluster 1 & 0.14 & - & 0.24 & 0.14 & - & - & - & 0.66 & - & - & - & - & 0.13 \\
\hline Cluster2 & 0.08 & - & 0.19 & 0.12 & - & - & - & 0.92 & - & - & - & - & 0.05 \\
\hline P_n+m & & & & & & & & & & & & & \\
\hline Cluster 1 & 0.14 & - & 0.10 & 0.14 & - & - & - & 0.61 & - & - & - & - & 0.14 \\
\hline Cluster2 & 0.08 & - & 0.09 & 0.08 & - & - & - & 0.04 & - & - & - & - & 0.04 \\
\hline Total & & & & & & & & & & & & & \\
\hline Cluster 1 & 0.13 & - & 0.17 & 0.13 & - & - & - & 0.63 & - & - & - & - & 0.11 \\
\hline $\begin{array}{l}\text { Cluster2 } \\
\text { PELAGOPHYTES }\end{array}$ & 0.15 & - & 0.11 & 0.13 & - & - & - & 0.74 & - & - & - & - & 0.06 \\
\hline $\begin{array}{l}\text { PELAGOPHYTES } \\
\text { pico<3 }\end{array}$ & & & & & & & & & & & & & \\
\hline Cluster 1 & 0.51 & - & 0.65 & 0.26 & - & - & - & - & - & - & - & - & - \\
\hline Cluster2 & 0.45 & - & 0.61 & 0.27 & - & - & - & - & - & - & - & - & - \\
\hline $\mathrm{n}+\mathrm{m}>3$ & & & & & & & & & & & & & \\
\hline Cluster 1 & 0.51 & - & 0.65 & 0.27 & - & - & - & - & - & - & - & - & - \\
\hline Cluster2 & 0.17 & - & 0.30 & 0.13 & - & - & - & - & - & - & - & - & - \\
\hline Total & & & & & & & & & & & & & \\
\hline Cluster 1 & 0.42 & - & 0.65 & 0.27 & - & - & - & - & - & - & - & - & - \\
\hline Cluster2 & 0.38 & - & 0.68 & 0.25 & - & - & - & - & - & - & - & - & - \\
\hline $\begin{array}{l}\text { DIATOMS } \\
\text { pico }<3\end{array}$ & & & & & & & & & & & & & \\
\hline Cluster 1 & 0.26 & - & 0.00 & 0.70 & - & - & - & - & - & - & - & - & - \\
\hline Cluster2 & 0.12 & - & 0.00 & 0.46 & - & - & - & - & - & - & - & - & - \\
\hline $\mathrm{n}+\mathrm{m}>3$ & & & & & & & & & & & & & \\
\hline Cluster 1 & 0.12 & - & 0.00 & 0.53 & - & - & - & - & - & - & - & - & - \\
\hline Cluster2 & 0.06 & - & 0.00 & 0.34 & - & - & - & - & - & - & - & - & - \\
\hline Total & & & & & & & & & & & & & \\
\hline Cluster 1 & 0.17 & - & 0.00 & 0.70 & - & - & - & - & - & - & - & - & - \\
\hline Cluster2 & 0.12 & - & 0.00 & 0.41 & - & - & - & - & - & - & - & - & - \\
\hline $\begin{array}{l}\text { Synecoccoccus } \\
\text { pico }<3\end{array}$ & & & & & & & & & & & & & \\
\hline Cluster 1 & - & - & - & - & - & - & - & - & - & 1.05 & - & - & - \\
\hline Cluster2 & - & - & - & - & - & - & - & - & - & 0.64 & - & - & - \\
\hline Total & & & & & & & & & & & & & \\
\hline Cluster 1 & - & - & - & - & - & - & - & - & - & 0.74 & - & - & - \\
\hline Cluster2 & - & - & - & - & - & - & - & - & - & 0.66 & - & - & - \\
\hline $\begin{array}{l}\text { Phroclorococcus } \\
\text { pico }<3\end{array}$ & & & & & & & & & & & & & \\
\hline $\begin{array}{l}\text { pico<3 } \\
\text { Cluster } 1\end{array}$ & - & - & - & - & - & - & - & - & - & 0.71 & 0.20 & 1.00 & - \\
\hline Total & & & & & & & & & & & & & \\
\hline Cluster 1 & - & - & - & - & - & - & - & - & - & 0.80 & 0.28 & 1.00 & - \\
\hline
\end{tabular}




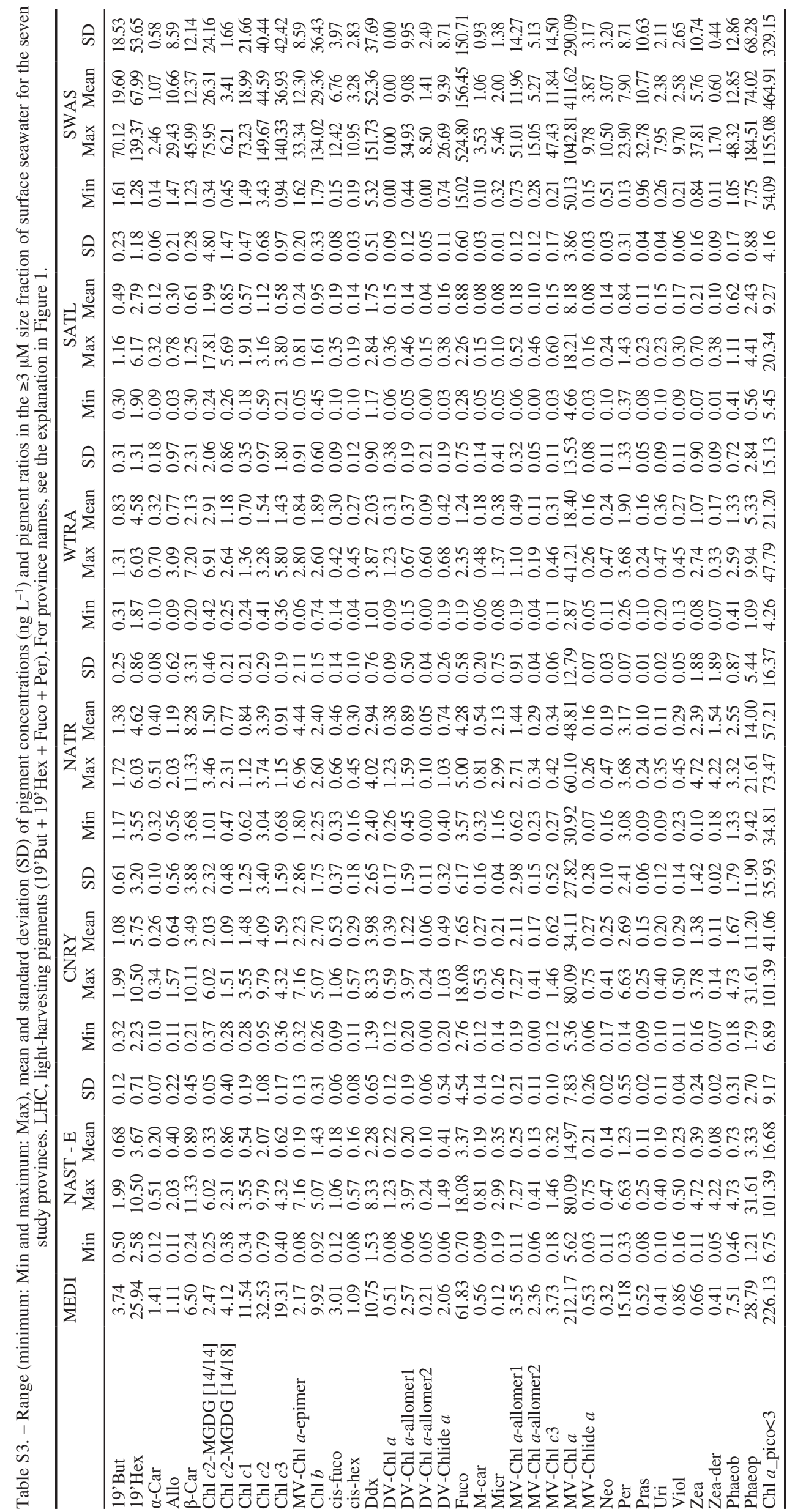




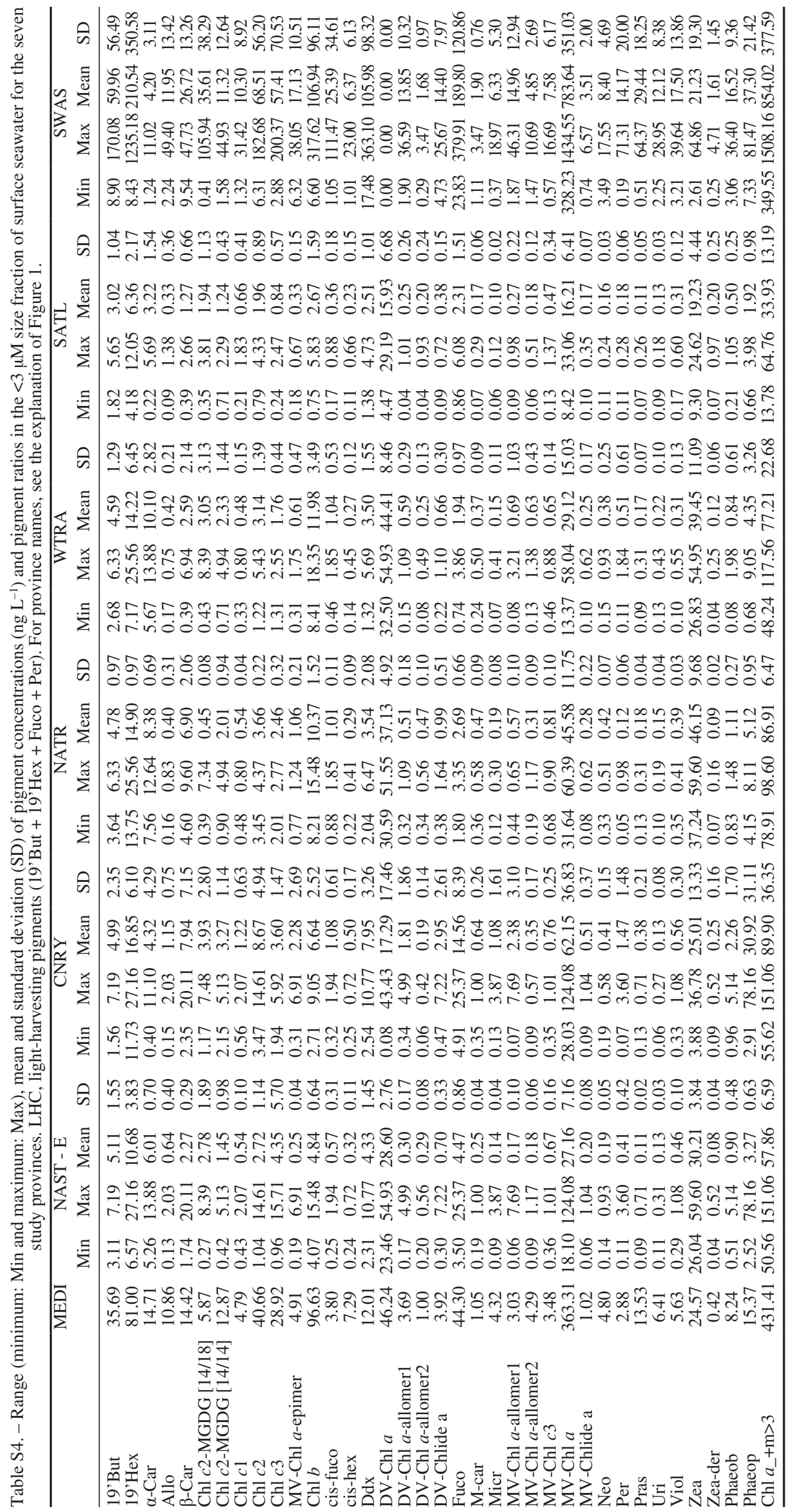




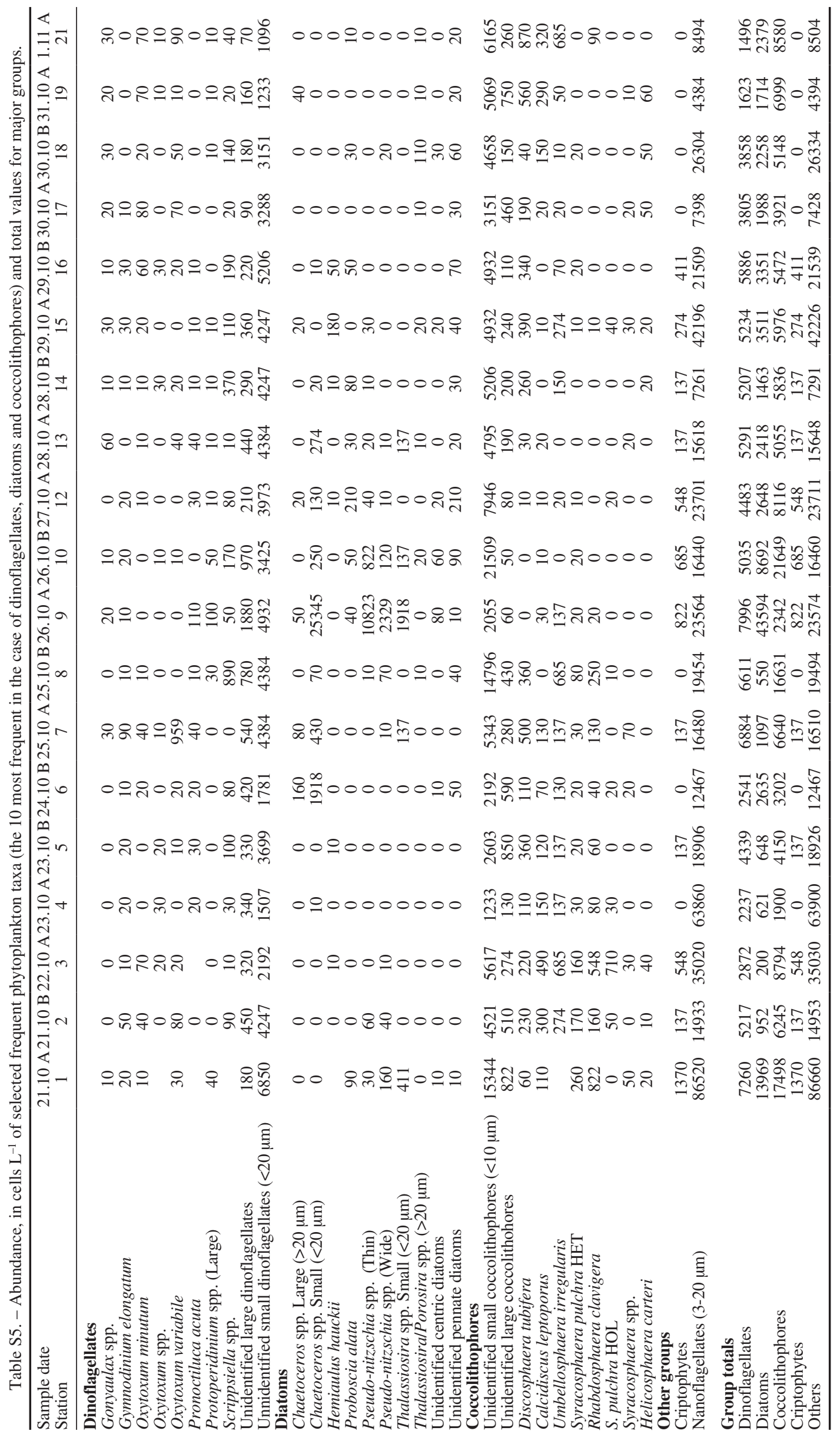




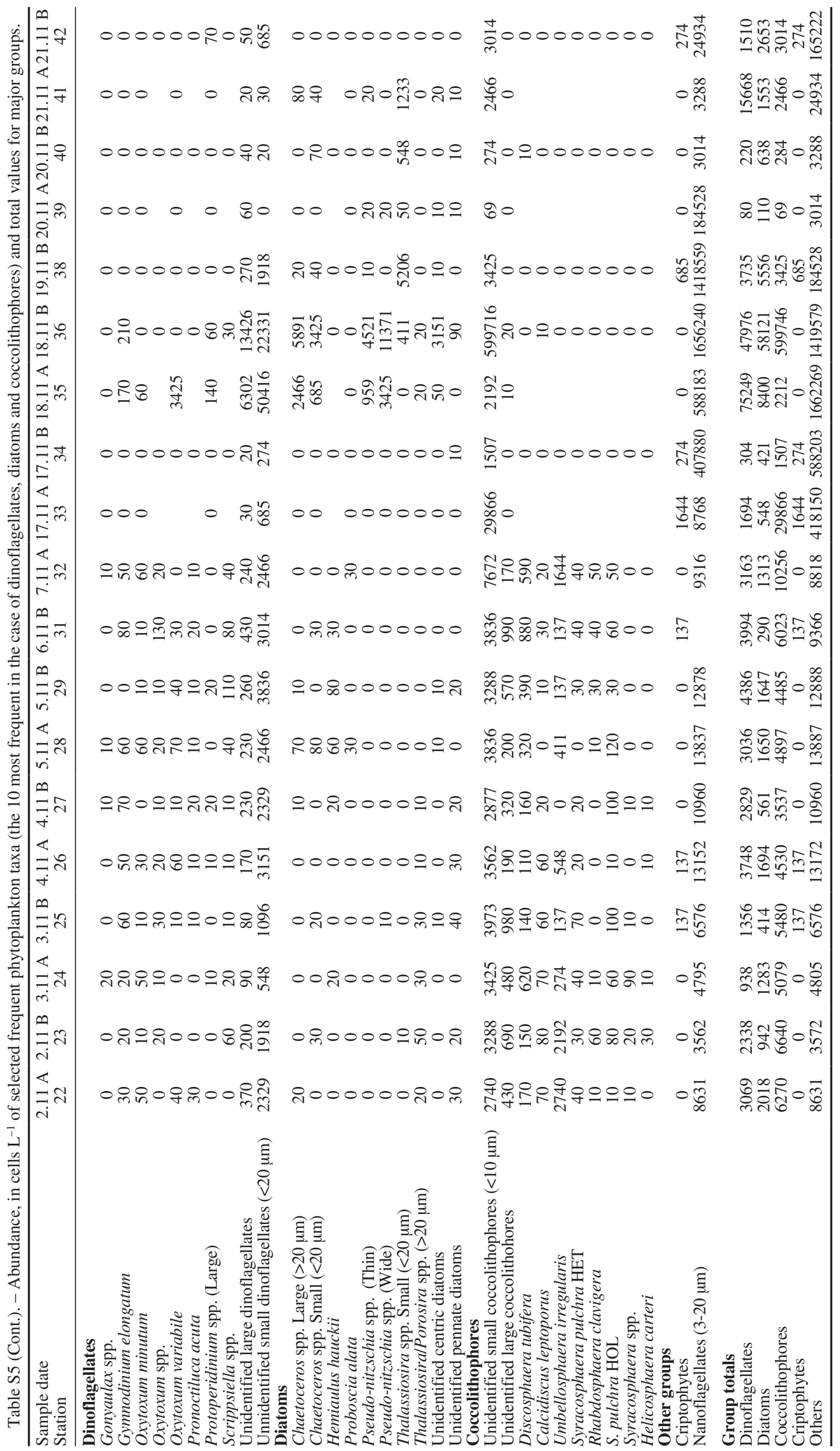


A

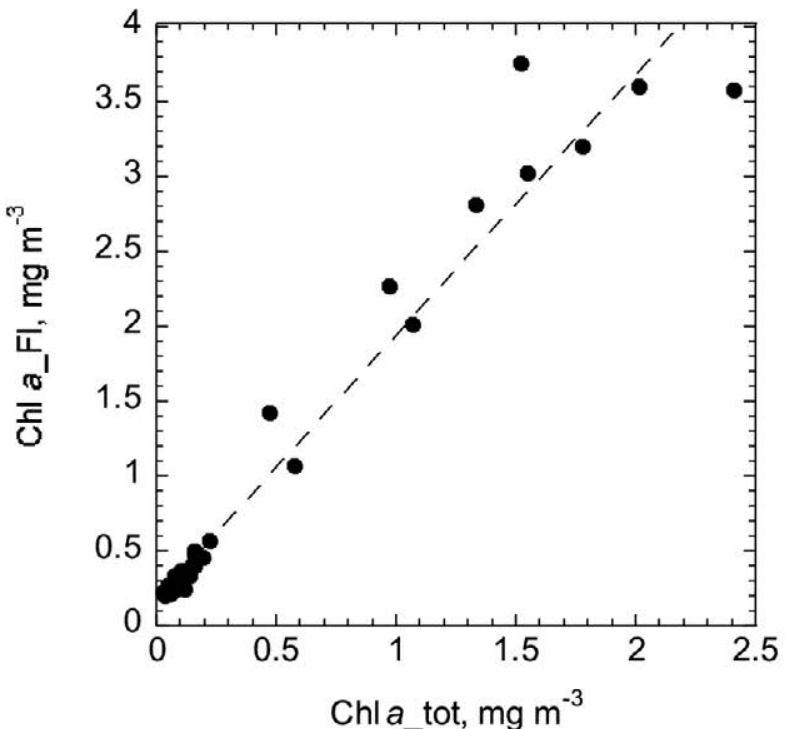

C ○ Chl a_tot $<0.25 \mathrm{mg} \mathrm{m}^{-3} \bullet$ Chl a_tot $>0.25 \mathrm{mg} \mathrm{m}^{-3}$

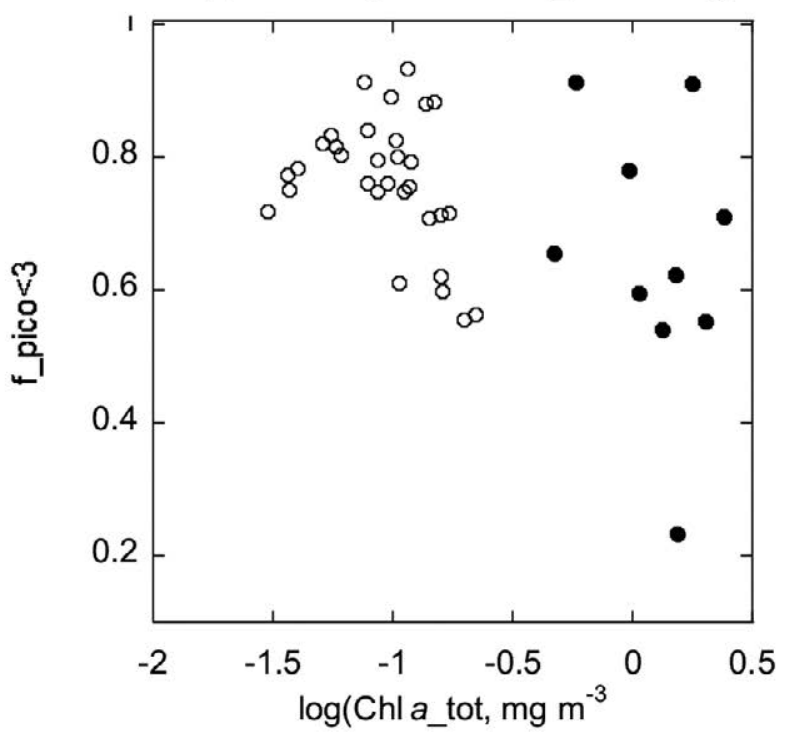

B

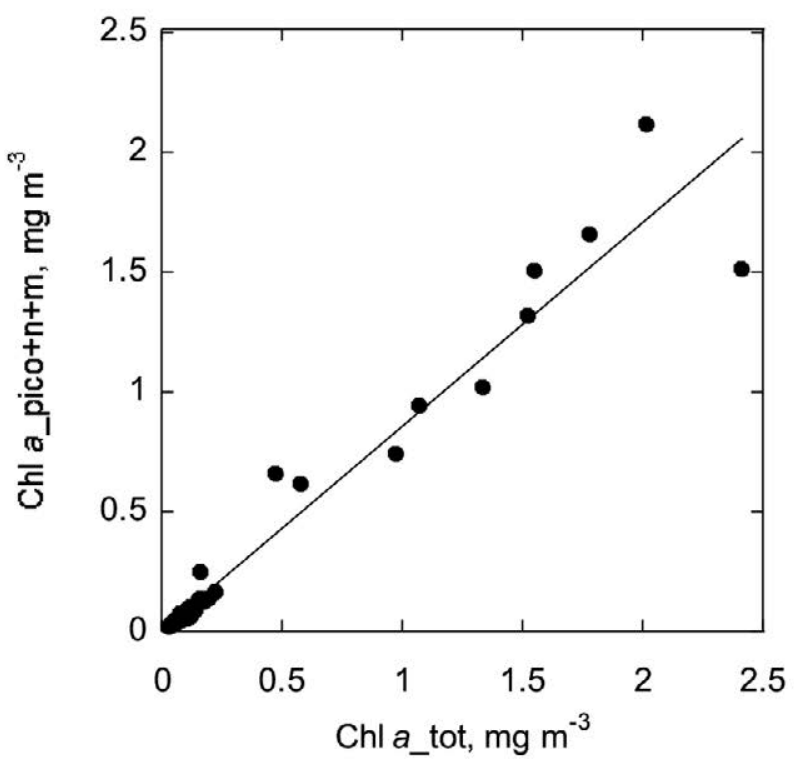

D

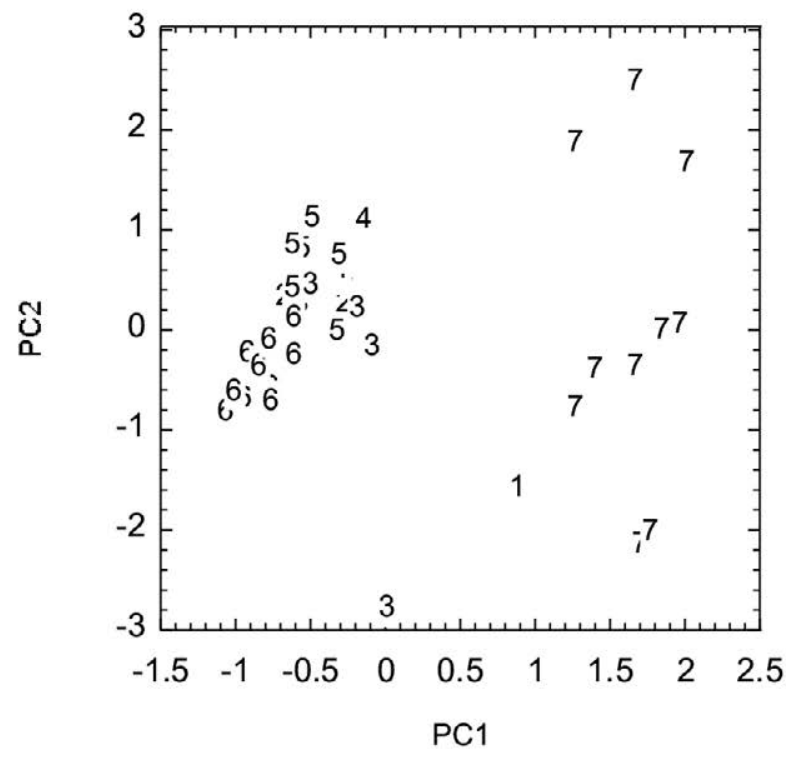

Fig. S1. - A, relationships between regression of Chl $a \_$Fl and Chl $a \_$tot), Chl $a \_\mathrm{Fl}=1.76 * \mathrm{Chl} a$ tot $+0.17, \mathrm{n}=41, \mathrm{r}^{2}=0.96, \mathrm{p}<0.0001$ (one Chl $a$ tot outlier for station 41 was excluded); B, between the sum of the $<3$ (f pico $<3$ ) and the $\geq 3$ (f $n+m \geq 3$ ) Chl $a$ filtration fractions $\left(\mathrm{Chl} a \_\right.$pico $\left.<3+\mathrm{n}+\mathrm{m} \geq 3\right)$ and Chl $a \_$tot, Chl $a_{-}$pico $<3+\mathrm{n}+\mathrm{m} \geq 3=0.85+\mathrm{Chl} a$ _tot $+0.005 ; \mathrm{n}=41, \mathrm{r}^{2}=0.95, \mathrm{p}<0.0001$; the same outlier was also excluded); C, between f_pico<3 and $\log (\mathrm{Chl} a$ tot); D, between PC2 and PC1. The numbers within the graph indicate the provinces (see the explanation of Table S1 for abbreviations). 1, MEDI; 2, NAST-E; 3, CNRY; 4, NATR; 5, WTRA; 6, SATL; 7, SWAS. 


\section{Whole water}
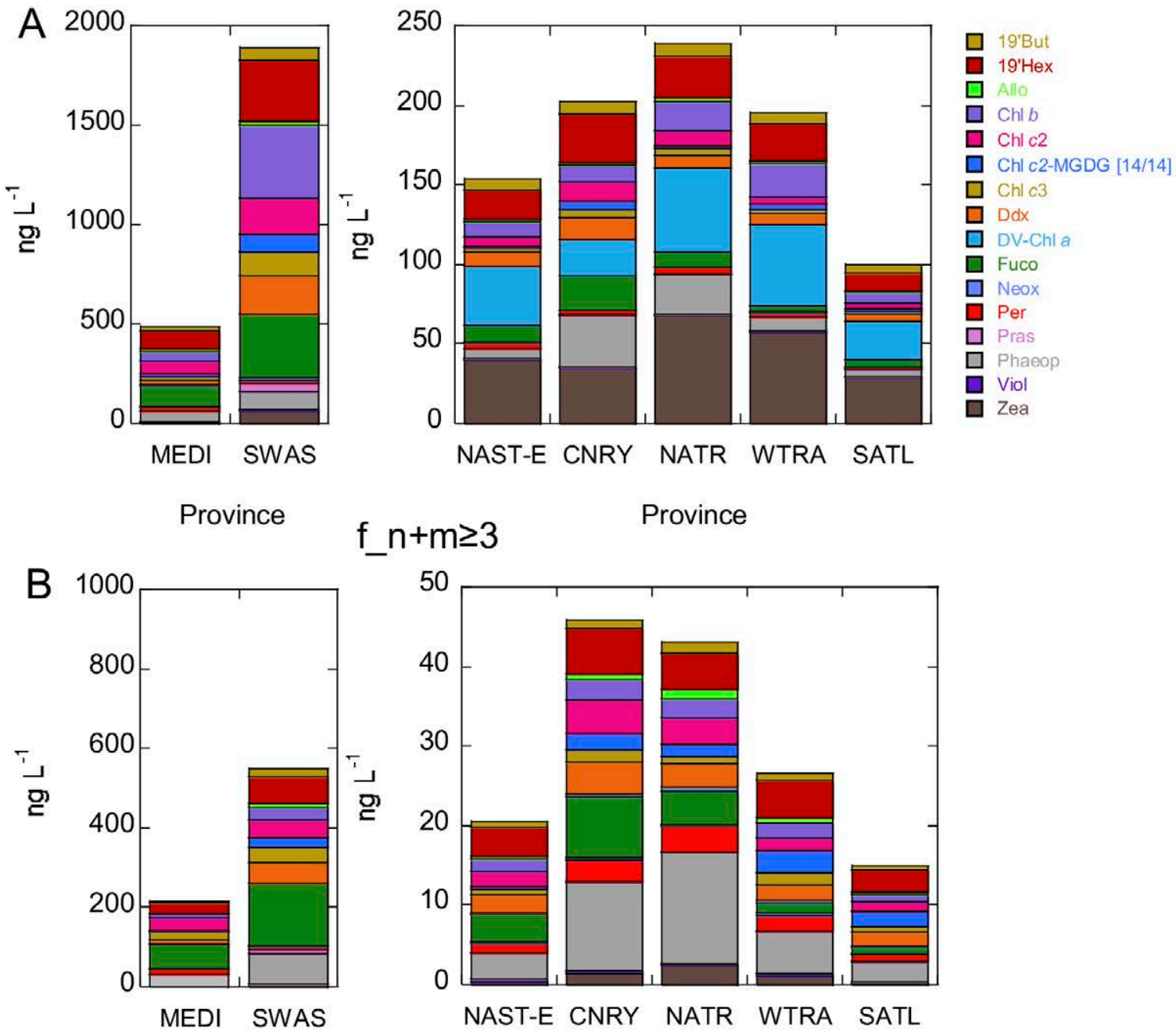

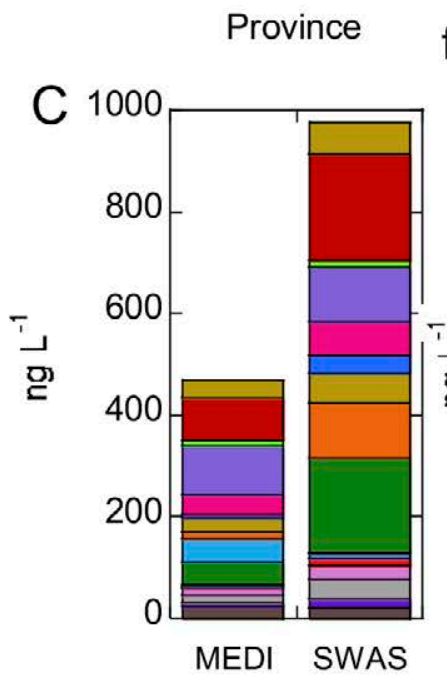

Province

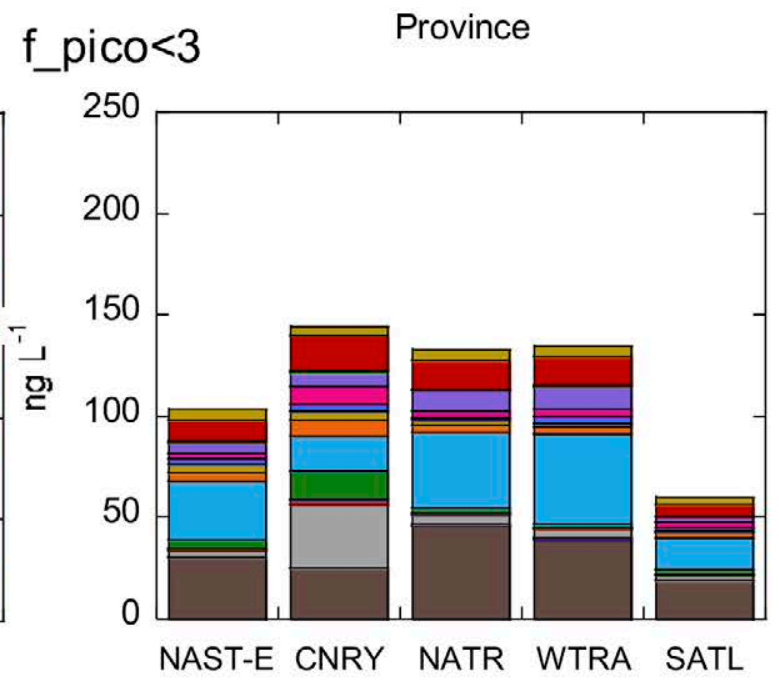

Province

Fig. S2. - Average HPLC-determined concentration of the 11 globally most abundant pigments plus the biomarkers alloxanthin, neoxanthin, peridinin, prasinoxanthin and violaxanthin in the seven provinces for whole water (A), the $f \_n+m \geq 3$ fraction (B) and the $f \_p i c o<3$ fraction (C). Province name abbreviations as in Table S1. Pigment abbreviations as in Table 1. 

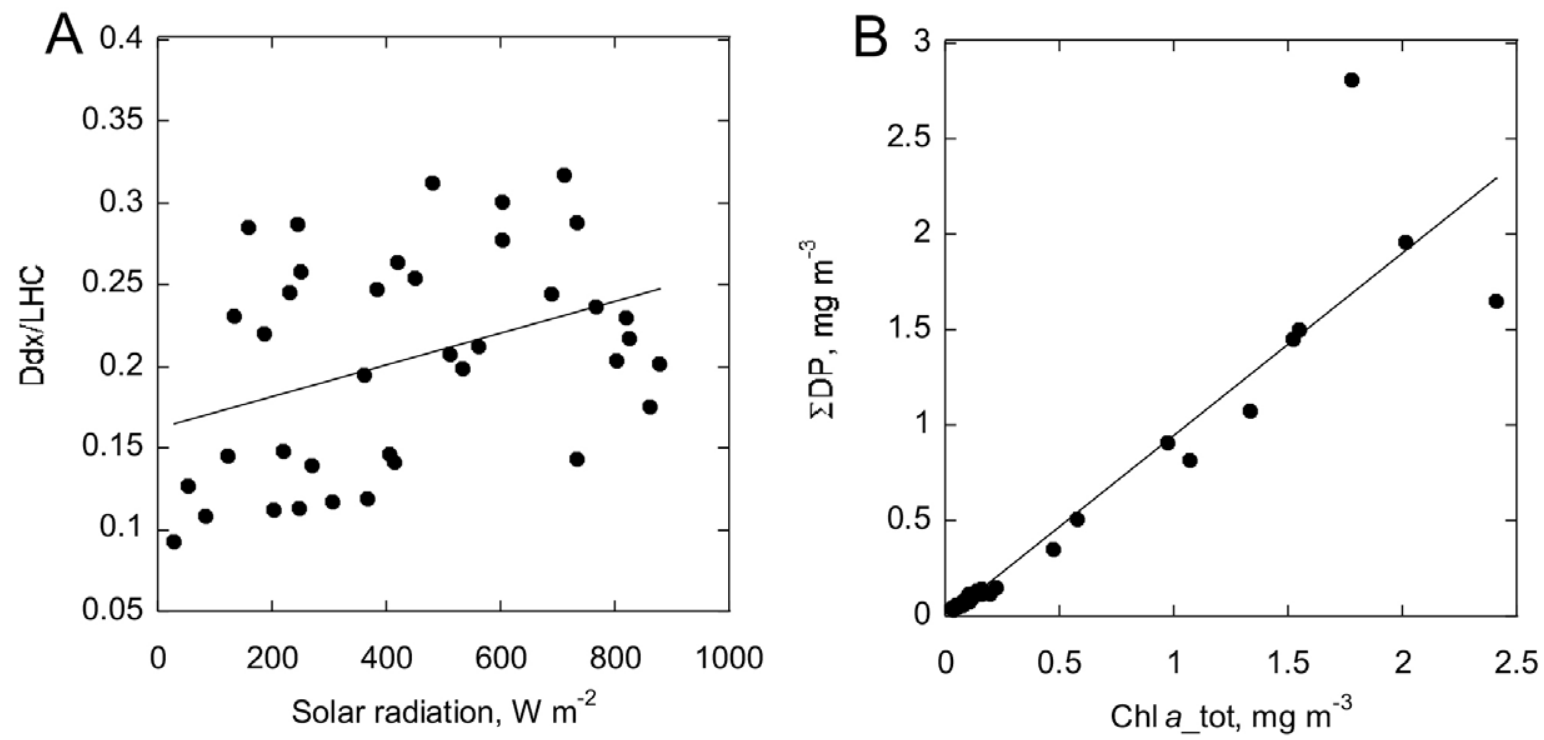

Fig. S3. - A, relationship between Ddx/LSC and solar radiation, $y=9.72 \mathrm{e}-5 * x+0.162, \mathrm{n}=40, \mathrm{r}^{2}=0.14, \mathrm{p}<0.05$; B, between SDP and Chl $a \_$tot, $\mathrm{SDP}=0.96 *$ Chl $a$ _tot $-0.01, \mathrm{n}=41, \mathrm{r}^{2}=0.88, \mathrm{p}<0.0001$.
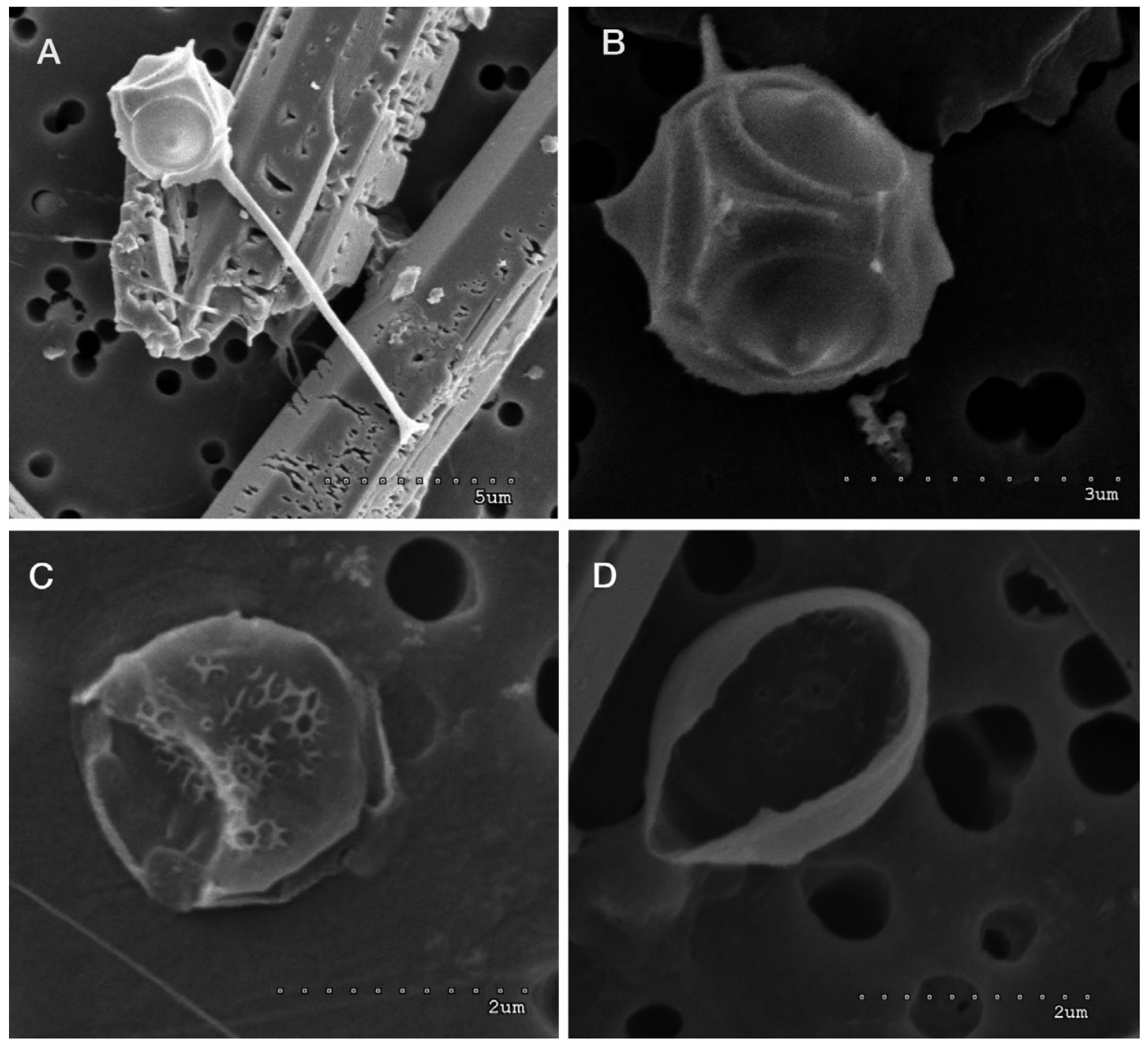

Fig. S4. - Scanning electron micrographs of Triparma laevis (Parmales) (A, B) and Minidiscus sp. (Bacillariophyceae) (C, D). 

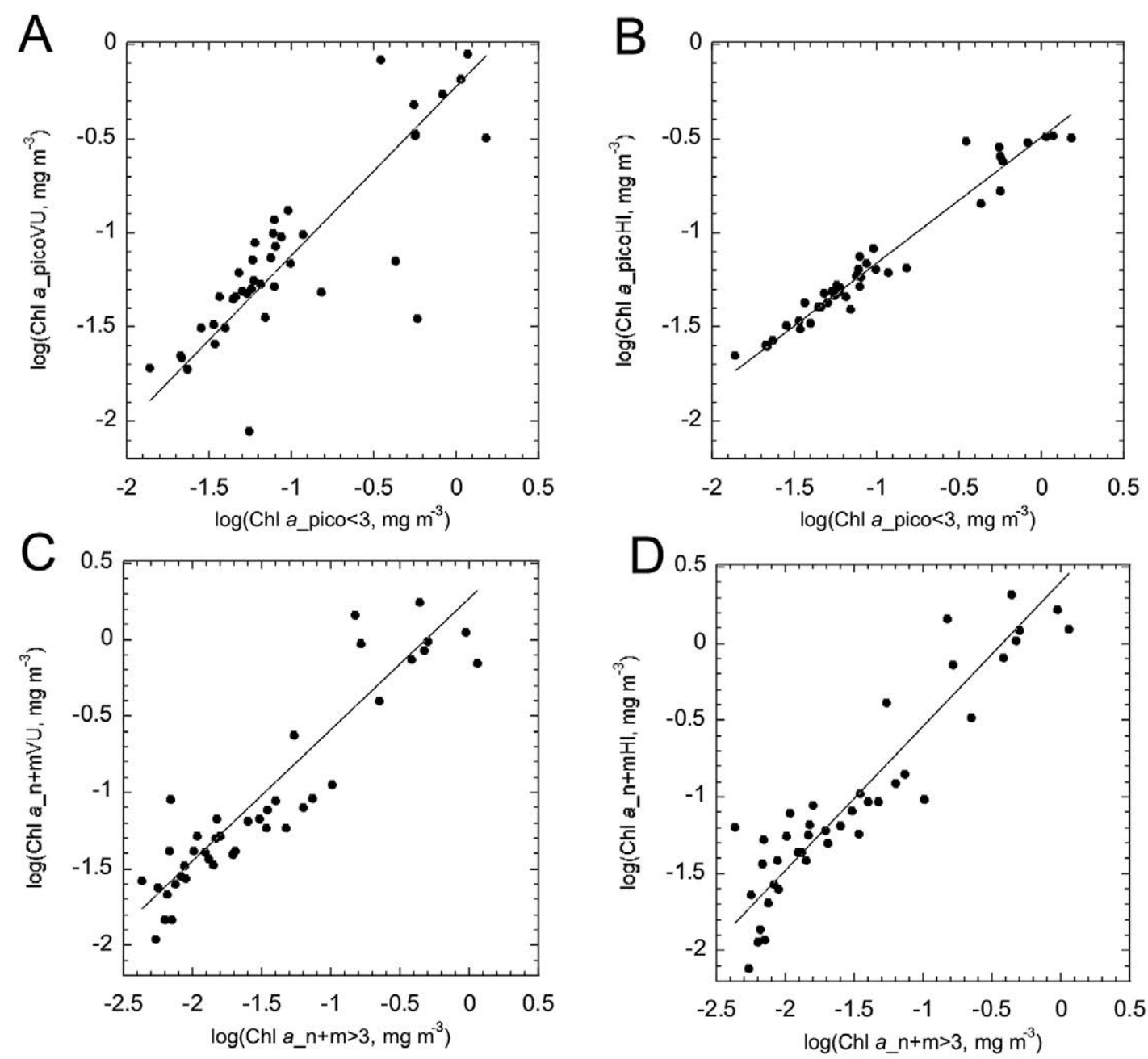

Fig. S5. - A to D, log-log standard major axis regressions of the picoplankton and nano+microphytoplankton contributions to total Chl $a$ (in $\mathrm{mg} \mathrm{m}^{-3}$ ) estimated by the methods of Vidussi et al. (2001)-Uitz et al. (2006) (Chl $a \_p i c o V U$ and Chl $a \_n+m V U$, respectively) and Hirata et al. (2011) (Chl $a$ picoHI and $\mathrm{Chl} a \mathrm{n}+\mathrm{mHI}$, respectively), with the $\mathrm{Chl} a$ pico $<3$ and $\mathrm{Chl} a \mathrm{n}+\mathrm{m} \geq 3$ derived from the filtrations. The equations are (A) $\log \left(\mathrm{Chl} a \_\right.$picoVU $)=0.90 * \log \left(\mathrm{Chl} a \_\right.$pico<3 $)-0.22, \mathrm{n}=41, \mathrm{r}^{2}=0.69, \mathrm{p}<0.0001 ; \mathrm{B}, \log \left(\mathrm{Chl} a \_\right.$picoHI $)=0.67 * \log \left(\mathrm{Chl} a \_\right.$pico $\left.<3\right)-$ $0.49, \mathrm{n}=41, \mathrm{r}^{2}=0.95, \mathrm{p}<0.0001 ; \mathrm{C}, \log \left(\mathrm{Chl} a \_\mathrm{n}+\mathrm{mVU}\right)=0.89 * \log \left(\mathrm{Chl} a \_\mathrm{n}+\mathrm{m} \geq 3\right)+0.27, \mathrm{n}=41, \mathrm{r}^{2}=0.86, \mathrm{p}<0.0001 ; \mathrm{D}, \log \left(\mathrm{Chl} a \_\mathrm{n}+\mathrm{mHI}\right)=$ $0.94 * \log \left(\mathrm{Chl} a \_\mathrm{n}+\mathrm{m} \geq 3\right)+0.40, \mathrm{n}=41, \mathrm{r}^{2}=0.86, \mathrm{p}<0.0001$. In A, C and D the slopes were not statistically different from 1 .
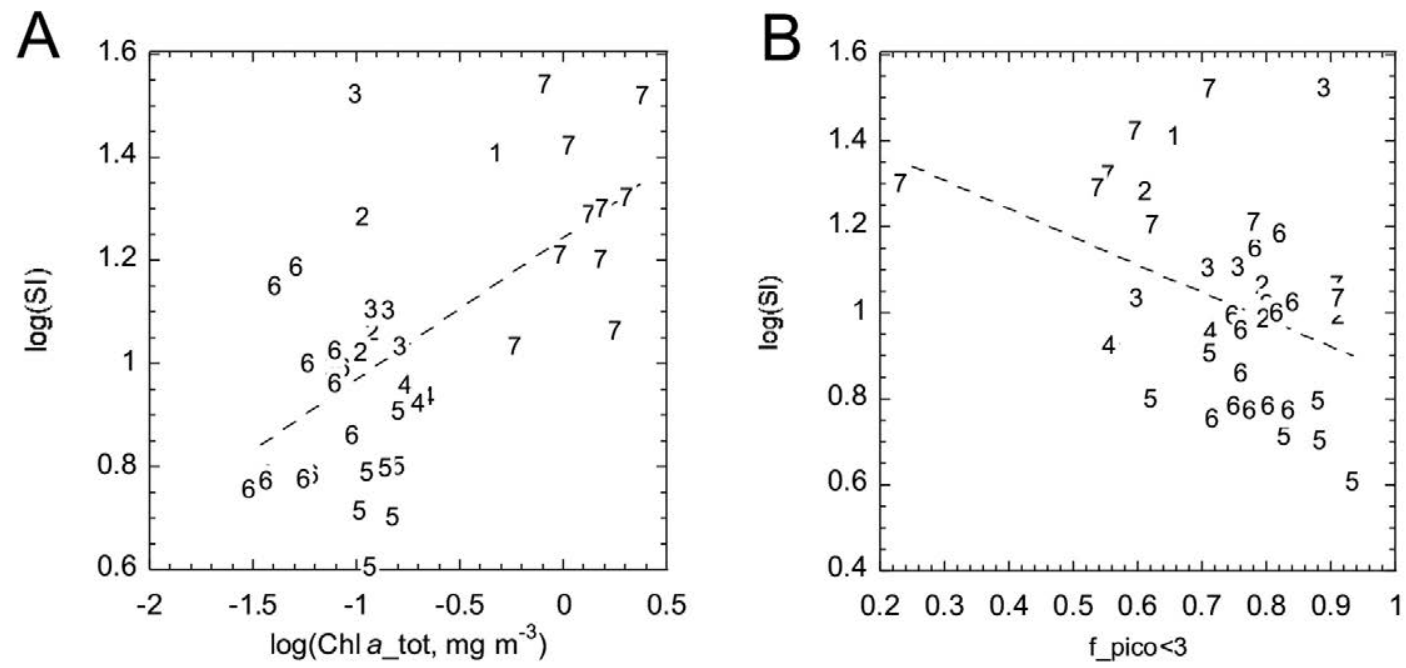

Fig. S6. - A, regression of the logarithm of the size index (SI) on $\log \left(\mathrm{Chl} a \_\right.$tot $)\left[\log (\mathrm{Si})=0.28 * \log \left(\mathrm{Chl} a \_\right.\right.$tot $)+1.24, \mathrm{n}=41, \mathrm{r}^{2}=0.38$, $\mathrm{p}<0.0001]$; and $\mathrm{B}$, of the logarithm of the size index $(\mathrm{SI})$ on $\mathrm{f} \_$pico $<3\left[\log (\mathrm{Si})=-0.65 * \mathrm{f} \_\mathrm{pico}<3+1.50, \mathrm{n}=41, \mathrm{r}^{2}=0.14, \mathrm{p}<0.05\right]$. The numbers within the graph indicate the provinces (see the explanation of Table S1 for abbreviations). 1, MEDI; 2, NAST-E; 3, CNRY; 4, NATR; 5, WTRA; 6, SATL; 7, SWAS. 

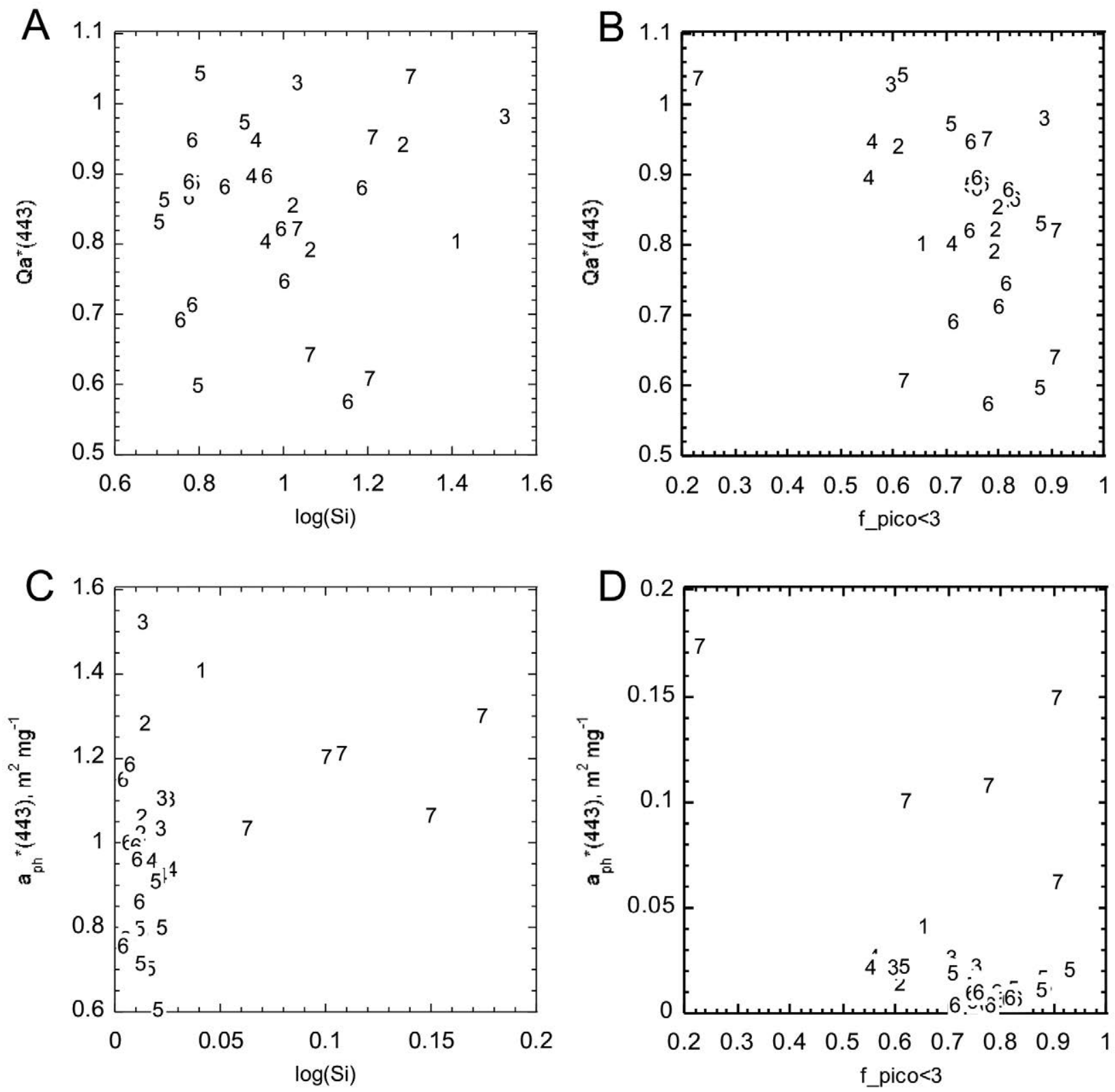

Fig. S7. - A, relationships between $\mathrm{Q} a *(443)$ and $\log (\mathrm{Si}) ; \mathrm{B}$, between $\mathrm{Qa} *(443)$ and the proportion of Chl $a$ in the $<3$ um fraction of the filtrations (f_pico<3); C, between $\mathrm{a}_{\mathrm{ph}} *(443)$ and $\log (\mathrm{Si})$; and $\mathrm{D}$, between $\mathrm{a}_{\mathrm{ph}} *(443)$ and $\mathrm{f} \_$pico<3. The numbers within the graph indicate the provinces (see the explanation of Table S1 for abbreviations). 1, MEDI; 2, NAST-E; 3, CNRY; 4, NATR; 5, WTRA; 6, SATL; 7, SWAS. 


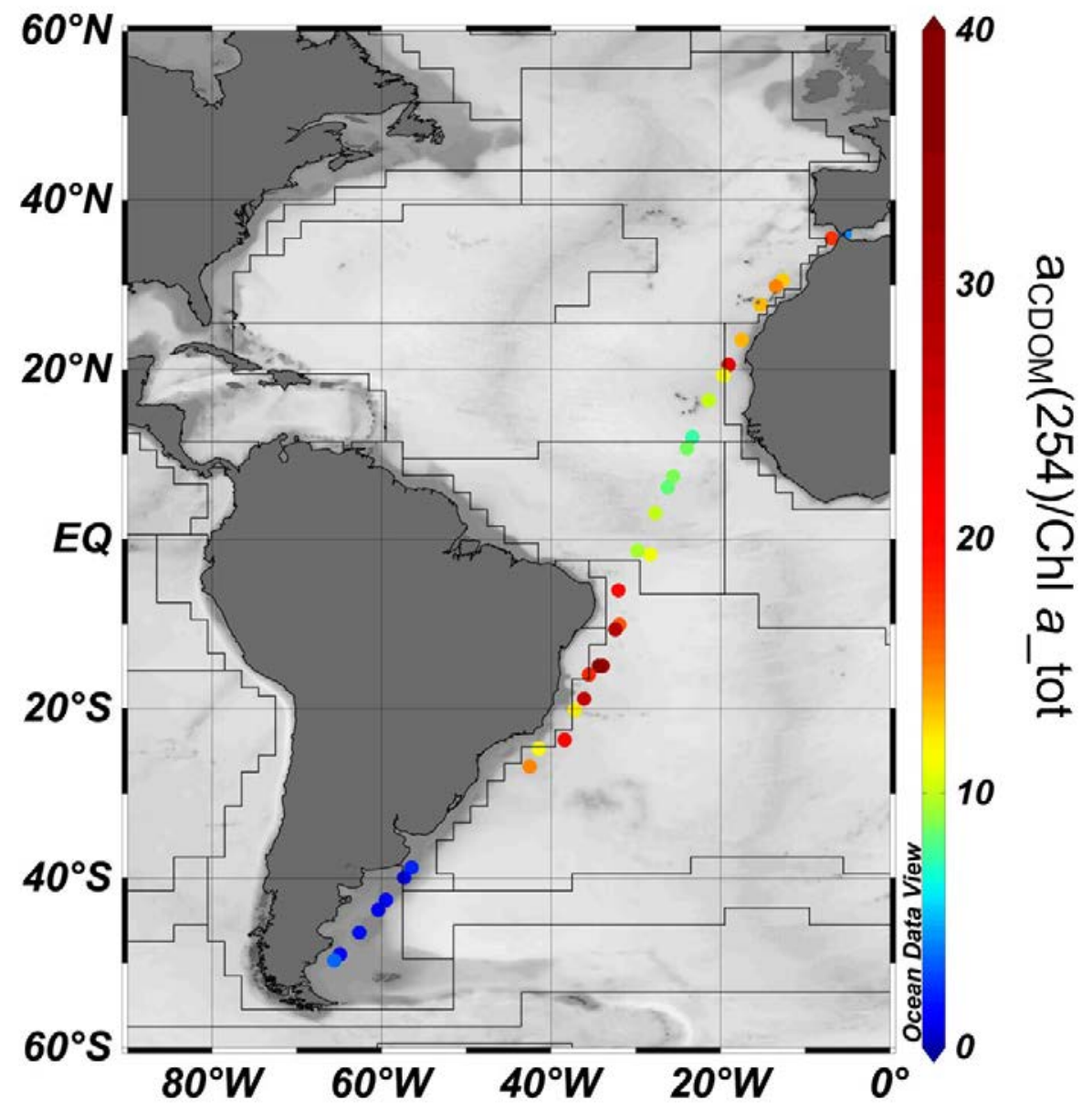

Fig. S8. - Geographic distribution of the ratio $\mathrm{a}_{\mathrm{CDOM}}(254) / \mathrm{Chl} a_{-}$tot (units are $\mathrm{m}^{-1}$ and $\mathrm{mg} \mathrm{m}^{-3}$, respectively). The lines indicate province limits, as in Figure 1. 